INTER NATIONAL MONETARY FUND

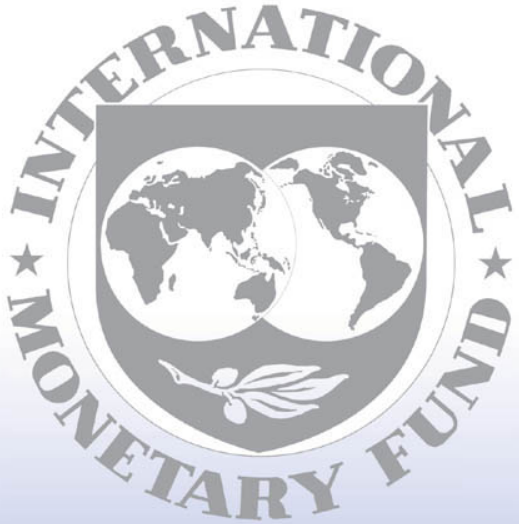

Staff

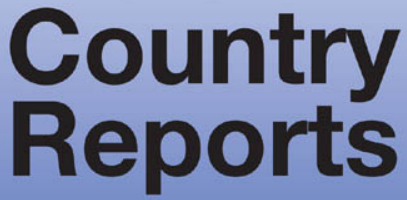




\section{Republic of Tajikistan: Poverty Reduction Strategy Paper Progress Report}

Poverty Reduction Strategy Papers (PRSPs) are prepared by member countries in broad consultation with stakeholders and development partners, including the staffs of the World Bank and the IMF. Updated every three years with annual progress reports, they describe the country's macroeconomic, structural, and social policies in support of growth and poverty reduction, as well as associated external financing needs and major sources of financing. This country document for the Republic of Tajikistan, dated March 2004, is being made available on the IMF website by agreement with the member country as a service to users of the IMF website.

To assist the IMF in evaluating the publication policy, reader comments are invited and may be sent by e-mail to publicationpolicy@imf.org.

Copies of this report are available to the public from

International Monetary Fund • Publication Services

$70019^{\text {th }}$ Street, N.W. • Washington, D.C. 20431

Telephone: (202) 623-7430 • Telefax: (202) 623-7201

E-mail: publications@imf.org •Internet: http://www.imf.org

Price: $\$ 15.00$ a copy

\section{International Monetary Fund \\ Washington, D.C.}


This page intentionally left blank

(C)International Monetary Fund. Not for Redistribution 


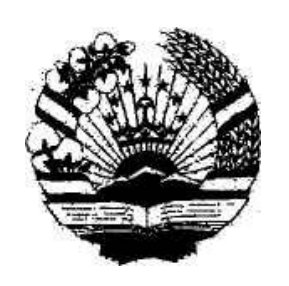

GOVERNMENT OF THE REPUBLIC OF TAJIKISTAN

\section{PRSP}

\section{First Progress Report}

DUSHANBE -MARCH 2004

CInternational Monetary Fund. Not for Redistribution 


\section{ABBREVIATIONS:}

\begin{tabular}{|c|c|}
\hline $\mathrm{ACU}$ & Aid Coordination Unit \\
\hline $\mathrm{ADB}$ & Asian Development Bank \\
\hline $\mathrm{CSO}$ & Civil Society Organizations \\
\hline DOTS & Directly Observed Therapy Strategy \\
\hline EBRD & European Bank for Reconstruction and Development \\
\hline GBAO & Gorno-Badakshan Autonomous Oblast \\
\hline GDP & Gross Domestic Product \\
\hline GRT & Government of Republic of Tajikistan \\
\hline HIV/AIDS & Human Immuno-Deficiency Virus/Acquired Immuno-Deficiency Syndrome \\
\hline HPS & Hydro-Power Station \\
\hline IDB & Islamic Development Bank \\
\hline ILO & International Labor Organization \\
\hline $10 \mathrm{M}$ & International Organization of Migration \\
\hline MDG & Millennium Development Goals \\
\hline MOE & Ministry of Education \\
\hline MOET & Ministry of Economy and Trade \\
\hline MOF & Ministry of Finance \\
\hline $\mathrm{MOH}$ & Ministry of Health \\
\hline MLSP & Ministry of Labor and Social Protection \\
\hline MSRD & Ministry of State Revenues and Duties \\
\hline MTBF & Medium-term Budget Framework \\
\hline NBT & National Bank of Tajikistan \\
\hline NGO & Non-Governmental Organizations \\
\hline NNWSS & National Nutrition and Water and Sanitation Survey \\
\hline NSIFT & National Social Investment Fund of Tajikistan \\
\hline PHC & Primary Health Care \\
\hline PIP & Public Investment Program \\
\hline PPP & Purchasing Power Parity \\
\hline PRGF & Poverty Reduction and Growth Facility \\
\hline PRSP & Poverty Reduction Strategy Paper \\
\hline PRSPMD & PRSP Monitoring Department \\
\hline RRS & Regions of Republican Subordination \\
\hline SAC & Structural Adjustment Credit \\
\hline $\mathrm{SSC}$ & State Statistics Committee \\
\hline SFCC & State Financial Control Committee \\
\hline SLMC & State Land Management Committee \\
\hline TADAZ & Tajik Aluminum Factory \\
\hline TLSS & Tajik Livings Standards Survey \\
\hline UNDP & United Nations Development Programme \\
\hline UNICEF & United Nations Children's Fund \\
\hline VAT & Value-added Tax \\
\hline WB & World Bank \\
\hline WHO & World Health Organization \\
\hline
\end{tabular}




\section{Table of Contents:}

\section{Abbreviations}

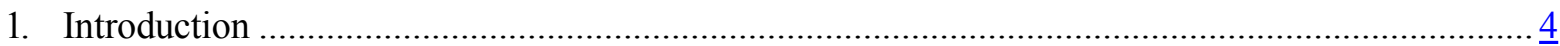

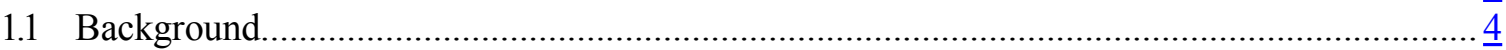

1.2 Highlights of performance of implementing PRSP compared to targets ................................ $\overline{5}$

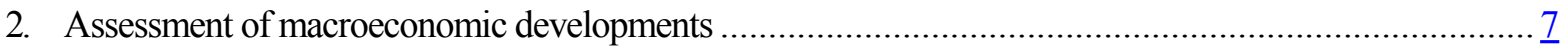

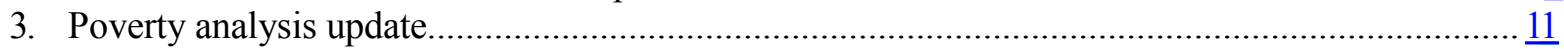

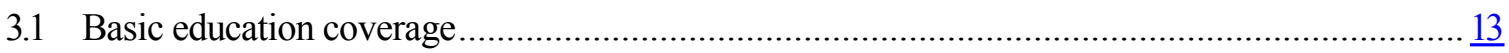

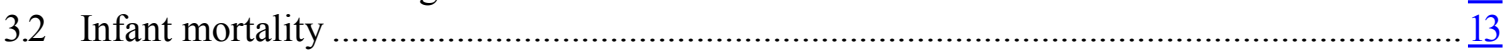

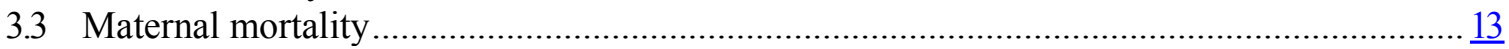

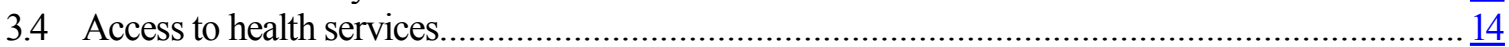

3.5 Access to safe water............................................................................ $\frac{14}{14}$

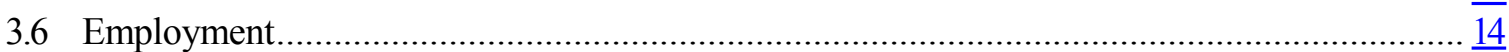

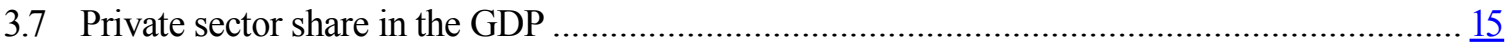

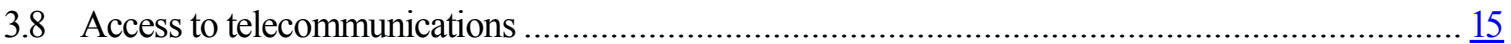

4. PRSP policy implementation: 2002-2003 ............................................................................ $\frac{15}{15}$

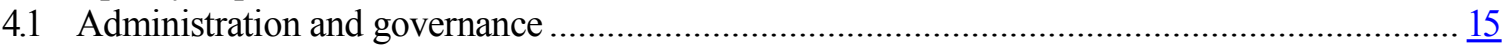

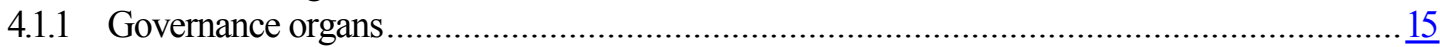

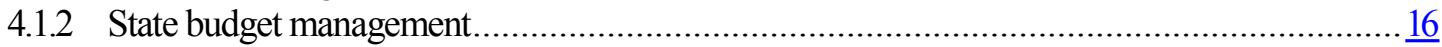

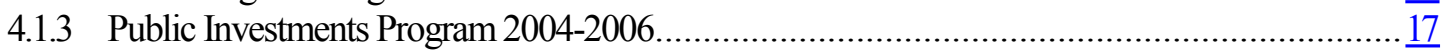

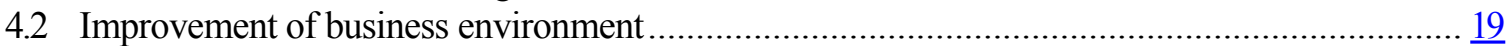

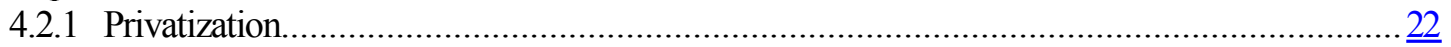

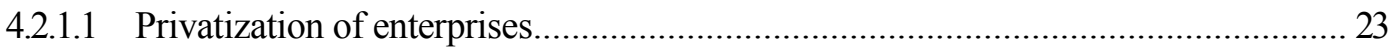

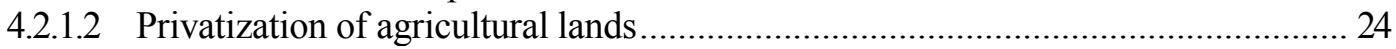

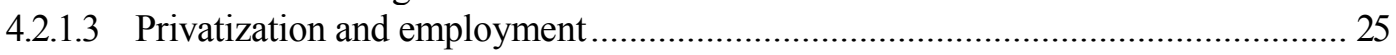

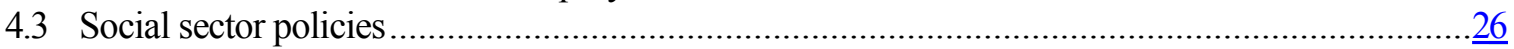

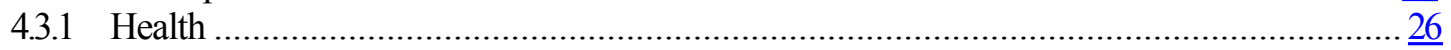

4.3.2 Education ................................................................................. $\frac{28}{28}$

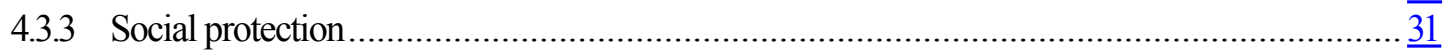

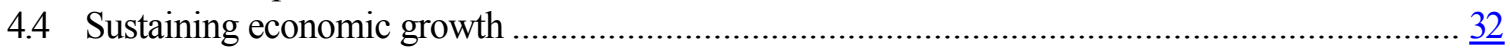

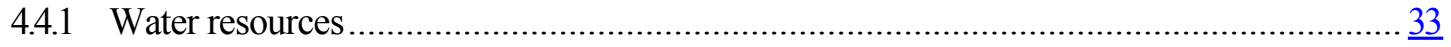

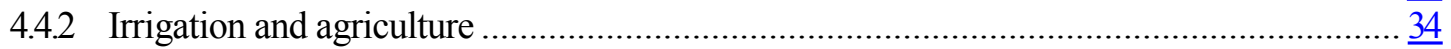

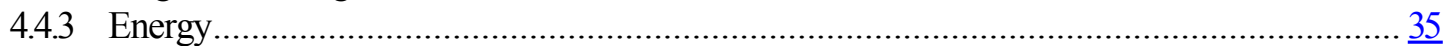

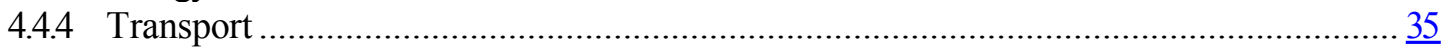

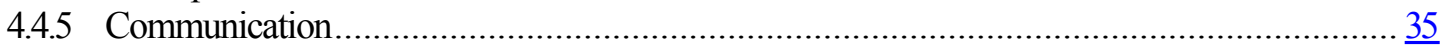

4.5 Environmental protection...................................................................................

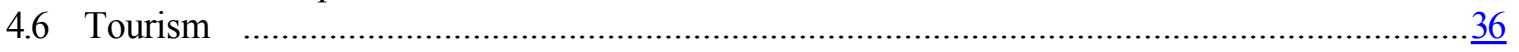

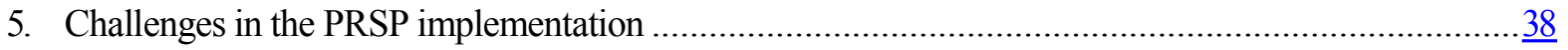

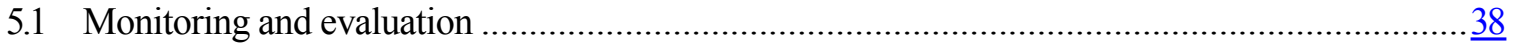

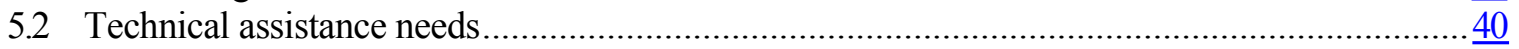

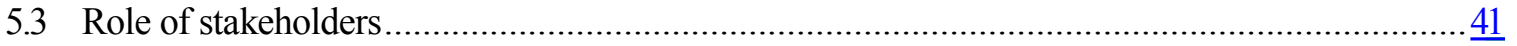

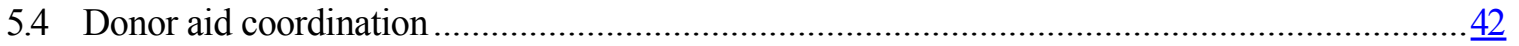




\section{ATTACHMENTS:}

ATTACHMENT 1. Matrix of GRT Policies for Poverty Reduction..................................................43

ATTACHMENT 2. Matrix of legal base for PRSP implementation .............................................. $\frac{54}{59}$

ATTACHMENT 3. Surveys used in the PRSP Progress Report......................................................

\section{TABLES:}

Table 1: Poverty reduction targets based on MDG

Table 2. General Macroeconomic Indicators, 1999-2003

Table 4. Expenditures by Economic Type, 2002-2003 (\% GDP) …….............................................. $\underline{8}$

Table 5. Medium-term budget framework, 2004-2006 .................................................................... 10

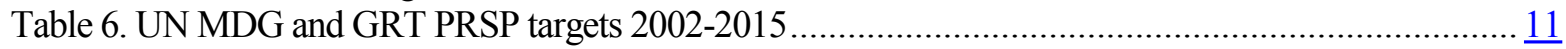

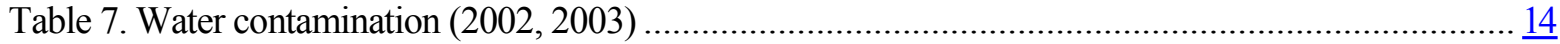

Table 8. PIP 2004-2006 by sector (USD mill.)......................................................................... 18

Table 9. Grants and Technical Assistance Program, PIP 2004-2006 by sector (USD thou.)................... 19

Table 10. Number of businesses established 2000-2003 ............................................................... 20

Table 11. Enterprise privatizations (as of August 2003) ........................................................... $\underline{23}$

Table 12. State Employment Program of MLSP (2002) …................................................................ $\underline{25}$

Table 13. Female students admitted to higher educational institutions under Presidential

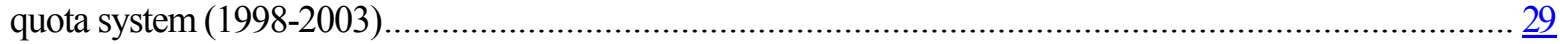

Table 14. Average wages and average pensions, (1999-2003) .......................................................... $\underline{32}$

Table 15. Foreign visitors in Tajikistan (1996-2003) ........................................................................ $\frac{37}{41}$

Table 16. Televised hotline conferences $(2001-2003)$........................................................................ 41

\section{FIGURES:}

Figure 1. PRSP Monitoring Department in the GRT (2003) ........................................................... $\underline{39}$

Figure 2. Coordination of institutions for PRSP monitoring........................................................... 40 


\section{Introduction}

\subsection{Background}

The Government of Republic of Tajikistan had committed itself to Poverty Reduction Strategy Paper (PRSP) in June 2002. The purpose of this First Progress Report is to inform on the progress in PRSP implementation and progress in poverty reduction. It is expected that the Report will be used as a tool to better coordinate the implementation of PRSP and as a basis for continued cooperation with the donor community. The Report assesses the activities for the period between the approval of the PRSP by the Parliament in June 2002 and the end of 2003. The Report notes that the poverty situation has improved, details the progress made in key sectors and highlights constraints. It also notes that, the most significant challenges relate to the acceleration of implementation in the context of privatization, land reform, and improvement of private business environment. The outstanding need to strengthen the institutional capacity to implement reforms is a subtext throughout the report.

The original PRSP objectives were to increase the real incomes of the people, achieve fair distribution of the benefits of growth and ensure a rise in the living standards of the poorest groups of the population. The main elements in the strategy are:

- Accelerated, labor-intensive, export-oriented, and socially-fair economic growth,

- Fair and efficient provision of basic social services,

- Targeted support to the poorest groups of the population, and

- Efficient governance and improved security.

To achieve progress in these four elements for reducing poverty, the GRT adopted sector policies and actions, which focused on education, health, and social protection; agriculture; privatization, labor and private sector development; infrastructure and communication; environmental protection and tourism. During the reporting period, the GRT has used the matrix of activities for the first implementation year of PRSP (Attachment 1). This matrix is based on the original PRSP matrix.

The GRT is encouraged with the reception given to the implementation of the PRSP at the May 2003 Consultative Group Meeting of Donors and at the Follow-up meetings during November 2003 and February 2004. Measures to improve institutions, such as maintaining peace and stability, reforming the banking system, and improving the functions of the public services were seen as making important contributions to economic growth and equity. Implementation of poverty reduction policies requires working closely with development partners. Progress has been made to improve aid coordination and aid absorption. However, significant difficulties remain in the full realization of aid delivery and aid absorption. The responsibility for implementation of policies lies with the GRT and the donor partners. The GRT, faced with the very complex issues of poverty, recognizes that increasing levels of efforts are needed to achieve development goals.

During the reporting period, the GRT has attended to some of the initial measures of poverty reduction policies. These included further defining the prioritization of policies, creation of various policy implementing organizations and expanding the basic legal infrastructure and administrative procedures. Attachment 2 summarizes the legal framework, on which the Government has been building the foundation of institutionalization of the poverty reduction policies. These initial measures may become the building blocks for the next stages of poverty reduction work if the currently observed difficulties are managed well by the time the PRSP Second 
Progress Report is prepared. Before then, a strategic and a comprehensive management of the entire process will be put in place. The practical implementing process will be broadened with involvement of more stakeholder groups and by increased information base. The implementation of the existing legislation also gains a much more fundamental role.

These are institution building activities. Their realization requires determination, time and resources. Among the GRT actions, to deepen the poverty reduction strategies (PRS) policies in the next cycle, the following are proposed. The number of organizations for data collection and analyses will be increased and given a voice in public forums. The Parliament, media, and CSOs will be able to more easily enlist and to participate in the implementation of the PRSP process. The capacity of the judiciary and legislature will be increased. In addition, the Government recommits itself to sustaining the ongoing policies of macroeconomic stability, private sector growth, agricultural reforms, and increased and targeted spending in social sectors. The donor community is expected to participate with the GRT in these particular areas of poverty reduction policies through grants and other technical assistance.

\subsection{Highlights of performance of implementing PRSP compared to targets}

To be able to measure progress in poverty reduction, the GRT has chosen a number of poverty indicators and set itself specific quantitative targets to be achieved for each of the indicators within a certain period of time. In the selection of indicators, the GRT adopted some that were established as part of the Millennium Development Goals by the United Nations Organization. Table 1 shows the indicators for Tajikistan and the targets to be reached.

Table 1: Poverty reduction achievements based on MDG.

\begin{tabular}{|l|c|c|c|c|}
\hline \multicolumn{1}{|c|}{ Indicators } & 2001 & $\begin{array}{c}2003 \\
\text { Achievements }\end{array}$ & $\begin{array}{c}2006 \\
\text { Targets }\end{array}$ & $\begin{array}{c}2015 \\
\text { Targets }\end{array}$ \\
\hline $\begin{array}{l}\text { \% of the population living below the poverty } \\
\text { level }\end{array}$ & 83 & 68 & 75 & 60 \\
\hline Basic education coverage (\%) & 77.7 & $79.1 *$ & 82 & 90 \\
\hline Infant mortality per 1000 live births & 36.7 & 16.7 & 32 & 25 \\
\hline Maternal mortality per 100 000 live births & 43.1 & 45.0 & 40 & 35 \\
\hline $\begin{array}{l}\text { \% of adult population having access to health } \\
\text { services }\end{array}$ & 21.8 & $\mathbf{n . a .}$ & 24 & 30 \\
\hline $\begin{array}{l}\text { Private sector share in the GDP } \\
\text { \% of the population having access to safe }\end{array}$ & 31.2 & $32 * *$ & 40 & 60 \\
\hline drinking water & & 57 & 58 & 80 \\
\hline $\begin{array}{l}\text { Employment rate } \\
\text { Telephones per 100 persons }\end{array}$ & 3.6 & 3.8 & 4 & 5 \\
\hline
\end{tabular}

* Official statistic based on live birth definition other than accepted by WHO. ** For 2002.

The implementation of broad set of PRSP policies has had a tentative beginning. The PRS policies of the GRT remain a multiple-sector approach. The broad approach emphasizes private sector development, which includes reducing government intervention and completing the 
privatization of state-owned enterprises and of farms, reducing quasi-fiscal deficits in energy sector, improving governance, and rationalizing and rehabilitating infrastructure,

The economic growth since 2000 has been strong and real GDP has increased annually on average by 9.5 percent. This real growth has had an impact on reducing overall poverty despite some indications that there is increased income inequality. Even though the per capita income is very low, it has risen in real terms since 2000.

There are positive signs in the initial implementation stages of the PRS process. The national budget remains within the macroeconomic framework of our agreements with the multilateral donor programs (PRGF, SAC). The revenue performance has improved and expenditures are managed with tight fiscal discipline. The expenditures in the social sectors were almost $43 \%$ of the budget in 2003. Cash compensations, increased public sector salaries and increased pensions have targeted social sector spending better. The cash compensations were 12 million Sm. in 2003 budget. This will be increased to 20 million Sm. in the 2004 budget. The budget deficits have declined since 2000 and in 2003 there was a budget surplus. The external borrowing is limited only to the Government's public investment programs in light of the debt burden. Improved financial intermediation and financial infrastructure for micro enterprises are helping private sector economic activities to develop. Increased tariffs for electricity and gas are reducing quasi-fiscal deficits. The Government policies compensate the very poor, who are most adversely affected by these tariff increases, to alleviate the burden. A Department in the President's Executive Offices was established to monitor and regularly report on poverty reduction developments.

The GRT acknowledges that the pace and the depth of the implementation of PRSP reforms have been below the level of initial expectations. In public expenditure management, the links between PRSP and the state budget are weak. The creation of a strategic policy group such as a Budget Commission would provide the institutional framework to implement the medium-term budget framework (MTBF). The budget's current expenditures and capital investments are not yet fully prioritized according to the PRSP. The MTBF for the budget is not yet implemented. The proposed Public Investment Program 2004-2006 is within the external borrowing limit of 3\% of GDP only for 2004. The GRT will revise annual external borrowing levels in accordance with the changing economic conditions. The broader participation of and the accountability to the stakeholders in the use of public funds remain elusive. However, the GRT has taken measures to increase transparency in budget execution, transparency in privatizations, transparency in public procurement, and to improve the standards of auditing institutions. The reasons for the slow adjustment to structural reforms are various. The existing legislations, which were designed in the service of PRSP, are not enforced well and remain, in general, ineffective. The lack of fin $\sim$ cial resources required in the broad approach to all policies has been a hard constraint on the Government's efforts. In this light, further prioritization of poverty reduction strategies becomes very important. 


\section{Assessment of macroeconomic developments}

Tajikistan has shown strong real economic growth in the last five years. Macroeconomic stability on broad terms has been attained despite uneven inflationary performance and vulnerability to external shocks.

More recently, the overdependence of economic performance to production of cotton and aluminum has moderated as the economy started to diversify. The impact of structural reforms resulted in increases of non-cotton agricultural goods and non-aluminum manufacturing. The share of the services sector in the GDP has been steadily growing. Some of the more recent economic growth came from increased domestic demand resulting from workers' remittances from abroad. However, the growth of the importance of migrant worker remittances may contribute to economic vulnerability because in the longer term it is difficult to sustain. Also, many migrant workers earning their livelihood in foreign countries mean that the domestic economy is not creating enough job opportunities for the population.

Table 2. General Macroeconomic Indicators, 1999-2003

\begin{tabular}{lrrrrr} 
& \multicolumn{5}{c}{ Actual } \\
\cline { 2 - 6 } & $\mathbf{1 9 9 9}$ & $\mathbf{2 0 0 0}$ & $\mathbf{2 0 0 1}$ & $\mathbf{2 0 0 2}$ & $\mathbf{2 0 0 3}$ \\
\hline GDP (mill Sm.) Real & 1,345 & 1,807 & 2,512 & 3,345 & 4,758 \\
GDP (\% change) & 3.7 & 8.3 & 10.3 & 9.1 & 10.2 \\
Inflation (end of period) & 30.1 & 60.6 & 12.5 & 14.5 & 13.7
\end{tabular}

GDP distribution (\%)

\begin{tabular}{lrrrrr}
\hline Agriculture & 25.4 & 27.0 & 26.7 & 22.0 & n.a. \\
Industry Trade & 21.7 & 23.9 & 22.6 & 18.7 & n.a. \\
Construction & 19.7 & 18.3 & 19.3 & 19.4 & n.a. \\
Other & 5.4 & 3.4 & 4.1 & 2.6 & n.a. \\
& 27.8 & 27.5 & 27.4 & 37.3 & n.a.
\end{tabular}

\section{Foreign trade (USD mill)}

\begin{tabular}{lcrrrr}
\hline Exports & 689 & 784 & 652 & 734 & 798 \\
Imports & 663 & 675 & 682 & 721 & 881 \\
Net exports & 26 & 109 & -30 & 13 & -83 \\
External Debt $(\%$ GDP) & 118 & 128 & 99 & 82 & 73 \\
Current Account $(\%$ GDP) & -3.4 & -6.5 & -7.1 & -2.7 & $-1.3^{*}$ \\
& & & & & \\
\hline
\end{tabular}

Source: $M O F$, MOET, SSC, NBT. (*)Preliminary data.

Inflation rates, since 2000, have moderated, but have remained uneven and relatively high with respect to Government's targeted levels. In the past, external shocks have played intermittent and large role in higher inflation rates. However, the main reason in persistently moderate inflation rates has been the weakness in monetary policy implementation. The National Bank of Tajikistan does not have adequate monetary instruments and expertise to timely manage the monetary aggregates. The lack of independence of NBT activities from Government policies has, also on occasion, contributed to uneven monetary policy implementation. 
Table 3. Revenues and Expenditures by Functional Type, 1999-2003 (\%GDP)

\begin{tabular}{lrrrrr} 
& 1999 & 2000 & 2001 & 2002 & 2003 \\
\hline Revenue & 14.5 & 13.8 & 15.1 & 16.0 & 17.2 \\
Expenditure 1/ & 17.6 & 14.4 & 15.2 & 16.1 & 16.2 \\
$\quad$ Education & 2.1 & 2.3 & 2.4 & 2.6 & 2.4 \\
Health & 1.0 & 0.9 & 1.0 & 0.9 & 0.9 \\
Social Protection & 2.1 & 1.8 & 1.9 & 2.1 & 2.3 \\
Mgmt, defense, law and order & 5.5 & 5.2 & 4.6 & 4.9 & 4.7 \\
Economic sectors & 4.4 & 2.9 & 3.0 & 2.7 & 3.0 \\
Other & 2.5 & 1.3 & 2.3 & 2.9 & 2.9 \\
Deficit 1/ & -3.1 & -0.6 & -0.1 & -0.1 & 1.0 \\
& & & & &
\end{tabular}

Source: $M O F$

1/ Excludes externally financed public investments program.

Fiscal policy performance has improved over the medium-term. The new tax code, which came into effect in 1999, simplified the taxation system. Since then, the tax administration and the customs administrations have been consolidated and strengthened. In response, mainly to these developments, the tax revenues have been gradually increasing. The budget expenditures have been tightly managed. As a result, the budget deficits have been declining in the recent years. In 2003, there was a budget surplus. The Government, in compliance with the policy of targeting social sectors, has increased the share of the expenditures in social sectors. The raising of tariffs for electricity and gas to cost recovery levels and increasing collection rates have reduced the quasifiscal deficits. However, the quasi-fiscal deficits continue to be a relatively high.

Table 4. Expenditures by Economic Type, 2002-2003 (\% GDP).

\begin{tabular}{llrr} 
& & $\mathbf{2 0 0 2}$ & $\mathbf{2 0 0 3}$ \\
\hline I & Total expenditure \& net lending (II+V) & 16.1 & 16.2 \\
II & Total expenditure (III+IV) & 16.0 & \\
III $\quad$ Current expenditure & 12.9 & 16.1 \\
& Expenditure on goods \& services & 7.8 & 8.3 \\
$\quad$ Wages \& salaries & 3.4 & 2.8 \\
$\quad$ Other purchases of goods \& services & 4.4 & 5.6 \\
Interest payments & 1.5 & 1.2 \\
$\quad$ Domestic & 0.5 & 0.5 \\
$\quad$ Foreign & 0.9 & 0.7 \\
$\quad$ Transfers to households & 2.7 & 2.7 \\
$\quad$ Subsidies and other transfers & 0.5 & 0.4 \\
Iv $\quad$ Capital expenditure & 3.2 & 3.5 \\
& Centralized investments & 2.1 & 2.2 \\
Other & 1.1 & 1.4 \\
V Total lending minus repayments & 0.0 & 0.0
\end{tabular}

Source: MOF (Expenditure excludes externally financed public investments program.) 
Disciplined fiscal policy, with low deficits, has alleviated Tajikistan's external debt sustainability. The Government has limited its external borrowing and negotiated restructuring of its debts. The Government has limited the foreign-financed component of PIP to 3 percent of GDP. As a result of debt restructuring, as well as strong economic performance, the total external debt as a share of GDP has declined to 73 percent at the end of 2003 from 82 percent of GDP at the end of 2002. External debt management has also been improved.

The national currency, Sm., has depreciated significantly since 2000. However, more recently, the depreciation rate has dramatically slowed due mainly to the performance of the economy. In 2003, there has been a slight appreciation against the US dollar even though Sm. has depreciated against the Russian Ruble, which is an important trading partner. Recently, external current account deficit improved from increased workers remittances. However, the foreign currency reserves have remained at the level of about two months' worth of imports, because of increased imports demand. Tajikistan's exchange rate policies are relatively liberated. The National Bank intervention in the exchange rate valuation is limited to strengthening the national currency rather than defending it against free-floating exchange rate depreciations.

In 2003, the real GDP grew by 10.2 percent. Inflation rate, at 13.7 percent, was above the initial policy target of 7 percent. One of the reasons in the higher inflation rate was the effect of the one-time amnesty on declaring cash holdings without source documentation. On the fiscal side, main fiscal parameters improved and the budget showed a surplus. The Government fiscal policies have been linked to the need to target the surplus towards more targeted spending in social sectors and also in servicing the external debt.

Looking ahead in the medium-term, during 2004-2006, the real economic growth rate is expected to settle to more sustainable levels as the structural economic reforms are broadened. The production of cotton and aluminum will remain important but the economic growth will mainly come from non-cotton agriculture, non-aluminum manufacturing, and growing services sector. Migrant worker remittances, increased regional trade and reforms in agricultural sector will drive the domestic demand. During this period, inflation rates are expected to decrease. Lower inflation rates are expected as restructuring of the NBT is completed and its capacity in monetary policy implementation is increased. As well, the effects of the amnesty program for repatriating cash holdings will have dissipated.

In the medium term, the budget expenditures are expected to rise together with the increased budget revenues. The revenue increases during 2004-2006 are expected from improved economic activities and also from the implementation of the new tax code, which will simplify taxation, enhance tax administration and increase compliance further. In 2004, the budget has allocated 7.4 percent of GDP towards social sectors. The expenditures in the education, health and social protection sectors will be gradually increased during 2004-2006. In the immediate future, increasing external debt servicing will contribute to the difficulties in the expenditure policy. During the medium term period, slight but declining budget deficits are expected. 
Table 5. Medium-Term Budget Framework, 2004-06

\begin{tabular}{lrrr}
\hline & \multicolumn{3}{c}{ Forecasts } \\
\cline { 2 - 4 } & 2004 & 2005 & 2006 \\
\hline GDP (in millions of somoni) & 5,750 & 6,461 & 7,122 \\
Real GDP growth (in percent) & 8.5 & 7.5 & 6.0 \\
Inflation (end-of-period, in percent) & 7.0 & 5.0 & 5.0 \\
& & & \\
General Government Finances (in percent of GDP) & & & \\
& & & \\
\hline Total Revenue & 17.7 & 17.9 & 18.2 \\
Employers' contributions to the SPF & 1.8 & 1.8 & 1.8 \\
VAT & 5.3 & 5.0 & 5.0 \\
Excise tax & 0.8 & 0.9 & 0.9 \\
Sales tax (cotton, aluminum) & 1.9 & 1.7 & 1.5 \\
Income and profit taxes & 1.4 & 1.4 & 1.5 \\
Other tax & 4.1 & 4.8 & 5.0 \\
Non-Tax & 2.4 & 2.4 & 2.5 \\
Total Expenditures minus net lending 1/ & 18.1 & 18.4 & 18.2 \\
Education & 3.1 & 3.3 & 3.4 \\
Health & 1.4 & 1.6 & 1.6 \\
Social Protection & 2.0 & 2.2 & 2.2 \\
Management, defence and law \& order & 4.4 & 4.4 & 4.3 \\
Economic sectors & 2.1 & 2.1 & 2.0 \\
Other & 5.1 & 4.8 & 4.7 \\
Deficit 1/ & -0.4 & -0.5 & 0.0 \\
Externally financed PIP & 3.0 & 3.0 & 3.0 \\
External debt 2/ & 61.0 & 59.4 & 57.7 \\
\hline
\end{tabular}

Source: Ministry of Finance.

1/ Excludes the externally-financed Public Investment Program (PIP).

2/ Assuming full disbursement of PIP projections.

During the next stage of PRSP realization, the GRT plans to facilitate the structural reforms of privatization and in banking and social sectors. In particular, we intend to strengthen restructuring of agricultural enterprises and lands, privatization of the large and medium enterprises, to establish legal and procedural business environment for encouraging entrepreneurial initiatives, to simplify tax administration and reduce tax burden, to rehabilitate transport and communication infrastructures, and to establish banking system and credit institutions to facilitate investments. In the public sector, we will reform the social sector service delivery and increase our investments in the human capital of Tajikistan. In education sector, relevant costs, including reformipg of financing of education with granting the more independence to schools, will be reflected. In health sector, primary health care policies will be implemented. Intergovernmental reforms to distinguish the responsibility and authority between local and central government bodies will guide some of the changes in public resources management. The GRT will promote activities to lower rates of inflation, will improve private sector growth policy, and will continue disciplined fiscal policy while sustaining high social sphere expenditures and improving civil servant wages and services. Government believes that these economic policies will consolidate macroeconomic stability, and sustain real economic growth and contribute to real improvements in the standards of living of the population. 


\section{Poverty analysis update}

In 2003, the GRT drafted and published the Report on Achievement of Millennium Development Goals in Tajikistan with the support of UNDP. The MDG are, on the whole, in agreement with the priorities and tasks of the PRSP. Table 6 assesses, broadly, necessary policies and chances of achieving development goals and PRSP objectives by 2015 .

Table 6. UN MDG and GRT PRSP targets 2002-2015.

\begin{tabular}{|c|c|c|}
\hline & Goal and tasks & Assessment and necessary conditions \\
\hline 1. & $\begin{array}{l}\text { Liquidation of extreme poverty and } \\
\text { hunger } \\
\text { 1. Halve the share of poor } \\
\text { population by } 2015 \text {; } \\
\text { 2. Halve the number of the } \\
\text { population suffering from hunger } \\
\text { by } 2015 \text {. }\end{array}$ & $\begin{array}{l}\text { With stable economic growth rates of } 5 \% \text { as well } \\
\text { as continuation of progressive and effective } \\
\text { structural economic reforms, the poverty level } \\
\text { can be halved by } 2015 \text {. }\end{array}$ \\
\hline 2. & $\begin{array}{l}\text { Provision of elementary education. } \\
\text { By 2015, children will be provided } \\
\text { opportunities of full elementary } \\
\text { education. }\end{array}$ & $\begin{array}{l}\text { Tajikistan can provide elementary education to all } \\
\text { boys and girls by } 2015 \text { provided that: } \\
\text { - The Government, civil society and private } \\
\text { sector of Tajikistan, and the international } \\
\text { community take proactive joint actions. }\end{array}$ \\
\hline 3. & $\begin{array}{l}\begin{array}{l}\text { Extension of rights and } \\
\text { opportunities for women. }\end{array} \\
\begin{array}{l}\text { Liquidate gender disparity in } \\
\text { elementary education and } \\
\text { secondary education }\end{array}\end{array}$ & $\begin{array}{l}\text { The level of gender disparity in elementary } \\
\text { education remains high. The economic difficulties } \\
\text { and social changes of the transition period } \\
\text { lowered the coverage ratio of girls in the basic } \\
\text { education levels (especially girls from poor } \\
\text { families). This gender gap may further increase } \\
\text { and it will be difficult for the country to achieve } \\
\text { gender equality by } 2015 \text {. }\end{array}$ \\
\hline 4. & $\begin{array}{l}\text { Reduction of child mortality. } \\
\text { Reduce mortality among the } \\
\text { children under } 5 \text { years by } 2 / 3 \text {. }\end{array}$ & $\begin{array}{l}\text { The situation on child and maternal mortality } \\
\text { remains complicated and has been difficult to } \\
\text { track. Official statistical data and results of } \\
\text { independent surveys are inconsistent regarding } \\
\text { the slowdown of infant and maternal mortality }\end{array}$ \\
\hline 5. & $\begin{array}{l}\text { Improvement of maternity } \\
\text { protection. } \\
\text { Reduce maternal mortality } \\
\text { coefficient by } 3 / 4 \text {. }\end{array}$ & $\begin{array}{l}\text { during the period since } 1990 \text {. } \\
\text { unlikely to reduce child mortality by } 2 / 3 \text { and the } \\
\text { maternal mortality coefficient by } 3 / 4 \text {. }\end{array}$ \\
\hline 6. & $\begin{array}{l}\text { HIV/AIDS control and control of } \\
\text { malaria and other diseases. } \\
\text { 1.Contain HW/AIDS and initiate. } \\
\text { reduction of incidence rate; }\end{array}$ & $\begin{array}{l}\text { - Actions in accordance with the Strategic Plan } \\
\text { on Prevention of Spread of HIV/AIDS assume } \\
\text { that it is possible to stabilize the situation by } \\
2015 \text {. }\end{array}$ \\
\hline
\end{tabular}




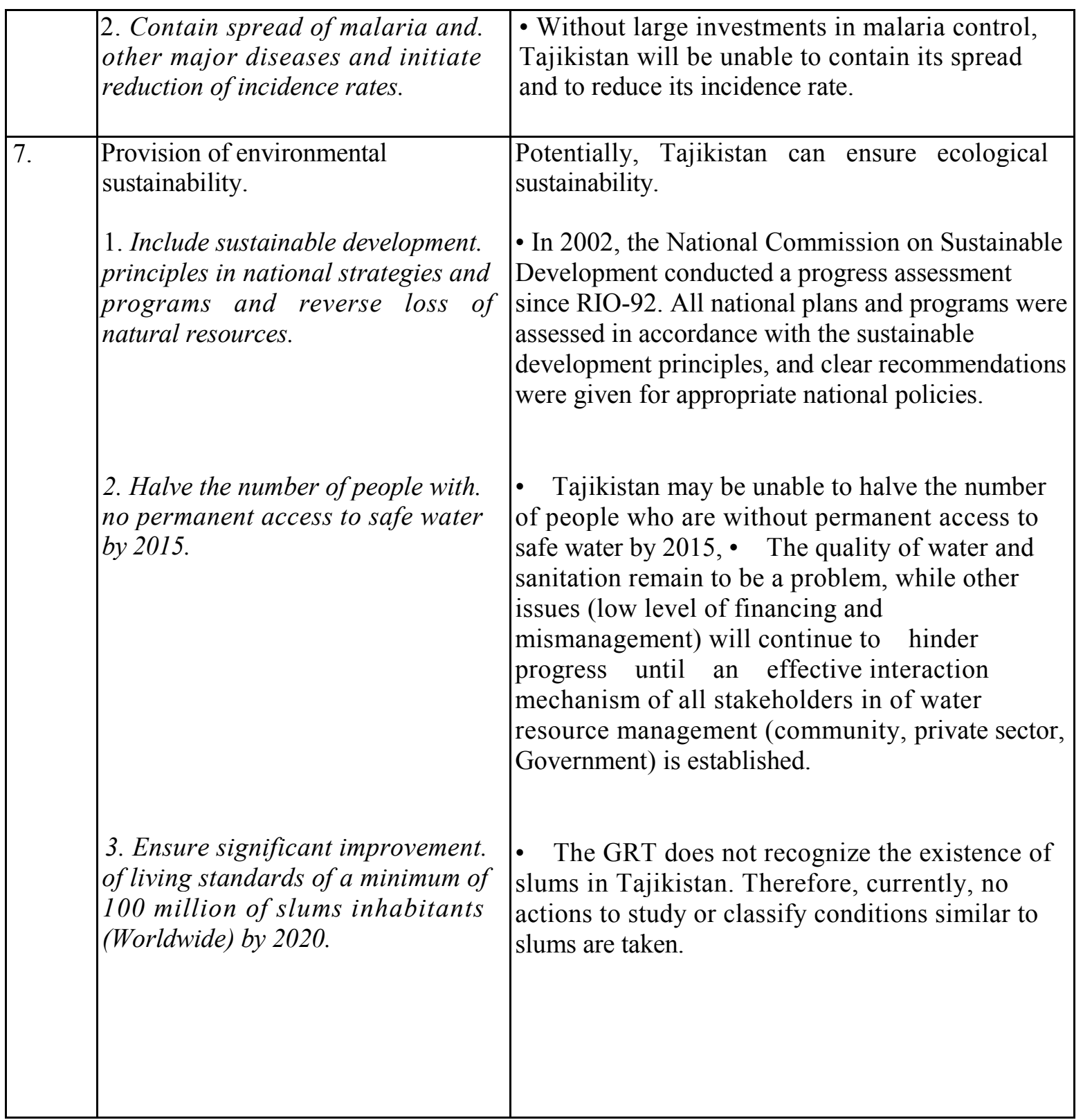

Source: Report on Achievement of Millennium Development Goals in Tajikistan, GRJ: 2003.

Number of household surveys and other studies were used for the current report. We present details of results from selected surveys in Attachment 3. The data covers a period longer than our PRSP reporting period. Both the GRT institutions and the donor organizations collated information to understand the poverty status in Tajikistan. Based on the current information, the first progress report will show more the depiction of poverty than a quantified change through time, which would have given us a fuller understanding of poverty.

In the process of preparing the Progress Report, it became clear that to measure the effectiveness of poverty reduction strategies requires upgrading of existing statistical systems to provide reliable, consistent, and timely data. With the current level of information on the key issues in poverty identification, and with the weak data collection system it has been difficult to produce a highly quantitative evaluation of PRS progress. In the process of drafting the Report, significant gaps in data on poverty issues and organizational lapses in utilizing the access to information were 
discovered. Different methodologies of surveys for poverty assessment created problems in planning and implementation of policy measures aimed at poverty reduction. However, we have benefited during the preparation of this Report in identifying current problems and we are drafting specific measures to overcome the shortcomings. The GRT is addressing these issues with the help of the donors. A Trust Fund Grant technical assistance agreement was signed to improve statistical capacity of SSC. The PRSP Monitoring Department is receiving technical assistance in designing methodology of monitoring and evaluation of poverty data.

The GRT has chosen a number of poverty indicators to be able to measure progress in poverty reduction. Some indicators were established as part of the UN MDG. Below we summarize the status of these indicators as of 2003. PRSP Monitoring Department is reviewing other indicators in order to target development goals for Tajikistan.

\subsection{Basic education coverage}

Basic education (compulsory grades 1-9) coverage has been declining since the early 1990s. In 1989, the coverage stood at $94.3 \%$. In 2000, it had fallen to $88.4 \%$. Recent data shows, that coverage in basic education rose to $94.4 \%$ in 2002 from $93.2 \%$ in 2001 . The situation has been similar with elementary education (grades 1-4). The data on elementary education shows that coverage increased to $79.1 \%$ in 2002 from $77.7 \%$ in 2001 . We do not have gender specific data, for which we will take measures to rectify.

\subsection{Infant mortality}

There is large variance in infant mortality rates in the data, which come from various sources. Main reason for the conflict in data is the definition of live births. The definition of livebirth used by $\mathrm{MOH}$ underestimates infant mortality rates relative to the WHO standards. According to the $\mathrm{MOH}$, infant mortality rates per 1000 live-births were as follows: in 2002 17.2, in 200127.9 , and in 2000 15.5. Latest information for 2003 shows the rate to be 16.7, which does not include information from deliveries at home. UNDP reports that the unattended home deliveries are $40.7 \%$ in the country (up to $80 \%$ in some regions).

On the other hand, a UNICEF MICS study indicated infant mortality rate of 89 in 2000. In the same study the mortality rate for children under 5 was 126 . Definition of live-birth under the WHO standards was introduced to our data collection practice at the end of 2003.

\subsection{Maternal mortality}

Official maternal mortality indicator has declined to 50.6 per 100,000 live births in 2002 from 97.7 in 1995. The levels of maternal mortality in some regions range from 157.1 to 1075.3, which supports the fact that poverty has strong regional character in Tajikistan. In 2002, maternal deaths were from hemorrhage (30.4\%), pre-eclampsia (30.4\%), extra-genital diseases $(13.9 \%)$, and complications resulting from infections $(10.1 \%)$. Anemia is prevalent among registered pregnant women (50.3\%). Overall registered abortions have been declining except among adolescents, for whom it has become a recent cause of maternal mortality. 


\subsection{Access to health services}

Preliminary results of the WB Assessment of the Living Standards in Tajikistan in 2003 (fLSS) prove that access to health services deteriorated since 1999. The ratio of physicians in population was 20.3 per 10,000 persons in 2002 . This rate is 47.0 for paramedical personnel.

There is no detailed information on the number of population having access to basic medicines. According to the WHO study, there is no guaranteed supply of standard basic medicines to the socially vulnerable population. Public pharmacies stock only $25.7 \%$ of basic medicine supply inventories. This rate is $66.4 \%$ at private pharmacies and is $37.3 \%$ at district hospitals.

\subsection{Access to safe water}

In general, $57 \%$ of the population has access to reasonably safe water. UNICEF studies prove that only $40 \%$ of the Tajikistan's population uses freshly piped water at home or outdoors. Another $8 \%$ uses wells, $6 \%$ uses bore-holes, and $33 \%$ get water from unreliable sources. According to statistics, $51.2 \%$ of the population uses the infrastructure of the water supply system and $48.8 \%$ uses water from other sources with questionable sanitary-epidemiological condition. Analysis of water quality conducted by sanitary-epidemiological stations during the last two years in Khatlon and Sugd regions showed widespread chemical and bacteriological contamination.

Table 7. Water contamination (2002, 2003)

\begin{tabular}{|l|c|c|}
\hline & $\begin{array}{c}\text { Khatlon Region } \\
\%\end{array}$ & $\begin{array}{c}\text { Sugd Region } \\
\%\end{array}$ \\
\hline Bacteriological & 54.7 & 27.5 \\
\hline Chemical & 47.3 & 20.6 \\
\hline
\end{tabular}

Source: Epidemiological stations.

According to the NNWSS 2003, bacteriological analysis of 380 water samples, nationwide, shows that $41.1 \%$ of the water was of unacceptable and grossly polluted categories!' The majority of the contaminated water samples were collected directly from the water source while the majority of samples for acceptable quality water were collected from piped taps or hand pumps.

\subsection{Employment}

Officially, total unemployment rate according to ILO definition is $11.3 \%$. Urban unemployment rate is higher $(13.2 \%)$ than rural unemployment rates $(10.9 \%){ }^{2}$ According to the official statistics, average labor force in 2002 was 3,477,000 people. In 2002, labor participation rate in the economy was $53.4 \%$, which fell from $57.3 \%$ in 1999 . Part of the decline is the result of the change in the broadening of age brackets in the definition of labor force. The new age brackets for labor force are, for men 15-62 (earlier 16-59) and for women 15-57 (earlier 16-54).

\footnotetext{
${ }^{1}$ Mean count of thermo tolerant $\mathrm{E}$ coli greater than 11 at $44^{\circ} \mathrm{C}$ in $100 \mathrm{mI}$. This is the main indicator of risk of contracting water borne and water related diseases.

2 According to the poverty monitoring assessment conducted with the support of the Asian Development Bank in 2002.
} 
In recent years, migrant worker component of the labor force has gained significance. The prolonged lack of job opportunities in the domestic economy is forcing growing number of workers to other countries. According to the MLSP, the number of labor migrants abroad was around 210.000 people. Of these, more than $85 \%$ work in the Russian Federation. The majority are male (91\%) and are between the ages of $18-29$ years $(62 \%)$.

\subsection{Private sector share in the GDP}

It has not been possible to identify accurately the share of the private sector in the GDP. A large share of the private sector is part of the informal economy. The SSC has not officially estimated this. According to one estimate, in 2002, the share of private sector activities in the economy was $32 \%{ }^{3}$ According to the $\mathrm{ADB}$, the share of the private sector in national output was $50 \%$. Currently, private sector activities are dominated by small businesses enterprises with legal entity status, small businesses licensed by 'patents' and private dehkan farms.

\subsection{Access to telecommunications}

In 2003, nationally, access to telephones was 3.8 land lines for 100 persons. The urban population uses $85 \%$ of all telephones lines. The access to land line telephones in rural areas is still 0.8 per 100 persons. This statistic roughly translates that about one percent of rural population has access to basic telecommunication infrastructure. The telecommunications sector is in the process of upgrading with improvements in mobile phone coverage, upgrading of telephone lines and switches, and broader Intemet services. $\mathrm{m} 2003$, access to mobile phones rose to 0.80 per 100 people from 0.14 in 2002 . The use of mobile phones is also essentially an urban area phenomenon.

\section{4. $\quad$ PRSP policy implementation: 2002-2003 4.1}

\subsection{Administration and governance}

\subsubsection{Governance organs}

Effective governance is one of the main elements of the PRSP along with accelerated economic growth and targeted support to the disadvantaged population. To improve governance management, many ministries, agencies, and the Office of the President have undergone restructuring processes in the recent years. The State Financial Control Committee was created in 2001 to increase effectiveness and transparency in the use of public funds and property. Increased transparency in the operations of government bodies is provided by periodic publications, in the media, of new legislations, of essential policy decisions, including state budget execution reports and results of audits.

In 2002, to strengthen the state service system, the Civil Service Department was created. Functional reviews were conducted by the Public Administration Reform component of the IBTA-II Project. The recommendations from the functional review have not been fully acted on. Over the period, the public sector employment was reduced by almost $5 \%$ through job attrition. Also, the legal base for a Register of state positions and qualification requirements was adopted (December 2002). For

CARANA Corporation Study. 
training of qualified civil servants, Professional Development Institute was established in October 2002. The under-funded Institute was not active in 2003.

The SFCC is directed by law to audit annual government final accounts and to report the results to the Parliament and the President. Other internal audit reports are available to the public through the media. During the reporting period, concrete measures to increase the auditing capacity of the SFCC and to create a mechanism to review the SFCC audits did not occur. The GRT and SFCC are working on means to fulfill the potential of SFCC towards government accountability and transparency by resolving the issues of auditing capacity and the appearance of dependence of SFCC on the executive branch.

Another measure in increased accountability, which is considered, is decentralized provision of services. This involves community participation and strengthening local government accountability and financial management. In farm privatization process, the Government has tried to divest control from local authorities with respect to farmers' production decisions. Because this measure requires an informed population to have effectiveness, the GRT, is educating the stakeholders about their rights and available legal recourses.

State budget does not financially support some public sector management agencies. These agencies financially depend on the enterprises, which they are supposed to regulate. This relationship compromises independence of the agencies. Other departments after restructuring are still directed to implement centralized economic decisions. This applies to executive governance bodies, financial managers as well as legislative and judicial systems.

The expected impact from restructuring of ministries and agencies has not fully taken root. Transparency and accountability are not embraced priorities yet. The most conspicuous reason for the delay in extensive gains in governance management organs seem that the GRT has not had a single coherent practical approach. The GRT has received draft recommendations from the WB regarding policies on state procurement processes, auditing standards and procedures, MOF functions regarding expansion of treasury functions, independence of the SFCC, and greater involvement of stakeholders in the public expenditure management. The GRT considers follow-up actions on the recommendations of public sector management issues as well as on functional reviews with renewed emphasis in the next PRSP implementation cycle.

\subsubsection{State budget management}

Despite continuing structural reforms in the budget management, budget allocations continue to reflect a planned economy system. Budget management process has not had the occasion to integrate PRSP priorities and its financial requirements into the state budget. In 2003, even though $43 \%$ of the state budget expenditures were towards social sector needs, this does not imply that the PRSP priorities were addressed. The adoption of PRSP as government economic policy has not filtered into all the government organs. The PRSP priorities have not been explicitly communicated to the MOF, other ministries, and local authorities in a manner to link the budget allocations and the PRSP.

The GRT is working on measures to improve the effectiveness of the budgetary system. The creation of a Budget Commission has been under consideration. The Budget Commission is expected to guide the budget process strategically and to target budget expenditures on the priorities of the PRSP. The 
Commission is also expected to improve the communication among the government organs and the population at large through the Parliament and CSOs. The preparation of a full medium-term budget framework by the MOF would start the budget management process to incrementally integrate PRSP priorities. In the meantime, the automated Treasury fimctions will be extended to local units to improve their budget management. The MOF will also establish a cash management unit and participate in the treasury securities market to further institutionalize the treasury fmctions.

The MOF, in 2002 and 2003, developed draft MTBF, respectively, for the periods of 2003-2005 and 2004-2006. The ministries and agencies now have the basic capacity to prepare the annual budgets under 'programs.' Therefore; the MOF has the ability to prepare and present the annual budget for 2005 to the GRT and the Parliament as a part of a full MTBF for the 2005-2007 budget years. The GRT believes that the preparation and presentation of the budget under the format of budget programs (reflecting PRSP targets) and the associated Key Budget Organizations (KBO) will provide concrete improvements in transparency and accountability in budget preparation and execution. The MOF will revise the budget classification to facilitate the new budget preparation and execution. The GRT, Budget Commission, Parliament and stakeholders will be able to measure more tangibly the purposes and the targeting of budget expenditures with the new budgeting process.

At the same time, the management of the state budget must consolidate the expenditures on capital investments within the context of PRSP prioritizations. Currently, the state budget coverage includes centralized capital investments and externally financed PIP. However, unless the state budget is prepared in a singularly integrated structure, the budget allocations (current and capital) can not separately target the same set of poverty reduction policies in the most effective manner. The GRT, to improve targeting of investments in the public sector has created a PIP Unit in MOET. The MOET is receiving donor technical assistance to improve upon the PIP preparation and management. The MOF, MOET and the ACU are in the process of delineating the tasks in the management of PIP financing and other donor contributions. The MOF is receiving donor technical assistance in external debt management.

\subsubsection{Public Investments Program 2004-2006}

To address some of the medium term PRSP objectives the GRT prepared PIP 2004-2006. The PIP 2004-2006 is a continuation of earlier public investment programs. It tries to strengthen the current PRSP initiatives and for the first time, the PIP 2004-2006 recognizes the debt burden of the public sector. The PIP limits the annual external borrowing to $3 \%$ of the GDP for 2004. For the outer years, the GRT plans to revise annual external borrowing levels in accordance with the changing economic conditions. The borrowing constraint is based on the medium-term macroeconomic framework. The debt service of the state budget as a percentage of the annual revenues is high and will increase in the next few years.

For priority financing projects in 2004, the planned amount is USD83.8 million of which USD 63.8 million are in loans. Of the total USD 63.8 million in 2004, about USD 17 million is not direct borrowing of the GRT. ${ }^{4}$ Therefore, for 2004, the external borrowing is under 3\% of GDP. The PIP 20042006 , to be financing by loans, consists of 41 projects for a total sum of USD 343.1 million. Twenty

\footnotetext{
${ }^{4}$ The planned borrowings on two projects are re-classified that they were not public sector borrowings (energy sector IDB-ADB loans for USD 7 mill. and communications sector EBRD loan for USD 10 mill.).
} 
projects for USD 246.7 .million are ongoing and 21 projects for USD 96.4 million are for new projects. In the coming years, the PIP projects may need to be more highly prioritized to better reflect the PRSP objectives.

The total amount of investments in the social sectors of public health, education, social protection and employment, expansion of a private sector and multi-sectors constitute USD 71.8 million or $21 \%$ of the total amount. Projects in agricultural sector, irrigation, and water supply make up USD 93.1 million or $27 \%$. Projects in these sectors are aimed at reforming the agricultural sector, creation of private dehkan farms, rehabilitation of a rural infrastructure and improvement of water supply.

Table 8. PIP 2004-2006 bv sector (USD Mill)

\begin{tabular}{|c|c|c|c|c|c|c|}
\hline \multirow[t]{2}{*}{ Sector } & \multicolumn{2}{|c|}{ On-gomgSector PIP } & \multicolumn{2}{|c|}{ New PIP } & \multicolumn{2}{|c|}{$\begin{array}{l}\text { Sector AllocatIon } \\
\text { 'T0tal }\end{array}$} \\
\hline & $\begin{array}{l}\text { US\$ } \\
\text { mill }\end{array}$ & \begin{tabular}{|c|}
$\%$ in \\
total
\end{tabular} & $\begin{array}{l}\text { US\$ } \\
\text { mill }\end{array}$ & $\begin{array}{l}\% \text { in } \\
\text { total }\end{array}$ & $\begin{array}{l}\text { US\$ } \\
\text { mill }\end{array}$ & $\begin{array}{l}\% \text { in } \\
\text { total }\end{array}$ \\
\hline $\mathbf{l}$ & 2 & 3 & 4 & 5 & 6 & 7 \\
\hline Economic Management & 8.0 & 3.2 & 0.0 & 0.0 & 8.0 & 2.3 \\
\hline Agriculture & 22.5 & 9.1 & 8.0 & 8.0 & 30.5 & 8.9 \\
\hline Irrigation and Rural Water Supply & 29.2 & 11.8 & 6.2 & 6.2 & 35.4 & 10.3 \\
\hline \begin{tabular}{|l|} 
Water Supply and Sewage \\
\end{tabular} & 22.7 & 9.2 & 4.6 & 4.6 & 27.3 & 8.0 \\
\hline Energy & 62.4 & 25.3 & 31.6 & 35.0 & 93.9 & 27.4 \\
\hline Transportation & 55.0 & 22.3 & 6.6 & 6.6 & 61.6 & 18.0 \\
\hline Communications & 10.2 & 4.1 & 4.5 & 4.5 & 14.7 & 4.3 \\
\hline Education & 2.9 & 1.2 & 14.6 & 14.6 & 17.5 & 5.1 \\
\hline Health & 2.6 & 1.1 & 3.1 & 3.1 & 5.7 & 1.7 \\
\hline Social Security and Labour & 16.3 & 6.6 & 0.0 & 0.0 & 16.3 & 4.8 \\
\hline \begin{tabular}{|l|} 
Private Sector Development \\
\end{tabular} & 0.0 & 0.0 & 11.5 & 11.5 & 11.5 & 3.4 \\
\hline Multisector and Other & 15.0 & 6.1 & 5.8 & 5.8 & 20.8 & 6.1 \\
\hline TOTAL & 246.7 & 100.0 & 96.4 & 100.0 & 343.1 & 100.0 \\
\hline
\end{tabular}

Source: $M O E T$

Projects in energy sector aimed at construction and rehabilitation of infrastructure are $27.4 \%$ of PIP. The transport sector allocates $18 \%$ of PIP resources for construction and rehabilitation of roads and highways. The program of Grants and Technical Assistance consists of 128 projects for about USD 180 million. Sixty-two projects already have committed funding. Social sector projects are about USD 80 million or $45 \%$ of the total. Economic management sector has 17 projects for USD 15.2 million or $8.5 \%$ of the total. 
Results of Consultative Group Donor meetings, held in May 2003 and interim meetings in November 2003 indicated that donors are interested to see clearer process of prioritization especially by sectors. The failure of prioritization may be influencing the level of donor disbursements. The GRT is in the process of reprioritizing sector strategies.

Table 9. Grants and Technical Assistance Proe;ram, PIP 2004-2006 bv sector (USD thou.)

\begin{tabular}{|c|c|c|c|c|c|}
\hline \multirow{3}{*}{$\begin{array}{c}\text { 1apIe 9. Grants and tecnnical Assist } \\
\text { Sector }\end{array}$} & \multirow{3}{*}{$\begin{array}{c}\text { Number } \\
\text { of } \\
\text { Projects }\end{array}$} & \multicolumn{2}{|c|}{ Project Costs } & \multirow{2}{*}{\multicolumn{2}{|c|}{$\begin{array}{l}\text { Sources of } \\
\text { financing }\end{array}$}} \\
\hline & & \multirow{2}{*}{$\begin{array}{c}\text { USD } \\
(\mathrm{OOO}) \mathrm{s})\end{array}$} & \multirow{2}{*}{$\begin{array}{l}\% \text { in } \\
\text { total }\end{array}$} & & \\
\hline & & & & Gov't & External \\
\hline Economic Management & 17 & 15,228 & 8.5 & 2.8 & 97.2 \\
\hline A2riculture & 14 & 25,182 & 14.0 & 1.2 & 98.8 \\
\hline Irrigation and Rural Water Supply & 7 & 10,119 & 5.6 & 9.2 & 90.8 \\
\hline Water Supply and Sewa2e & 10 & 13,571 & 7.5 & 7.3 & 92.7 \\
\hline Energy & 6 & 4,600 & 2.5 & 0.0 & 100.0 \\
\hline Transportation & 11 & 4,280 & 2.4 & 0.7 & 99.3 \\
\hline Communications & 1 & 379 & 0.2 & 0.0 & 100.0 \\
\hline Education & 4 & 12,454 & 6.9 & 8.4 & 91.6 \\
\hline Health & 21 & 58,335 & 32.4 & 8.2 & 91.8 \\
\hline Social Security and Labour & 10 & 9,252 & 5.1 & 1.0 & 99.0 \\
\hline \begin{tabular}{|l|} 
Environment \\
\end{tabular} & 8 & 2,961 & 1.7 & 3.7 & 96.3 \\
\hline Private Sector Development & 11 & 5,570 & 3.2 & 6.5 & 93.5 \\
\hline Multisector and Other & 8 & 17,932 & 10.0 & 0.6 & 99.4 \\
\hline TOTAL & 128 & 179,862 & 100.0 & 5.1 & 94.9 \\
\hline
\end{tabular}

Source: $M O E T$

\subsection{Improvement of business environment}

The private sector development is the major PRSP strategy for economic growth and poverty reduction. The strategy is multi-faceted: privatization of enterprises and agricultural lands, establishing legal and procedural business environment for encouraging entrepreneurial initiatives, simplifying tax administration and reducing tax burden, rehabilitating transport and communication infrastructures, creating opportunities for labor-intensive and export-oriented manufacturing, and establishing banking system and credit institutions to facilitate investments. The GRT is (in the process of negotiations for accession to the WTO with the implications of liberalizing its international trade regime.

A Program for 2002-2005, to implement the provisions of the Law on Government Protection and Support of Entrepreneurship was put in place. In 2003, the state budget allocated Sm. 200 thousand for implementation of the micro-credits component of the program (each in the amount of 10 thousand Sm.) to 20 entrepreneurs. However, other activities to improve transportation, storage facilities, and access to information are dormant for lack of funds. The 
Agency in charge of the Program, estimates up to 10 mill. Sm. for seed financial support for entrepreneurs and 15 mill. Sm for establishment of favorable business infrastructure.

Table 10. Number of businesses established 2000-2003.

\begin{tabular}{|l|c|c|c|c|}
\hline & $\mathbf{2 0 0 0}$ & $\mathbf{2 0 0 1}$ & $\mathbf{2 0 0 2}$ & $\mathbf{9}$ months 2003 \\
\hline $\begin{array}{l}\text { Number businesses without } \\
\text { creation of le2al entities }\end{array}$ & 60,247 & 70,254 & 71,309 & n.a. \\
\hline $\begin{array}{l}\text { Number of small business } \\
\text { subjects }\end{array}$ & 4746 & 5280 & 6050 & 6245 \\
\hline $\begin{array}{l}\text { Number of middle-sized business } \\
\text { subjects }\end{array}$ & 122 & 129 & 142 & 224 \\
\hline
\end{tabular}

Source: PRSPMD.

In 2002, a Book of Registration of Checks was introduced to reduce unwarranted inspections and illegal interferences in the activities of business entities. Single business registration system at the Justice Ministry offices was enacted. In connection with this, the Parliament is considering amendments to eliminate the requirement of additional registrations with the MOET of foreign trade entities. Many costly obstacles prevent operations in private markets (road blocks by law-enforcement bodies hamper transportation of cargos, requirement of various permits and references, and difficulties in cotton production and sales). There is not a single coordinating authority to address these issues on practical levels.

The MSRD has drafted a new tax code in 2003. The code will simplify the taxation system and improve the tax and customs administrations. Currently, the draft code is reviewed for comments. The draft code introduces a single tax for dehkan farms. ${ }^{5}$ This provision intends to lower the cost of production and simplify tax compliance of the farmers. The draft code eliminates two local taxes (retail sales tax and municipal transport maintenance), and the road users tax (a $2 \%$ value-added tax). Instead, the current VAT rate will be increased by $2 \%$. The enterprise property tax is to be replaced by minimum tax on enterprise gross revenues. In 2003, the destination principle on VAT was more broadly applied. The MSRD is computerizing its activities and implementing functional organizational restructuring. It is expected that these reforms will encourage development of small and mid-size businesses, increase tax payments compliance, and will build, in the near future, on the already growing revenue collection rates.

The MOF and the NBT are moving towards improving operations of financial markets. Properly functioning banking and credit institutions will increase entrepreneurial activities and investments. The NBT has been adopting new rules and new monetary instruments for open market

5. The single tax on dehkan farms is on the production and delivery of agricultural products excluding any industrial processing. The farmers are exempt from all other taxes. The single tax is calculated on per unit of land area. In 2003, a pilot project on single land tax is tested in four districts. The pilot program will continue in 2004 . The program will be adopted nationwide by July 1, 2004 depending on the results based on revenue potential, tax collection rates, arrears recovery, administrative ease, and effects on economic activities. 
operations. However, the treasury bills market remains underdeveloped. The MOF has not been issuing treasury bills and developing capacity in the securities market.

During the reporting period, banking services improved. The NBT regulates more closely the commercial banks. The commercial banks monitor their portfolios more prudently. Banking sector personnel has been receiving technical training with donor assistance. Agroinvest Bank, which is heavily involved in lending to cotton sector, was restructured. Other procedural simplifications made banking services more accessible. The state duty on foreign currency transfers (30\%) was abolished. Many commercial banks started performing electronic money transfer transactions. These facilitated worker remittances from abroad and generated income for the banks. Orion Bank has opened a branch bank in Germany. Orion Bank and Amonat Bank are now affiliated with Western Union money services. Agroinvest Bank provides American Express credit card services. In 2003, it is estimated that around USD200 mill, entered Tajikistan under the new money transfer methods. At the same time, the new draft Law on Microfinance Institutions will be a positive development in the sector. However, the lack of legislation and clear contract procedures, as well as low skill levels of the bank personnel preclude full banking services to businesses and individuals.

In 2003, worker remittances from abroad resulted in lowering current account deficit and increasing domestic savings. In 2003, banks also received deposits under a one-time amnesty on cash holdings, in which declaration of sources of earnings was not required. It is estimated that about USD 175 million was legally deposited into the banking system under the amnesty program. The impact of cash transfers on increasing investments to small and medium businesses was very limited. People keep low levels of demand deposits in the banks and banks remain overly cautious in their lending.

Meetings by the President with entrepreneurs, in 2002 and 2003, as well as the results of the Consultative Group Meeting of Donors in May 2003 accelerated resolving issues related to development of private sector initiatives. The GRT adopted specific action plans to simplify mechanisms affecting private sector. Legislation, which restricted activities of the private sector, was revised. Arrangements were made between ministries and departments to simplify standardization, certification and other procedures. The Administrative Code was brought into compliance with market conditions with regard to elimination of double subordination principles. Sanctions for accountability of budget executors and against corruption were strengthened. The results of these actions will be analyzed in January and February on the economic performance results of 2003.

In the agricultural sector, interventions by the local authorities in the production decisions stifle cropping diversity and productivity in the privatized lands. In September 2002, a GRT order prohibited local authority interference in the processing and sale of cotton. In particular, the practice of cotton balances used for planning and distribution of cotton and export earnings were to be discontinued. Cotton growing farms became less constrained to choose investors, to negotiate settlements with investors, and to sign export contracts at the cotton exchange. In addition, Agroinvest Bank monopoly on issuing of export permits was discontinued. Any local bank can now process the permits.

The incomes of cotton producing farms remain chronically low. The farms also remain in debt from year to year. Most of the farmers are restricted from using their lands as collateral. Nor 
are they able to register their movable assets against whose value they should be able to borrow. The market for cotton investors is uncompetitive. Law of Microfinance, on which the Parliament is currently deliberating, will address some of these issues. In the meantime, very small number of credit institutions, which also facilitate acquiring intermediate inputs, ensures that input prices are high and future cotton prices are collusively determined. Cotton growing farms are not able to participate in the cotton sale processes. The ginneries, working as local monopolies, assess quality and quantity of cotton fiber. Transportation of goods is also very costly for the growers. Poor transportation networks between the agricultural producers and the consumer markets and other scant auxiliary market services continue to hamper economic activities in the sector. According to MO A, about 10 organizations provide services on cotton processing, storage, transportation and sale and charge up to $40 \%$ of the cotton sale prices.

Resolution of other issues in the development of private initiatives is moving forward in connection with the process of joining the WTO. The process of integration into the international trade system was not highlighted in the original PRSP. The GRT, now, considers phased-in accession to WTO an important component of economic development strategy. Since 2001, much work was conducted to improve the legislation to make it compliant with the international requirements and a fairly liberal trade regime was established in the country. Despite the efforts of the GRT to liberalize international trade, the trade regime functions less than satisfactorily. Low value-added exports of raw materials still prevail in the trade structure. At the same time, volume of import of capital investment technologies and equipment for development of new industries remains low.

Currently all efforts of the GRT are aimed at completion of preparation for the first meeting of the Working Group on joining the WTO created under the WTO Secretariat. Preparation of the first Working Group meeting includes drafting of the list of initial obligations on access to the market for services, on standard forms of lowering technical barriers to trade, on health and sanitary measures, and on implementation of the WTO Agreement on trade aspects of the intellectual property rights. The MOET and an Interdepartmental Commission are implementing coordination of actions to join the WTO. In February 2003, the External Trade Regime Memorandum was officially submitted to the WTO Secretariat for distribution among the member countries. The European Union, Australia and the USA have already submitted their questions on the trade regime of Tajikistan.

\subsubsection{Privatization}

The GRT had decided that privatization of agricultural lands (in the form of land use certificates), of enterprises in finance, manufacturing, construction, tourism, and also in communication, electricity distribution, transport services would bring faster economic growth. Defining the proper role of the state in the ownership and operations of economic sectors has been a fundamental step. 


\subsubsection{Privatization of enterprises}

During the reporting period, GRT continued in its efforts to privatize mid-size and large enterprises. Appreciable movement in the privatization of mid-size and large enterprises has not occurred. The pace of privatization and the existing business environment do not yet provide the main thrust for economic growth identified under the PRSP.

The privatization of agro-processing enterprises and creation of new small and mid-size enterprises have been proceeding very slowly. Commercial policy for agricultural products is organized by the cooperative organization "Tojikmatlubot." The "Khurokvori" Company is responsible for management of the major agro-processing industries. Agro-processing, warehousing facilities and transport and distribution systems have not acquired new technologies and innovative management practices. These organizations have not made capital investments to improve operations and profitability. The potential economic growth of the sector is stunted.

Table 11. Enterprise privatizations (as of Au2ust 2003)

\begin{tabular}{|l|c|c|}
\hline \hline & SmaII enterprIses & $\begin{array}{c}\text { Mid-size and large } \\
\text { enterpnses }\end{array}$ \\
\hline Privatized & & \\
\hline Pending & 6,925 & 576 \\
\hline Total expected & 455 & 538 \\
\hline
\end{tabular}

Source: State Property Committee, 2003.

Officially, as of August 2003, out of 23,189 enterprises, which were registered as legal entities $22.2 \%$ are in the public sector and the rest are private, collective and joint ventures (including dehkan farms). Assets of main economic sectors of industry, transport, energy, communication largely remain in the public sector $(42.8 \%)$. The strategic plan of privatization for 2002-2004 targeted the acceleration and streamlining of privatization of these objects. The CARANA Corporation conducted value assessment of the state of mid-size and large enterprises. Reviews on 440 enterprises were submitted to the GRT for consideration and a database on state properties was created. The starting point of the strategic plan was to increase transparency in privatization processes. It proposed special regimes to categories of enterprises and terms and methods of privatization in major branches of economy. New privatization technologies have been developed. Changes and additions were introduced to regulate auction and tender procedures (the collateral amount is increased). Most of the amendments did not yield any improvement on procedures. For example, the bankruptcy law is not widely applied in practice. The GRT plans to increase its capacity to deepen the implementation process of the privatization of enterprises for which the WB funds can be utilized. 


\subsubsection{Privatization of agricultural lands}

The PRSP policies for private sector development in the agricultural sector target the privatization of lands, creation of favorable environment for private fam 1 initiatives, reduction of government interference in production decisions, and effective land use.

The most important component of sector restructuring is privatization of agricultural lands. Technically, the land privatization is accomplished when famlers receive 'land use certificates." Since 2002, out of 140 fam1s, 626 dehkan fam1s were established. In 2003, 1,290 thousand Sm. was allocated for further expansion of dehkan farms. The agricultural land privatization, even though quite active, has not yielded productivity gains because of various shortcomings in the process of ownership rights.

Obtaining land use certificate is an elaborate process. The State Land Management Committee issues "Land Use Certificates." The SLMC and its local chapters identify land plots for privatization in agricultural fam1 enterprises. Experimental farms, scientific research and training farms, elite seed farms, and nurseries are exempted. The Board of the farm enterprise approves, from among the farm enterprise workers, a list of qualified shareholders in the fam 1 enterprise. The list of shareholders is then submitted to the city or district land committee for allocation of land share for each farm member. The city or district chairman approves the size of the land shares. City or district land committee issues the land share certificates to every shareholder, who at the same time has to register with the land committee. The cost of the land use certificate is set at USD 6 at the official foreign exchange rate on the day of its issue.

Since 1992, to the end of reporting period, 19,565 dehkan farms have received land use certificates. However, so far, the privatization process seems to have fulfilled more the letter of the law than the intent of the law. The expected diversification in farming has not taken place. Despite all the measures, there is still unequal land distribution. This is mainly caused by lack of clear mechanism of implementation and insufficient awareness of the population of their legal rights. In instances, farmers are unaware that they have become collective dehkan farmers. ${ }^{6}$

To strengthen implementation of $1 \sim \mathrm{d}$ privatization by the SLMC and the MO A, seminars on the farm restructuring mechanism, as well as on the land use rights were conducted. Unfortunately, these seminars are not available in all the regions for lack of funds. At the Agroindustrial School, a course on famlers' rights was introduced. A department in the Agricultural University on the subject of private famling practices was set up. Improved coordination among NGOs would help in information dissemination in the land ownership restructuring process.

Another issue, which has slowed the land privatization process, has been the agricultural enterprise debts (tax arrears and other debts). The share of debt liabilities of the new farms were originally designed to be proportional to the size of the new land shares. However, the high levels of debts have discouraged diversifying the economic activities of privatized fam $1 \mathrm{~s}$. In order to reduce the burden, the GRT created, in December 2003, a Working Group to consider new financial mechanisms to write-off qualified debts.

\footnotetext{
6 "Land Reform in Tajikistan: From Capital to the Cotton Fields," Report by Action Against Hunger, October 2003.
} 


\subsubsection{Privatization and employment}

Transitional economy reforms have resulted in significant changes in the employment structure. Industrial sectors have lost considerable number of jobs while services sector added jobs. Production and employment levels in the privatized enterprises appear to be higher than during the pre-privatization period. ${ }^{7}$ Surveys conducted in Dushanbe, Khujand, and Kurgan-Tyube showed that 33 out of 188 privatized enterprises (17\%) were not functioning, while 99 out of 252 state-owned enterprises (39\%) were not functioning. Salary rates in the privatized enterprises were 60-70 Sm., compared with 25-30 Sm. in the state-owned enterprises. Thirty-six percent of surveyed privatized enterprises made investments in their own productions.

Unemployment, mostly hidden, is high. New labor market requires new institutions and labor market regulations. During the reporting period, the "Law on Employment", draft laws "On Employers Associations", and "On Labor Safety" were prepared towards these goals. The statistical methods in the new labor market are undergoing changes. The cuuent employment statistics are incomplete. In 2002, twelve new reporting forms were introduced in compliance with ILO methodology. No labor force surveys have, so far, been conducted. The PIP 2004-2006 includes technical assistance requests to improve employment statistics and migration database.

Transition from centralized planning to market economy led to the deterioration of women's relative position and they became economically more vulnerable. Women are the first employees who lose jobs. Their chances of being offered a job are less than men in the labor market. Their salaries are lower than salaries of men. Women account for $47.1 \%$ of the total economically active population. The share of women among officially registered unemployed is $54.9 \%$.

In 2002, the state budget allocated, from the Social Protection Fund, 1,680 thousand Sm., for the State Employment Program. Additional 1,074 thousand Sm. from international donors and joint projects of non-state employers were secured for the Program. Another project, the Employment Promotion Program for 2003-2005 has been in implementation since March 2003.

Table 12. State Employment Pro2ram of MLSP (2002)

\begin{tabular}{|l|c|c|}
\hline & Planned & Actual \\
\hline New jobs created & 18,900 & 46,800 \\
\hline Job vacancies filled & 18,500 & 19,800 \\
\hline Temporary public works jobs & 21,400 & 20,600 \\
\hline Disabled/unskilled labor & 1,200 & 756 \\
\hline Jobs outside the country & 5,000 & 12,000 \\
\hline TOTAL & $\mathbf{6 5 , 0 0 0}$ & $\mathbf{9 9 , 9 5 6}$ \\
\hline
\end{tabular}

Source: $M L S P$.

Overall, the MLSP Program served about 100 thousand people. The Program included activities of disseminating information on micro-credits, job fairs and employment counseling. One of the main targets of the Program was to promote employment of women. As a result, 31,184 women applied to the Program. Of these, 8,683 women received temporary public works jobs (43.4\%), 3,068 received professional training, and 8,804 started permanent jobs (18.8\%). Temporary public works jobs include construction of roads and residences, harvesting, cleaning of

${ }^{7}$ Survey by CARANA 
streets and water sluices, and municipal beautification projects. During the reporting period, a Women's Labor Exchange at Khatlon Employment Center helped to locate 351 new permanent jobs. Another 80 working women switched to new jobs. Two additional Women's Labor Exchanges are to be created in other regions. New business centers in the employment centers created 300 new jobs in 2002 and 10,800 temporary jobs in 2003. However, a few employmnent and business centers can not implement enough support for a flexible labor market through employee training and retraining and consulting and assisting in searching new jobs.

The PRSP considers important the understanding of migratory demographic processes. The GRT, as part of its labor policies, has been negotiating with foreign countries to secure legal and fair treatment of Tajik migrant workers. In 2002, new procedures for regulating labor migrants working overseas were introduced. Tajik nationals who seek jobs are now required to have labor contracts with foreign employers prior to leaving Tajikistan. This requirement will be an added burden for job seekers and difficult to enforce. The agencies and organizations, which provide emplo 1 1nent for Tajik workers abroad, are subject to licensing from MLSP. In 2002, these companies served only 12,182 people. The Shark Research Center and ILO documented that many migrant workers work outside of their own professions and without contracts. During 2002-2003, $22.2 \%$ of migrants had permanent jobs. ${ }^{8}$ The majority of the migrants worked in lower skilled jobs: construction (21\%), trade (18\%), and agriculture (17\%). About $10 \%$ were employed in jobs, which required technical skills.

\subsection{Social sector policies}

The PRSP policies in social sectors are focusing on measures to stem the deterioration of main indicators in the health, education, and social protection sectors. Many policies require major redirecting of basic ideas of public service provision. In education, increasing the coverage of basic education and especially to the very poor and to female population has become an overriding cause. In health sector, the service provision is targeting Primary Health Care and preventative medicine as the most effective means to assist the larger and more vulnerable portion of the population, i.e. the poor, the rural areas, the children and women. To deliver PHC, training of medical personnel and disseminating public health information are priorities. Initiatives are taken to provide health services on per capita basis and to design a health care financing system. In social protection sector, the GRT is using cash compensation pa 1 nents to the very poor and increasing pensions to protect the vulnerable groups. The state budget also provides financial support to populations, which were forced to relocate their settlements for various reasons. During the reporting period, many structures of educational, health care, and social protection institutions were rehabilitated.

\subsubsection{Health}

The health sector expenditures, in the recent years, from the state budget have been less than one percent of GDP (Table 2). ${ }^{9}$ In 1992, the expenditures were around $4.5 \%$ of GDP.

\footnotetext{
8 "Labor migration from Tajikistan." 10M, June 2003.

${ }^{9}$ These expenditures do not reflect spending from special funds and the contributions from the donor organizations.
} 
The GRT adopted health sector reform concept in March 2002, This plan identifies strategies to provide more equal access to public health services. The priority strategy is the development of the Primary Health Care, which is based on the family practice principles and on disease prevention. The GRT approved new organizational structure of PHC organizations in December 2002. A manual for Management of PHC was developed with assistance of the WHO. So far, the implementation of $\mathrm{PHC}$ is at pilot projects stage.

Under pilot project, (with WB financing), in Dangara and Varzob districts, six rural health centers were constructed. The ADB (under the Social Sector Rehabilitation Project), the WHO and Zdrav Plus have been pursuing similar goals in other pilot projects. The DOTS strategy is introduced for tuberculosis prevention and treatment in pilot areas. Tajik-Swiss pilot project supports health sector reforms by developing preventive medicine model and introduction of DOTS strategy. The DOTS strategy under USAID/HOPE funding is being introduced in the Dushanbe and Leninsky regions as pilot projects. The phased in DOTS strategy currently covers $13 \%$ of the population.. ${ }^{10}$

The GRT intends to extend the pilot PHC plans in a phased manner nationwide. The PHC will change rationalization of the hospital services. Restructuring of rural district hospitals to rural health centers have been initiated under the framework of rationalization plan for the pilot areas. The phasing-in process of family practice will start at some pilot institutions of the Leninsky, Bokhtar and Kulyob districts, at Dushanbe City and at regional centers Khatlon, Sugd and GomoBadakhshan Autonomous Oblasts. First clinical protocols on the most common nosologies in PHC area are already being introduced. The legal base will support implementation stages beyond pilot projects (see Attachment 2).

During the reporting period, training of family physicians and family nurses for undergraduate degrees and post-graduate degrees continued, Other training and retraining programs were developed for physicians and paramedical personnel for family practice at higher level health education institutions. Until the end of reporting period, about 300 family physicians and 200 family nurses have been trained. Similarly, a training-clinical center of family practice was set up together with the Zdrav Plus Program in Dushanbe.

In the regional family practice centers in Khatlon and Sugd, with the support of the WHO, Zdrav Plus and the ADB, more than 50 physicians and nurses were trained in order to teach family practice in secondary and higher educational establishments. Rehabilitation in 190 health institutions in the Khatlon and Sugd Regions was completed in order to create clinical family practice centers to continue with the second stage of family practice training.

Response of emergency ambulance services were improved by newly designed methods. Health officials, now, use estimating population demand based on real data of incidences. New standards for medical equipment and sanitary condition for emergency response units were defined. Currently, 28 such sanitary vehicles are active. The fonns for patient registrations at health institutions were simplified. Computerization of patient medical reports was implemented at the central district hospitals of the two pilot districts.

\footnotetext{
${ }^{10}$ The increased registrations indicate that, in 2002, the tuberculosis incidence was 82 per 100,000 people.
} 
During the reporting period, physical structures of many health institutions were rehabilitated. The list includes, Emergency Ambulance Hospital of Dushanbe, family practice dispensaries and training centers of the Central Hospital of Dangara and Varzob, Republican Center of Family Medicine, Model House of Health and Family Medicine Department of the Dushanbe Medical College, Dushanbe Family Medicine Centers (No.1) of Post-graduate Institute and (No. 2) of Tajik State Medical University. Also, emergency ambulance hospital was set up in Kulyob and repairs at maternity departments of the central district hospitals were made in RRS and Khatlon Region.

In the area of health financing system reform, Zdrav Plus Program is developing a draft Health Financing Strategy. In pilot areas, with WB support, PHC is introducing per capita financing. In health sector management area, classes were conducted under the WB Project for managers from different levels of health system $(\mathrm{MOH}$, medical educational establishments, medical and preventive treatment facilities of Dangara and Varzob areas, and regional health departments).

Information to the public on family planning and prevention of sexually transmitted diseases are available on radio and television. Reproductive health information is also disseminated through secondary and higher level schools. The UN Population Fund helped distribute contraceptives in 20 districts. A strategic plan to fight HIV/AIDS is in place. It targets portions of the population at high risk for exposure as well as protecting blood supply and prenatal transmissions. Under Zdrav Plus programs and with WHO technical assistance, information centers were created to inform the health sector personnel and the population in the proper use of medications.

The procedures in pharmaceuticals industry licensing and in importing and exporting of pharmaceuticals products were identified. The GRT is preparing protocols to secure quality control for medicines and also for providing adequate supply of tJasic medicines to the poor with assistance from the ADB. The work in improving immunization services is ongoing. Policy decisions on building a storage warehouse for vaccines, as well as the installation of Cold Chain equipment at distribution centers were made. In 2004, the state budget has allocated 90 thousand Sm. for the purchase of vaccines in accordance with a donor plan to stabilize financing of the immunization services.

Many NGOs participate in supporting the provision of health services and health sector reforms. We expect to catalog their activities in our future reports.

\subsubsection{Education}

During the reporting period, PRSP policy measures in the education sector were aimed at providing access to basic education to the poorest population and to reduce gender gap. The sector needs rehabilitation of physical infrastructure, supply of educational materials, modernizing of curricula, more teachers, retraining of teachers, higher teacher and administrator salaries, and a management system that is responsive to parents and communities.

In 2003 , the GRT spent $14.7 \%$ of the state budget on the education sector. However, because the state budget expenditures are a small percentage of GDP, the education sector 
spending, on the whole, is inadequate for sector sustainability. The salaries consume $80 \%$ of the budget allocations. Despite this, the GRT was compelled to increase the salaries of directors of schools and heads of non-school institutions by $30 \%$. Currently the average monthly salary of a teacher is $274 \mathrm{Sm}$. Still, the occasional problems of arrears in salary payments remain in some regions.

Increasing school attendance requires rehabilitated and properly equipped schools. In Tajikistan, additional financial support for the very poor to make school attendance affordable and school-provided food to entice and physically strengthen the students are necessary. According to official statistics the general nutrition content of what schoolchildren under 10 years consume is much lower than recommended levels. Large incidence of chronic malnutrition, anemia, and infectious diseases is part of the reasons for children not attending school. Humanitarian international organizations provide food in some schools to assist with this situation. Other private donations augment these programs. Total volume of this assistance is difficult to calculate because full information from the donors is not available.

The targeted scholarships plan to compensate children from the poorest families. During the reporting period, the scholarship plans for children from the very poor and remote areas were limited to quotas for girls entering higher educational establishments. Since the program's inception in 1998, 3,050 girl students entered the higher educational institutions.

Table 13. Female students admitted to higher educational institutions under Presidential quota system (1998-2003)

\begin{tabular}{|l|c|c|c|c|c|c|c|}
\hline & $\mathbf{1 9 9 8}$ & $\mathbf{1 9 9 9}$ & $\mathbf{2 0 0 0}$ & $\mathbf{2 0 0 1}$ & $\mathbf{2 0 0 2}$ & $\mathbf{2 0 0 3}$ & TOTAL \\
\hline Number of girls & $\mathbf{2 1 9 .}$ & 434 & 519 & 635 & 637 & 606 & $\mathbf{3 , 0 5 0}$ \\
& & & & & & & \\
\hline
\end{tabular}

Source: PRSPMD

Expenditures on rehabilitation and repairs from the budget on the physical infrastructure are minimal, on emergency bases and without full regard to building standards and teaching requirements. There is not a coherent assessment of the state of physical infrastructure of the educational system. No inventory of schools in need of rehabilitation or a list of required new structures exists.

According to the WB assessment, of the 1,845 surveyed schools, $26 \%$ do not have heating systems, $24 \%$ do not have running water, and 35\% do not have toilets. In Gissar district, 39 of the 40 schools were found not to have enough desks, chairs and blackboards. Many schools have broken windows. In Khatlon region, according to NGO ACTED, in 2002, 50\% of schools did not have access to water. Spending on physical rehabilitation of educational institutions comes from the state budget and the international donors. In 2003, the IDB financed rehabilitation of 7 schools, the ADB financed rehabilitation of 25 schools, and the WB financed rehabilitation of 20 schools. According to MOE, by the end of 2003, 1,154 out of 2,884 secondary schools have seen some rehabilitation.

Voluntary private assistance supplements some infrastructure development. In one instance, in Shahrinav, the community built a primary school and a two-storey gymnasium, laid electricity power lines, and fitted the school with furniture and new computers. Also, the teachers receive 10- 
$15 \mathrm{Sm}$. in addition to their salaries and poor students receive clothes. In Ganchi, dehkan farms funded the construction of a school. In Shohona village, the community built a school for 450 students, which has running water, a stadium, a cafeteria, and computer equipment. However, the potential in the communities is not usually used because the coordination skills between local governments and private donors are not well developed.

The management system in the sector is in transition. The role of school committees and Parents' and Teachers' Associations (PTA) has increased. Twenty pilot projects introduced a system of textbook leasing through the PTA to increase children's access to textbooks. Cash compensation issues are resolved through the school committees. However, these PTA institutions function differently in each school and are not reflected in the current legislations.

A MOE Resolution provides for design of new curricula for schools. The plan develops 21 curricula, 13 new textbooks and game books, and other teaching materials to be written during 2004-2007. During the 6 months of the 2003, 32 titles of textbook manuscripts were prepared. Drafting of innovative curricula in teaching and introduction of new textbooks are moving ahead. However, teaching methods are still teacher-oriented rather than student-oriented. MOE estimates that, nationwide, 86 titles of textbooks, 93,700 of desk sets, 26,206 computers are needed. Equipment and school supplies are also provided mainly by donor funds. According to the WB, in general $30 \%$ of students have textbooks and, on some subjects, only $10 \%$ of students have textbooks. There are shortages in Tajik, Russian, Uzbek, Kyrgyz, and Turkmen language textbooks. Some new textbooks do not comply with the new teaching approaches and some textbooks are from the Soviet period. The OPEC Fund11 paid for Russian and English language programs and for printing of 1,345 million copies of 14 textbooks. The Government Program on Computerization of Elementary and Secondary Schools for 2003-2007 was adopted with the purpose to introduce new information technologies. As of today, computer classes were arranged in 594 schools, which are equipped with 9,412 computers.

There are 4 institutions for teacher retraining. However, they have not been operating for lack of funds. International donors support local initiatives and activities of such institutions to conduct of small-scale field-courses. The Step-by-Step Program and the Soros Foundation arranged a workshop on training of 76 teachers and tutors of pilot elementary schools in June-August 2003. German Agency on Technical Cooperation conducted training for 23 elementary school teachers. Local NGOs established programs to upgrade skill of pedagogical staff. These are worthy yet very inadequate programs. Preliminary assessments of international institutions show that there is shortage of more than 10 thousand teachers at all school levels.

Vocational schools are subordinated to the MLSP. Secondary special educational institutions are subordinated to the MOE. Vocational schools and secondary special educational institutions do not teach skills for demands of the current labor market. Training of students in vocational schools remains focused on planned economy curricula, which still envisages placing students in guaranteed employment at certain enterprises. Since 1991, the number of students in vocational schools decreased from 34 thousand to 25 thousand. Secondary special educational institutions focus only on professional and academic training of middle level professions in

\footnotetext{
${ }^{11}$ Organization of Petroleum Exporting Countries.
} 
education, health and several other technical professions. The number of these students decreased from 41 thousand to 25 thousand.

The PRSP, in the short-term, targeted the vocational schools for rehabilitation and retooling, drafting of new curricula and programs, and assistance to students from poor families. In 2002, the MLSP spent 255 thousand Sm. for these purposes. Outside the state budget, the German Embassy and NGO Sadr provided assistance to 4 vocational schools of Tavildara, Tajikabad areas and Dushanbe.

The problem of multiple authorities managing the programs in sectors applies to education sector as well. Many issues in the sector should be coordinated by a single institution. Rapidly growing young population is an added burden to the already limited resources in the sector. The number of students in the system is expected to increase to 850 thousand by 2015 .

\subsubsection{Social protection}

Main PRSP measures on social protection areas during the reported period were aimed at rehabilitating facilities in the sector, providing cash compensation payments and increasing the amounts of pensions.

In 2002, of the twelve facilities in the social protection sector, which were designated for repair, only one pensioners' home was rehabilitated. In 2003, state budget allocated 565 thousand Sm. for these rehabilitation purposes. The MLSP spent 300 thousand Sm. for Kharangon-Varzob area home for war veterans and pensioners, 60 thousand Sm. for Batosh hostel, 24,600 Sm. for Pendjikent hostel, 60 thousand Sm. for boarding school for the disabled in Dushanbe, 44,600 Sm. for Gissar hostel, and 69 thousand Sm. for Vose hostel. Other plans to create day centers in cities and districts for the disabled and pensioners were delayed for lack of funds. The Turkish International Cooperation Agency (TICA) will build one such center. The management responsibilities over the social protection facilities reside with various government bodies. This fragmentation of responsibilities is seen as the main reason in the inadequate service provision to the elderly, the disabled, the women, the children, and the homeless.

Under pilot projects, in 2002, children from the poorest families received cash allowances equal to $6 \mathrm{Sm}$. per quarter. This has allowed implementation of broader payments of targeted cash compensations to $20 \%$ of the poorest families having school age children. Meanwhile, the payments mechanism working through school committees ensured transparency and better monitoring. In both 2002 and 2003, 292,500 school children were covered under this program.

The GRT developed and introduced the mechanism to approve and pay monthly allowances to qualified consumers as cash compensations for increased electricity and gas expenses to reduce their burden. This mechanism compensates families, whose aggregate incomes meet criteria of earning less than the average wage in a region or town. For this purpose, the state budget allocated 12 mill. Sm. in 2003 and 20 mill. Sm. in 2004. For its implementation, the committees from local authorities and community representatives were set up to monitor the entitlements of compensations and their targeted uses. The practice, however, has shown that the mechanism is inefficient due to the complicated system of identifying beneficiaries and inactivity of the committees. The GRT established Working Groups to clear up the issue. Jointly with the WB, the mechanism is sharpening focus on the needy families and rationalizing the procedures of the submissions of applications. 
During the reporting period, other measures in social protection sector were the increases in the sizes of wages and pensions. As of January 2002, the salaries and wages of the employees in the public budget institutions and organizations were increased by $40 \%$. In April 2002, by Presidential Decree, the salaries and wages were increased once again, by $20 \%$. Accordingly, the pensions were raised. Since September 2002, pensions for the WWII veteran invalids have grown by $20 \mathrm{Sm}$. As of June 2002, the minimum pension is $5 \mathrm{Sm}$. and the maximum pension is $70 \mathrm{Sm}$. The amounts of worker pensions, who retired before 1999, were recalculated using new adjustments. The current minimum wage is $5 \mathrm{Sm}$., average wage is $39.9 \mathrm{Sm}$., and average pension is $12.24 \mathrm{Sm}$.

Table 14. Average wages and average pensions, (1999-2003)

\begin{tabular}{|l|c|c|c|c|c|}
\hline & $\mathbf{1 9 9 9}$ & $\mathbf{2 0 0 0}$ & $\mathbf{2 0 0 1}$ & $\mathbf{2 0 0 2}$ & $\mathbf{2 0 0 3}$ \\
\hline Average wage & 11.61 & 15.57 & 23.50 & 32.50 & 39.90 \\
\hline Average pension & 3.53 & 4.06 & 6.01 & 9.48 & 12.24 \\
\hline
\end{tabular}

Source:, SSC, SPF

Decision of reforming the social insurance $\sim \mathrm{d}$ pension systems was adopted by the Government in 1999. Implementation of this measure is delayed for lack of funds. The draft investment project on introduction of the personalized registration and building of the information system is in the PIP 2004-2006 and needs further elaboration in order to qualify for financing.

In Tajikistan, domestic migration processes include population resettlements resulting from voluntary movements away from unsustainable agricultural areas as well as from the effects of natural disasters. Many locations are highly vulnerable to floods, landslides, avalanches, and mudflows.

In 2002, a plan to resettle 1,716 households, from mountainous areas to lowlands was drafted. In general, each household, to accommodate its resettlement, receives about 100-300 Sm. in grants and around 2,000 Sm. in concessional loans. Following resettlements, both the voluntary and the environmental migrants usually face continuing problems caused by inadequate size land plots, lack of basic infrastructures in transport, power, communications, and water supply.

Overall, in 2002, the state budget allocated $360,000 \mathrm{Sm}$. for concessionary loans and 38.6 thousand Sm. for one time grants to resettle 1,287 households. In the first six months of 2003, the state budget allocated 95,400 Sm. for soft loans and 5,790 Sm. for one-time grants for resettlement of 318 households. There was no assessment whether these funds were adequate for the needs of the households.

\subsection{Sustaining economic growth}

The GRT believes that rehabilitation of basic infrastructure, in the sectors of energy, transport, telecommunications and water management systems increases productivity and economic growth in all sectors. The PRSP recognizes that basic physical infrastructure provides access of the poor to water, electricity, communication, and transport. Improved physical infrastructure facilitates communication, information dissemination, access to markets, competition and increased in private sector activity, and delivers public social services such as education and healthcare. Programs on rehabilitation of physical assets of the infrastructure sectors are developed mainly under PIP from donor financing. 
The need to rehabilitate physical assets motivates taking measures to improve financial conditions of enterprises in utility services. The GRT has introduced price adjustments to cost recovery levels in electricity, natural gas, water and telephone services. Other measures to improve the financial situation of infrastructure enterprises included reduction of arrears. High levels of accounts receivables continue to exist in the infrastructures sector.

The restructuring of utilities and infrastructure management systems has been on the GRT policy agenda for some time. However, the changes have been difficult to realize. The role of state in economic sectors remains widespread. Privatization and financial restructuring in infrastructure sectors are progressing at a pace, which prolongs the obvious unsatisfactory status quo.

\subsubsection{Water resources}

The Housing and Municipal Services responsible for the maintenance of the system claims that the existing water supply and water discharge systems are in the state of emergency. In the better part of last two decades, the systems have not been properly maintained. The state budget allocations are inadequate to maintain the system even on emergency bases. Water supply and water intake systems, pumping stations, water reservoirs and water discharge systems do not comply with technical and health standards. Many portions of the networks are in need of replacement.

According to the WHO, $60 \%$ of all infectious diseases are caused by contaminated water. The poor physical state of water supply infrastructure is often the reason for breakouts of typhoid, dysentery, and other diseases. The PIP 2004-2006 enumerates many projects, which describe water systems rehabilitation requirements. The GRT is designing an approach to water supply to agriculture and to the population based on proper costing and rational use.

In conjunction with the exhausted physical infrastructure, the character of water resources management system remains fundamentally unchanged from economy's pre-transition period. Water supply management system is administered by multiple levels of governments. There are overlapping areas in the oversight authorities of the MOET, Agency on Antimonopoly Policy and Support of Entrepreneurship under the Government, Ministry of Water Resources and Land Reclamation, and local governments. Also, the Housing and Municipal Services, sanitaryepidemiological stations, Ministry of Nature Protection, and local governments share the functions of quality control and monitoring. Each institution has authority to sanction violations. However, the bases for evaluating and validating infractions, such as the testing laboratories, are not operating.

There have not been new innovative solutions to the growing management problems. System management reform should become a part of sector policy. In practice, local governments can provide services better because they are usually better informed of the needs of the population. It would be expedient to transfer water supply service functions exclusively to the local governments. Intergovernmental reforms to distinguish the responsibility and authority between local and central government bodies would guide the change in water resources management. 


\section{4,4.2 Irrigation and agriculture}

Agriculture in Tajikistan depends heavily on irrigation. Large segments of the irrigation system are based on pumped irrigation. The costs of electricity for pump irrigation are several times higher than the costs for gravity irrigation. The technologically intensive irrigation system, with high maintenance costs (expensive parts and skilled labor) and high electricity costs have become unsustainable. Frequent failures of equipment lead to frequent system stoppages. The Ministry of Water Resources and Land Reclamation asserts that the system is working at $60 \%$ capacity. Soil productivity has suffered from inability to maintain the irrigation system, intensive farming, and flawed system management. About $15 \%$ of the irrigated land suffers from water logging every year, which contributes to soil salinity. The amount of arable land shrinks every year. Annually, about 50 thousand hectares (about 1\% of all agricultural lands) of cultivated land are exposed to different degrees of desertification.

The GRT considers rehabilitation of irrigation system a high priority. Efforts to secure funds from both domestic and external sources for rehabilitation and institutional capacity building in sector management are part of GRT reforms. However, GRT has not attempted to create water use associations. Many organizations have not yet submitted specific reform implementation plans as was prescribed in the original PRSP Matrix. These systems reform actions are under-girded by land reforms, which in turn would lead to improved management of the irrigation infrastructure. The GRT investment projects are aimed at rehabilitation of irrigation and drainage constructions, construction of rural water supply, agricultural support services for newly organized farms, and developing management capacities of the Ministry of Water Resources and Land Reclamation and local organizations.

In the agricultural extension service areas, where public sector activities are most justified and required, many activities are neglected. Measures to promote plant protection and quarantining system remain unimplemented. Today, there are 4 partially functioning bio-laboratories remaining from the 50 fully functioning laboratories in 1992. Integrated and biological methods for pest control are not practiced. Individual farms are responsible for pest and weed control and quarantining of diseases. Currently, there are no mechanisms for information dissemination to and feed-back from the agricultural producers. In the veterinary sciences, departments under MO A are inadequately equipped to provide for a healthy industry in cattle fanning. The MOA concluded that up to $80 \%$ of veterinary stations and laboratories in Khatlon and Rasht Valley require modernization. The GRT is trying to introduce privatized veterinary services to alleviate the shOftages.12 The GRT designed a program to promote the development of private veterinary services. Accordingly, 20 private veterinary pharmacies were created. The management of the veterinary system is also segmented. It functions in three regional structures and under various veterinary hospitals, veterinary stations, laboratories and experimental stations. Functional rationalization of the sector is necessary.

\footnotetext{
${ }^{12}$ A draft Law on Veterinary Services to promote private veterinary activities was submitted to the Parliament.
} 


\subsubsection{Energy}

During the reporting period, PRSP objectives were sector restructuring, privatization, arrears reduction, and cost recovery pricings. In the sector restructuring process, transforming Barki Tojik and TajikGas into Joint Stock Companies was one of the goals, which did not occur. Increased electricity prices, to recover costs, were introduced in April 2003. Stepwise pricing is applied to four groups of consumers. In addition, seasonality in demand was introduced to pricing. Budget organizations and private users receive the lowest rates. Prices on imported natural gas were reset in July 2003.

Accumulated accounts receivable in the energy sector are paid according to monthly schedules agreed between the supplier and consumers of electricity and gas. A schedule of repayments by the major electricity consumer TADAZ to the OJSHC "Barki Tojik" was approved in March 2003. Arrears in electricity payments continue to increase.

\subsubsection{Transport}

During the reported period, PRSP objectives were sector restructuring, infrastructure rehabilitation, improvement of financial status of transport enterprises, adjustment of pricing including availing inexpensive travel access to the poor.

Transport enterprises restructuring did not take place in the reporting period. There were no actions to facilitate cheaper transportation modes to the poor. In the infrastructure rehabilitation area Murgab-Kulma Pass highway construction was completed. Two other projects, the construction of the Shagon-Zigar highway and the Shkev-Zigar road are under construction with much delay in their schedules. The main reasons for the delays appear to be lack of equipment, high cost of materials and bad labor management. Presently, only the project on rehabilitation of the Baypaza landslide is being implemented on schedule.

\subsubsection{Communication}

The economic rationalization of the telecommunications sector also relies on sector restructuring, cost recovery pricing adjustments, and infrastructure upgrading. The telecommunication sector restructuring work has started. Proposal to establish an independent, Agency on Regulation of Telecommunications was drafted. However, in 2003, there has not been any forward movement to activate this agency.

Prices on domestic and international communication services were increased on December 2002. In February 2003, international telephone call rates were reduced to increase subscribers. In order to reduce the burden of increased prices to the poor population, certain consumer groups and poorer districts receive subsidies from the state budget to cover their costs of telecommunication servIces.

To reduce arrears, stricter measures to collect payments for communication services from the budget institutions have been introduced. According to the Ministry of Communication, outstanding arrears in telephone services were reduced by $5 \%$ to 9.4 million Sm. as of July 2003. In pricing of postal services, the Ministry of Finance is considering the costs of providing free mail service to military. 
Modernization of the telecommunications sector is implemented under a loan extended by the EBRD (USD 13 mill) and the Swiss Government Grant (USD 2 mill). Currently, work is under way replacing the equipment of telephone systems in Dushanbe with the capacity of more than 100,000 subscribers and laying down SDH transmission system ring of optical fiber cables in Dushanbe.

\subsection{Environmental protection}

During the reporting period, the GRT evaluated on-going environmental protection activities (conservation, reforestation), implemented regulations, sought alternative energy sources, and adopted new legislation and programs (Attachment 2). The GRT realizes that issues, which impact the environment detrimentally, impact the poor more than proportionately.

Between 1992 and 2002, the decline in size of forests is estimated at 12-15\%. Main reasons are illegal deforestation and extensive cattle pasturing and overgrazing. The state budget allocated 2,041 thousand Sm. in 2003, and 2,370 thousand Sm. in 2004 towards protection of natural resources. For reforestation, in 2003, the budget spent 659 thousand of Sm. and in 2004, plans to spend 940 thousand Sm. Currently, there are 4 nature preserves, 14 game reserves, and 2 National Parks in the country in order to preserve Tajikistan's flora and fauna and their ecological system.

The environment rehabilitation in the Gissar Valley and the implementation of National Strategy on Management the Natural Disasters were delayed for lack of funds and lack of technical capacity.

In the last few years, the amount of reliable electric power supply to the rural population from traditional sources has been declining. Tajikistan has potential for generating alternative energy, such as solar energy, wind power, bio-energy, and geothermal waterpower for these communities.

The Academy of Sciences estimates that the use of solar energy could meet $10-20 \%$ of the energy needs of the country. Currently, the Academy of Science is conducting studies on the use of solar energy and is developing experimental solar devices. The use of wind power is promising in some regions, where the steady wind speeds are faster than $5-6 \mathrm{~m} / \mathrm{sec}$ at ten meters elevation from the ground. The most promising bio-fuel power generation in the country is production of bio-gas through anaerobic fermentation of liquid waste of cattle. Today, population in some regions is actively using some homemade bio-energy generation devices for producing bio-energy.

In the context of addressing the climate change problem, small hydropower stations are of the greatest interest. Analysis shows the economic efficiency in the use of small HPSs! in the mountainous regions of the country. In some mountainous areas with the assistance of international organizations a number of HPSs were constructed, which supply electricity to several households. However, there are no plans to expand these activities yet.

\subsection{Tourism}

The GRT considers tourism industry in the republic as having considerable capacity for growth, job opportunities and income generation. 
Expansion of tourism services relies on private initiatives. The MOET develops tourism sector public policies. The recent PRSP policies to revive international tourism included ensuring easier entry to the country, improving existing tourist and sanatorium-resort facilities, and attracting investments by using the name recognition of the Great Silk Road. The most popular types of international tourism have been in mountaineering, ecological tourism, sightseeing tours, horseback riding, biking, and river boating and rafting.

Table 15. Forei2n visitors in Tajikistan (1996-2003)

\begin{tabular}{|c|c|c|c|c|c|c|c|}
\hline & 1996 & 1998 & 1999 & 2000 & 2001 & 2002 & $\begin{array}{c}6 \text { months } \\
2003\end{array}$ \\
\hline Number of visitors & 700 & 2,100 & 4,500 & 7,673 & 5,200 & 6,314 & 5,800 \\
\hline
\end{tabular}

Source: $M O E T$

During the reporting period, to promote easier access to Tajikistan, visa regulations were simplified, the time for their review and approval was reduced, the Ministry of Foreign Affairs has set up a Consular Bureau at the Dushanbe airport, new regulations were adopted to open significant areas in GBAO, and visa discounts for groups were introduced. Activities of Tajik firms in international tourism fairs, in the World Tourism Organization events, and in putting out advertisements and websites created a positive image of Tajikistan and built confidence and trust in Tajik tourism products. Participation in international events conducted by WTO, ECO, and UN contributed to opportunities for business consultations and for training. Successful negotiations with foreign tourism firms were held and eight agreements were signed. Earlier agreements with the Russian Federation, China, and countries of the Central Asian Economic Union are being successfully implemented. The annual CIS competition on rock-climbing and extreme tourism was arranged in the Fan Mountains and is now regarded as a reputable international competition. In 2003, Tajikistan was presented in Berlin and Hong Kong International Fairs.

The domestic tourism industry has also been growing. The GRT recognizes Varzob, Boljuvon Districts, and Romit Gorge as special zones for recreation and health spa services. They are targeted for private sector initiatives for rehabilitation of existing facilities and building new physical therapy and rest centers. In 2003, the demand exceeded the supply of these services for the first time in many years.

The Tajik State Arts Institute started a department of tourism management in 1999 in anticipation of the growth of the sector. Currently, thirty students are enrolled in the program. In 2003, Dushanbe City has established affiliation with the Russian International Tourism Academy. There will be acute shortage of expertise in the sector in the near term. By all indications, the tourism sector will grow slowly. The sector infrastructure does not yet comply with the international standards and requirements to become the profitable soon without large investments. To fully identify tourism sector potential and possible income gains, a study would be advisable. 


\section{Challenges in the PRSP implementation}

\subsection{Monitoring and evaluation}

The PRSP Monitoring Department within the Office of the President was established to ensure monitoring and evaluation of the PRSP implementation. 13 One of the main tasks of the Office of the President is to ensure coordinated operations and interaction of the state organs.

Departments of the President's Administration operate under the leadership of the President of Tajikistan (Chairman of the Government) and are subordinate to the Head of President's Administration. Prime Minister of Tajikistan and his deputies supervise the activities of the departments, which ensure execution of the powers of the Government in the relevant trends of domestic and foreign policies.

The PRSPMD Procedures introduce a decentralized system with distribution of functions and responsibilities, including cooperation mechanisms between various institutions. It is expected that PRSPMD will lead the monitoring and evaluation system, which includes the State Statistical Committee, line ministries and agencies, local authorities, units in the President's Administration, and public associations.

PRSPMD tasks include:

- monitoring of the PRSP process, including monitoring the distribution of funds through the public budget and PIP for the projects indicated in PRSP;

- defining institutional functions of monitoring system;

- processing and consolidating information obtained through monitoring process from public entities and other organizations;

- discussion of poverty trends with representatives of government and NGOs;

- dissemination of the results of monitoring and evaluation;

- improvement of monitoring indicators;

- designing the proposals on improving measures and actions for their implementation, based on the experience and lessons learned;

- preparing analytical materials on the status of sectors, drafting proposals for their development, evaluating effectiveness and comprehensiveness of measures;

- preparation of the annual progress report on results of PRSP implementation;

- creating website and upgrading information on PRSP monitoring and evaluation;

- coordination with international organizations on issues related to main PRSP and MDG trends;

- regular interaction and consultations with the stakeholders, including PRSP authors, members of the Parliament, public organizations, international financial institutions to identify and implement the required institutional measures and following up PRSP monitoring and evaluation results;

\footnotetext{
${ }^{13}$ Termns of reference of the new department are set forth in Regulations approved by the President of Tajikistan in May 21, 2003 "On Procedures of Monitoring and Evaluation of Poverty Reduction Strategy Paper"
} 
involvement of analysts to the monitoring process to examine the problems identified during monitoring,

Figure 1. PRSP Monitoring Department within the structure of the GRT (2003)

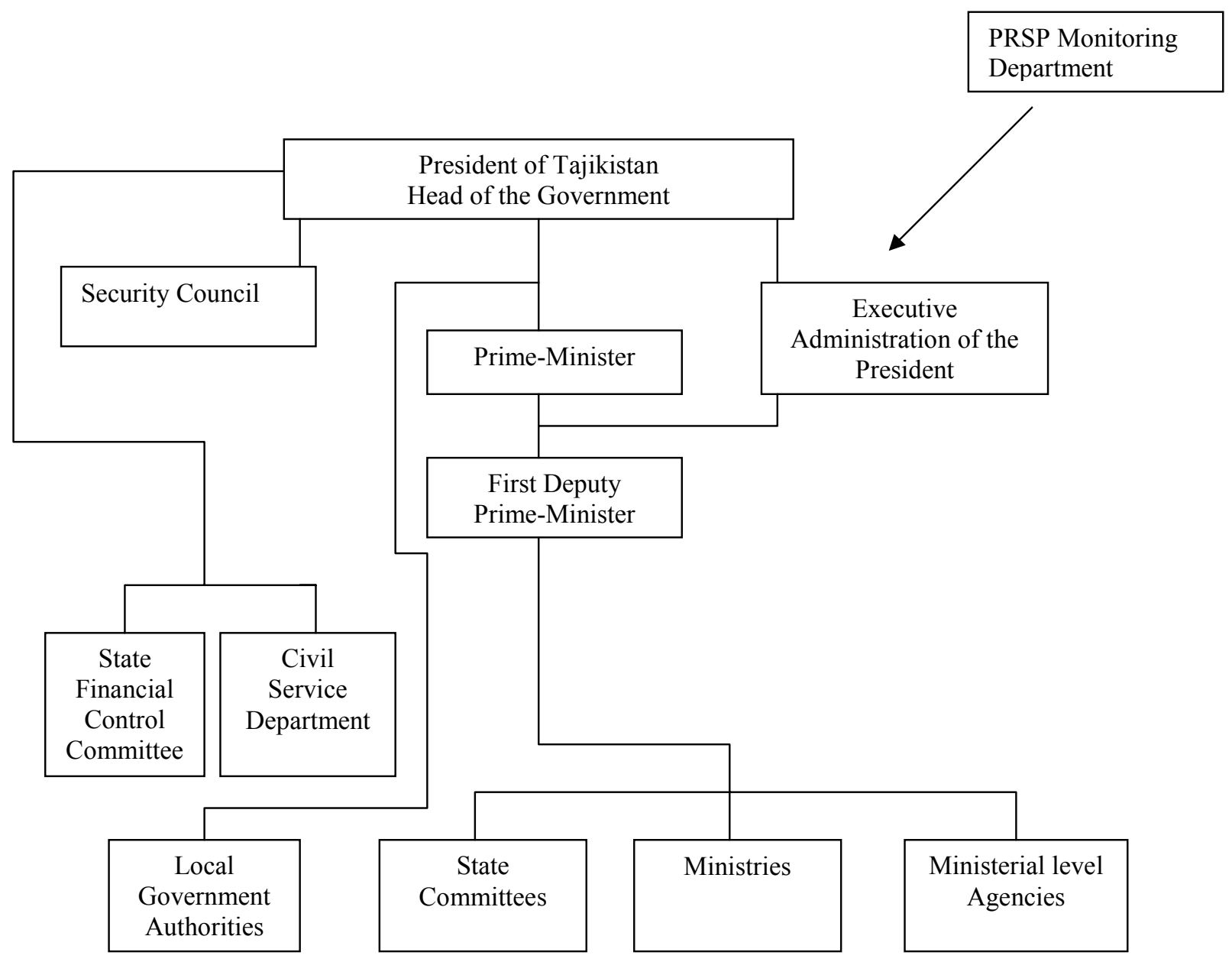

The proposed institutional mechanism for poverty monitoring provides important roles for both the GRT units and CSOs in the process of PRSP monitoring and evaluation, The PRSP implementation will be an iterative process, Identifying priorities, targeting poverty alleviation measures, measuring progress and evaluating effectiveness will evolve, The broad set of participants will have a better chance of success in implementing the PRSP than to a narrow set of participants, Increasing public awareness on the poverty reduction strategy implementation through the network of public associations in various regions will make implementing of monitoring and evaluation more effective,

The Expert Consultative Group (ECG) is one of the main links in the system of monitoring and evaluation, The ECG members include PRSPMD, ACU, MOP, MOET, MOH, MOE, MLSP, donor organizations, international NGOs, and local NGOs, The ECG is chaired by the State Advisor to the President on Economic Policy, 
Figure 2. Coordination of institutions for PRSP monitoring

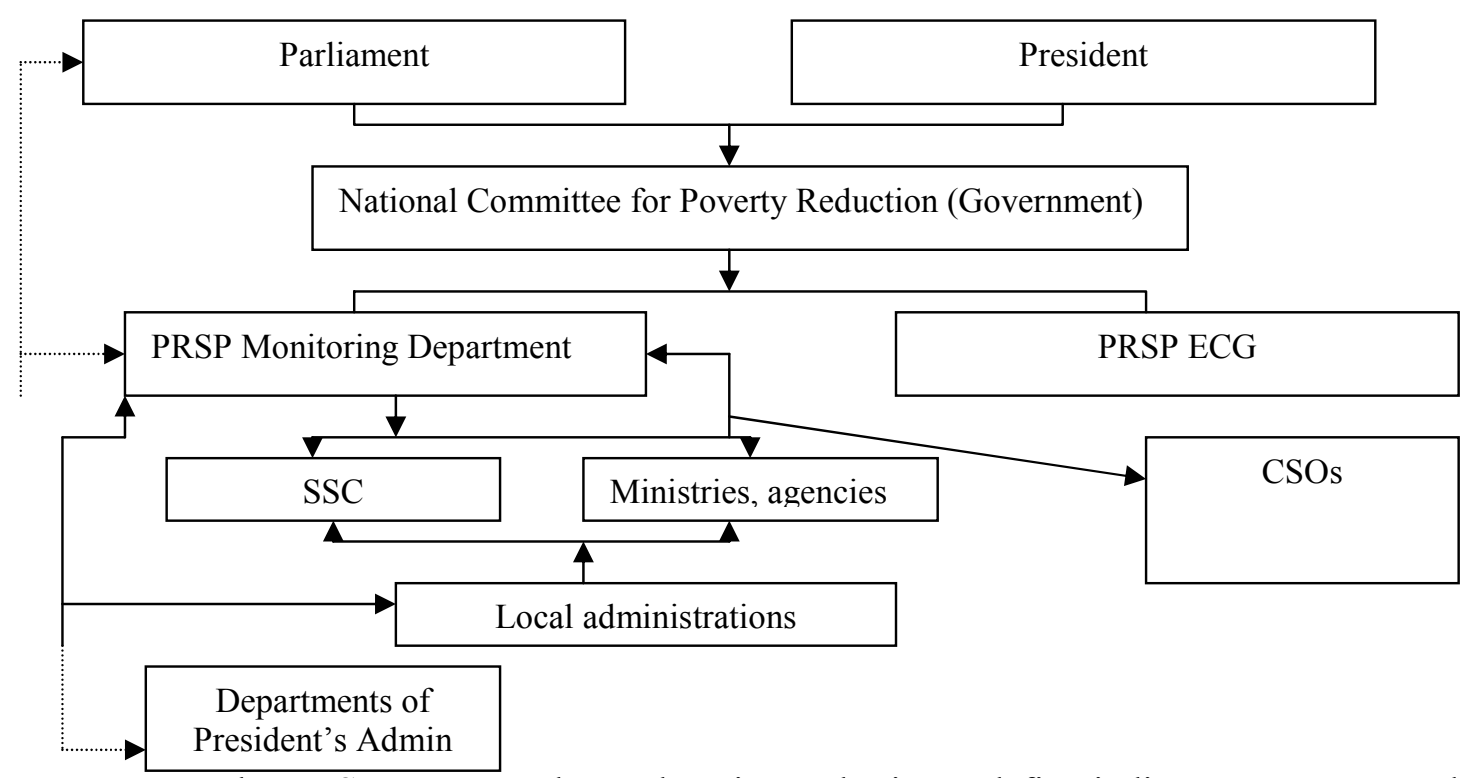

The PRSPMD Procedures also give authority to define indicators to measure the progress in poverty reduction. The design of indicators will consider the coordination of institutions in data monitoring and data collection frequencies. Besides collating data on intermediate and final indicators, other proxy instruments to monitor the progress of poverty reduction will be implemented as required. Initially, there are 94 indicators, which will be integrated into measurement and evaluation process. An important procedural matter is the facilitation of information sharing and flow. If monitoring information is not distributed widely and in a timely manner, the presence of that information does not serve a purpose. The PRSPMD and other agencies responsible for manipulating information should have greater access to documents and data.

\subsection{Technical assistance needs}

PRSP implementation will rely on technical capacity building as well as financial support. The capacity building is needed at all levels of implementation process. The prioritization of PRSP policies, targeting indicators to measure progress in the poverty reduction and putting in place agencies to collect reliable data are the first stages in implementation. We are in the process of resolving the first two tasks. The third part is the data collection system, which currently is very weak. A design of statistical data system and a reporting mechanism with integrity are required. The PRSP monitoring partner agency SSC is receiving Trust Fund technical assistance to upgrade its capabilities in this regard. Other technical assistance, under PRSP Trust Fund Grant is also available to involve budget organizations, local authorities, and the CSOs to contribute in collating data on targeting indicators. The Grant will assist also in the coordination work of PRSPMD.

Current available data from national sources have been not-well defined, mostly discontinuous, and irrelevant to the poverty reduction measurement requirements. Already, some of the designs and action plans, which relied on these data, served the PRSP process in less than an 
ideal manner. In the reporting period, ADB, WB, UNDP, UN ESCAP ${ }^{14}$ and various NGOs have conducted surveys and given technical support, which have become the starting point of our monitoring and evaluation work. In the foreseeable future, we expect this support to continue, both to bolster our database as well as give capacity to our institutions. These institutions include PRSPMD, statistical agencies, budget organizations, local authorities, the Parliament, local NGOs, and the media. At its most elemental level, the capacity building refers to information dissemination and creating a feed-back system with all the stakeholders.

\subsection{Role of stakeholders}

In the reporting period, the public was not actively involved into the process of PRSP monitoring and evaluation. During the initial stages of the PRSP implementation, not all components have been put in place. However, the proposed institutional monitoring and evaluation mechanism provides for the participation of CSOs. The coordination of CSOs and their crosspollination of their expertise would yield externalities. The establishment of ECG and its ability to communicate through its membership to wider population and to the larger donor community is hopeful.

Table 16. hotlin conferences (2001-2003)

\begin{tabular}{|l|c|c|c|c|}
\hline & 2001 & 2002 & 10 months 2003 & TOTAL \\
\hline $\begin{array}{l}\text { Televised hotline } \\
\text { conferences }\end{array}$ & 650 & 700 & 800 & 2.150 \\
\hline
\end{tabular}

Source: PRSPMD.

The media has been increasingly involved in providing platforms for the public to offer opinions on poverty and its causes. In recent years, number television conferences on economic and political issues were conducted. The governmental officials participate in television debates to address current affairs. However, today such events are not conducted on a regular basis. Public also has had opportunities to question the actions of public institutions by the use of "hotline telephones" of various agencies. Still, there is not an effective public opinion feedback mechanism, following publications of draft GRT decisions in mass media, which could provide wider participation of the population. Various opinions of readers are not published and frequently are not taken into account when finalizing decisions by the GRT.

The lack of access to communication facilities, TV, and radio for people, who live in remote mountainous areas, is a practical problem for information dissemination and feed,back mechanism. The GRT is taking actions, such as the program "Mavji Somon 2005,' to expand outreach of the national TV and radio programs. To fully extend media coverage nationally requires substantial investments.

As for the participation of the Parliament in the PRSP implementation, the designed mechanism of interaction is not functioning well. The members of the Parliament receive information of PRSP implementation process only in final reports. After the initial activities of

\footnotetext{
${ }^{14}$ UN Economic Commission for Asia and Pacific Region.
} 
PRSP preparation, the members of the Parliament have remained uninvolved. The perception that the PRSP is a program solely under the purview of the executive branch is mistakenly perpetuated.

\subsection{Donor aid coordination}

Tajikistan has been receiving international donor aid and assistance since 1992. Many structural and institutional reforms have taken place since then. The issue of aid coordination, however, has gotten more complicated and aid management remained an issue, which needs much attention in order to increase efficiency of donor assistance. The great need in donor aid to reduce poverty in Tajikistan combined with the limited resources among the donors makes aid coordination an imperative.

In 2001, the GRT created the ACU in the Office of the President to improve the coordination and to ensure effectiveness of donor assistance. However, within the GRT, the donor assistance is monitored and evaluated at varying degrees among the MOET, MOF, and ACU. The GRT has been more successful in monitoring the funds from multilateral donor organizations than monitoring the funds from bilateral donors and NGOs. The donors usually do not coordinate their activities well with each other. Each organization operates on various budgetary cycles, scales and duration of projects, and has varying rules of accountability and control. Quite often these agencies install fragmented programs, which may not fully be integrated to GRT policies. These result, in duplication of some donor projects in certain areas and sectors. Also the potential of projects is not built upon on the experiences of other projects. Many foreign-aid financed projects are carried out by international and local NGOs. They, by their constitution, function independently from the state and frequently have been reluctant to inform on the progress of their projects.

The GRT suggests that the issue of coordination of the external aid is clarified. A database would determine the volume of the external assistance allocated by various agencies and also the detailed breakdown by regions and sectors. Quarterly reports would highlight progress. Reports on project implementation would reveal shortcomings at any stage of realization of the projects. This would give opportunity for readjustments to satisfy all stakeholders, including the civil society opinions. In this context, the ECG would serve a pivotal function in liaising between GRT poverty reduction policies and donor assistance. The ECG can strengthen the broad participation in decision making, project relevance, improved transparency, and better aid coordination. 


\section{MATRIX OF GRT POLICIES FOR POVERTY REDUCTION FIRST YEAR IMPLEMENTATION}

(Reporting period June 2002 - December 2003) 
MATRIX OF GRT POLICIES FOR POVERTY REDUCTION: FIRST YEAR IMPLEMENTATION (2003)

\begin{tabular}{|c|c|c|c|c|c|}
\hline \multirow[t]{2}{*}{ MEASURES } & \multicolumn{3}{|c|}{$\begin{array}{l}\text { Implement } \\
\text { Level }\end{array}$} & \multicolumn{2}{|c|}{ Basis } \\
\hline & 1 & 2 & 3 & A & $\mathrm{B}$ \\
\hline \multicolumn{6}{|l|}{ ECONOMIC MANAGEMENT } \\
\hline Tax collection system improvement and strengthening of tax administration (focusing on main taxpayers) & $\mathbf{X}$ & & & & \\
\hline Adoption of law on introduction of changes and amendments into the Tax Code of RT in terms of minimization of elements distorting tax system & $\mathbf{X}$ & & & & \\
\hline Submission of proposals on modification of cotton taxation & $\mathbf{X}$ & & & & \\
\hline Implementation of data computerization system including establishment of regional network & & $\mathbf{X}$ & & & \\
\hline Output targeting of budget expenditures & & $\mathbf{X}$ & & & \\
\hline Establishment of PIP Unit & $\mathbf{X}$ & & & & \\
\hline $\begin{array}{l}\text { Monitor budget revenues generated by } 4 \text { districts (Shaartuz, Nov, Leninskyi, and Vanj) that introduced single land tax and evaluate feasibility to } \\
\text { introduce it nationwide in } 2004\end{array}$ & $\mathbf{X}$ & & & & \\
\hline Adhere to stipulations of the Law "On State Budget of in 2003" for reducing sales tax on cotton and replacing with VAT on cotton & $\mathbf{X}$ & & & & \\
\hline Monetary Policy & $X$ & & & & \\
\hline Ensuring compliance with International Accounting Standards; & $\boldsymbol{X}$ & & & & \\
\hline Currency management - adoption of Law on Guaranteeing of Individuals' Deposits to support rate of Somoni towards foreign currency & $\mathbf{X}$ & & & & \\
\hline Development of instruction On Procedure of Opening and Maintaining of Bank Accounts of Citizens Legalizing Their Money & $\mathbf{X}$ & & & & \\
\hline Acceleration of implementation of the Law of RT On Amnesty of the Citizens of RT with Regard to Legalization of their Money & $\mathbf{X}$ & & & & \\
\hline Abandoning all activities, including remaining directed credits, not related to core functions of a central bank & $\mathbf{X}$ & & & & \\
\hline Improvement of operations on NBT International Reserves management, credit portfolio quality and augmentation of its yield & & $\mathbf{X}$ & & & \\
\hline Adoption of rules on NBT's open market transactions & & $\mathbf{X}$ & & & \\
\hline $\begin{array}{l}\text { Expanding the number of instruments used for managing short term liquidity (Increase sale of state treasury bills, Provide issue and sale of NBT } \\
\text { certificates, Carry out REPO and reverse REPO) }\end{array}$ & & $\mathbf{X}$ & & & \\
\hline Activating of secondary securities market: (analysis and recommendations) & & & $\mathbf{X}$ & & $\mathbf{X}$ \\
\hline $\begin{array}{l}\text { Tightening of rules on commercial banks operations and actions in deposit increase support (Audits/checks of commercial banks' activities in accordance } \\
\text { with activities schedule, Merger of commercial banks that did not meet prudential requirements by the end of first quarter of } 2003 \text {, Restructuring of } \\
\text { Agroinvest Bank) }\end{array}$ & $\mathbf{X}$ & & & & \\
\hline \multicolumn{6}{|l|}{ External Debt Management } \\
\hline Negotiate external debt restructuring & & $\mathbf{X}$ & & & \\
\hline Ending the practice of providing Government guarantees (for non-concessional loans) & $\mathbf{X}$ & & & & \\
\hline $\begin{array}{l}\text { Enforce the law that gives MOF exclusive rights for external debt management (Develop strategy of further restructuring of external debt based on more } \\
\text { favorable terms taking into account world practice) }\end{array}$ & $\mathbf{X}$ & & & & \\
\hline Conduct detailed inventory of all external debt of Government and state-owned enterprises & $\mathbf{X}$ & & & & \\
\hline Prepare quarterly reports to Parliament on external debt & $\mathbf{X}$ & & & & \\
\hline
\end{tabular}

1 = high, 2 = low, 3 = none; $\mathrm{A}=$ no financing, $\mathrm{B}=$ other (lack of institutional capacity, timing, etc.

CInternational Monetary Fund. Not for Redistribution 


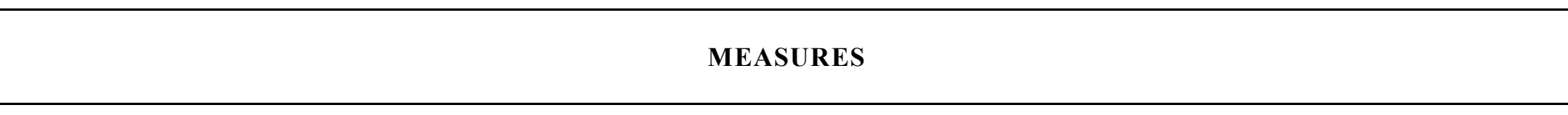

ATTACHMENT 1

Effectiveness of Judiciary

Establish a special group to assess of judiciary and of services provided by judicial bodies and make recommendations on the working conditions

Realization of recommendations for all judicial bodies

Restructuring of executive bodies

Restructure of central executive power bodies

Restructure of local executive power bodies

Identify functions that could be performed by the private sector

Supply public administration bodies that are under restructuring with equipment

Ensuring transparency of public administration bodies' activities

Introduce changes and amendments into existing legislation on expanding communication between public administration bodies and community/people

Reduce tariffs for services of state agencies

Assess stamp duties and other fees/duties in terms of actual expenses of state bodies for rendered services (Establishment of interdepartmental working

commission, analysis of findings and preparation of required proposals)

Coordination of control activities

Develop clearer procedures and single schedule of republican and sector administration activities review, methods of evaluation of outcomes of control

activities, improvement of methods of control activities analysis

Expansion of scope of work for the State Financial Control Committee

Establishment of effective governance system appropriate to market conditions

Review of existing system of wages and wage variation depending on qualification, including impact of taxes

Adoption of legislative acts regulating issues of material incentives, internal regulations and job description of civil servants

Adoption of the Code of Ethics for public servants

Arrangement and preparation of audience to entry into the Institute of qualification improvement to the courses of raising the level of skills

\section{SOCIAL PROTECTION}

\section{Assisting children in poverty}

Submission of evaluation of city and district commissions on compensation payments for 2002;

Evaluation of city and district commissions on compensation payments.

Development of proposals on financing of cash allowances (compensations) payments to attending schools students, using provided for funds in republican budget;

Introduce the position of specialist in staff structure of MLSP to work on issues of cash compensation;

Encourage international organizations to provide technical assistance and conduct seminars (Design of projects on children protection issues and their

submission to international organizations)

Assessment of Law "On indexation of households income taking into account rise in consumer goods and services prices" (11/27/1993)

Develop procedure of indexation

Determine number of street-children and appraise state of institutions

Prepare proposals on the placement of street-children in relevant institutions

$1=$ high, $2=$ low, 3 = none; $\mathrm{A}=$ no financing, $\mathrm{B}=$ other (lack of institutional capacity, timing, etc.

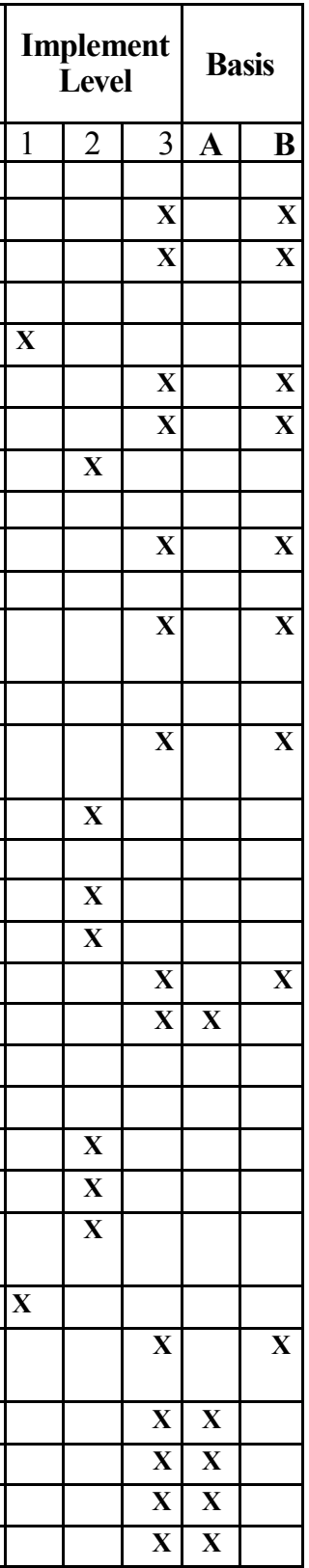

(C)International Monetary Fund. Not for Redistribution 


\section{MEASURES}

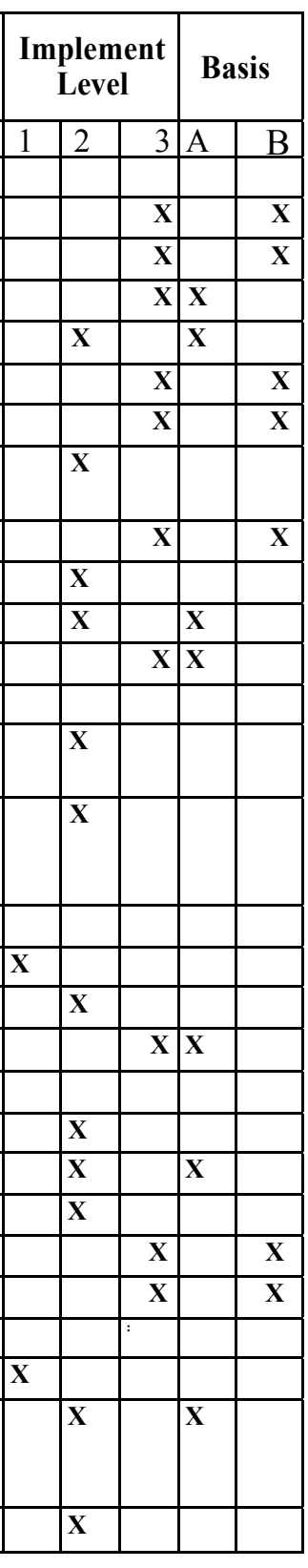

\section{Pension system reform}

Draft new edition of the Law On Pension Provision of Citizens of the Republic of Tajikistan

Draft the Laws 'On Non-government Pension Funds'; and 'On Accumulating System of Social Protection'

Evaluate implementation of actions on arrangement of home delivery of pensions

Develop and submit proposals on establishment of Research Institute on Demographic Processes Development on the basis of Academy of Sciences

Coordinate with international organizations the issues of financing of researches on the Concept of State Demographic Policy issues

Development of project proposal on assessment and development of social sector strategy and finding donors

Review the issue of establishment of Research institute on Social Problems Assessment on the basis of Research Institute of Labor, and Social Problems

Center of the Academy of Sciences

Drafting of the law on social standardization

Establishment of the center on management of information systems of the MLSP

Introduction of automated system of information processing

Review the issue of pension increase through application of adjustment coefficient

\section{Reconstruction and rehabilitation of the buildings and facilities}

Work out rehabilitation/reconstruction needs of institutions for invalids, elderly and severely mentally retarded children (psycho-neurological), Lyceum/boarding school for disabled and poor children

Develop investment program for rehabilitation/reconstruction of sanatoriums, preventive clinics and boarding houses for war and labor veterans

(Develop project of rehabilitation of sanatorium/preventive clinic for war and labor veterans and invalids "Harangon" and project of rehabilitation of

sanatorium/preventive clinic "Yamchun" in Ishkashim district)

Develop new source of funds for specialized institutions

Develop Pilot program at one of the specialized institutions to alleviate their economic difficulties

Allocation of land plots for specialized institutions to be used for auxiliary fanning

Development of projects to be submitted to the Ministry of Defense on supporting specialized institutions in purchasing seeds, cattle, etc.

Social services and assistance to pensioners, invalids and there living below poverty line

Coordinate the issue of creation of daycare centers for poor pensioners with local executive authorities

Creation of new territorial centers in Khorog, Kulyob, Isfara, and Kanibadam towns, and Sarband, Kolkhozabad, Leninskyi, and Rasht districts

Training social workers to provide services at home

Consider issue of preferential taxation of at-home social assistance departments

Consider issue of multi-channel financing of at-home social assistance departments

\section{Rehabilitation and preventative measures}

Develop a program for providing services and prosthetic-orthopedic and other prosthetic goods to invalids

Improve health resort treatment of veterans and invalids (Reconstruction and repair of Research institute on Expert Examination and Rehabilitation of
Labor Disabled and its 60-bed clinics, of the branches of prosthetic-orthopedic plant in Khorog, Khujand, and Kulyob, and of sanatorium-preventive

Labor Disabled and its 60-bed clinics, of the
clinics "Dusti", "Yamchun", add "Romit")

Develop programs on training staff to treat $3^{\text {rd }}$ category invalids

1 = high, $2=$ low, 3 = none; $\mathrm{A}=$ no financing, $\mathrm{B}=$ other (lack of institutional capacity, timing, etc 


\section{ATTACHMENT 1}

\section{MEASURES}

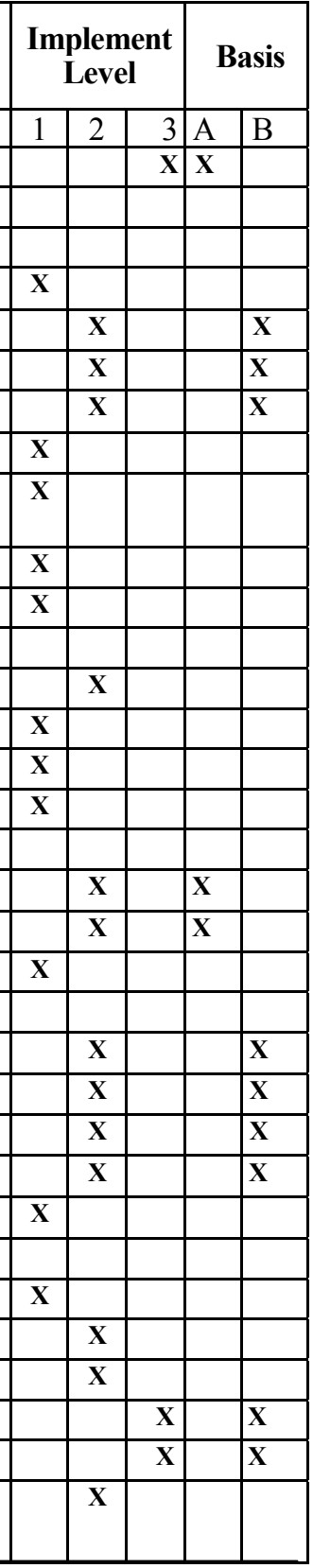

Develop program on the issues of assistance in rehabilitation of activities of training and production center of invalids' society

\section{HEALTH}

Strengthening and development of PHC system

Building capacity of family doctors and family nurses training and retraining facilities

Bring organizational structure of PHC institutions in compliance with approved procedures

Development of standard design of PHC institutions

Development, publication and introduction of manual on PHC institutions management

Restructuring of PHC facilities and rural district hospitals (SUB) in Dangara and Varzob districts

Repair, reconstruction, and construction of PHC institutions of pilot Dangara and Varzob districts, and their furnishing with basic medical equipment,

sanitary vehicles, and radio-communication equipment

Repair, rehabilitation and provision with basic medical equipment of two pilot institution in Kulyob district

Rationalization of medical services, motivation of personal responsibility of the population for their own health: program for Healthy Life Style by 2010

\section{Hospital services reform}

Development of legal framework for restructuring and rationalization of hospitals considering real demand on the sites

Reorganization of the number of SUB into Rural Health Centers of Dangara and Varzob districts

Rehabilitate hospital in Dushanbe

Rehabilitate seven central district hospitals in Sugd Oblast and eight Central district hospitals in Khatlon Oblast

Promotion of family planning and reproductive health care

Arrange for measures on raising people's awareness of family planning and reproductive health issues

Develop access to family planning advisory services

Implement of National program on family planning and of the Law "On reproductive health and reproductive rights"

Improvement of the public health svstem (contagious disease issues management)

Improvement of sanitary and life conditions of population

Intensification of anti-epidemiological activities with international organizations' involvement

Develop proposals on creating of national control laboratory on medicines quality

Elaborate project proposals on development and improvement of sanitary and epidemiological supervision

Draft legislative framework on organization of activities of sanitary and epidemiological service corresponding to market conditions

Development of pharmaceutical infrastructure

Implement the Law of the Republic of Tajikistan "On medicines and pharmaceutical activities", bring legislative consistency to industry

Develop regulations/instructions on pharmaceutical institutions functioning in new economic environment

Develop proposals on improvement of the process of chemist's shop licensing

Appraise prices of the main/basic medicines in order to develop mechanism of their regulation

Develop adequate mechanisms of medicines procurement

Assess country's needs in medicines

$1=$ high, $2=$ low, $3=$ none; $A=$ no financing, $B=$ other (lack of institutional capacity, timing, etc

(C)International Monetary Fund. Not for Redistribution 
ATTACHMENT 1

\section{MEASURES}

Appraise resources of local natural raw pharmaceutical materials

Develop proposals on establishment of a National Laboratory for medicines quality control

Introduction of new health care financing system

Develop mechanism of per capita financing of PHC system

Develop legislative framework for reforms in health care financing system

Raise salaries of health sector employees by $20 \%$

\section{Improvement of human resources management and development system}

Develop proposals to introduce changes and amendments into existing legislation in terms of increasing responsibility of graduates from medical higher

education institutions towards compulsory work at the places of their assignment for minimum three years

Development of programs of phased retraining of management personnel, development of job descriptions on health care facilities management

Develop and submit for consideration the proposals on establishment of health departments in the structure of local executive power bodies in the towns

and districts

Submit proposals to introduce system of training specialists based on regional needs

Assess and establish scientifically grounded approach to identify health care system needs in medical and Pharmaceuticals specialists

Develop quality standards of specialists' training at all the stages of undergraduate and postgraduate education

Appraise composition and structure of medical personnel employment, and on the basis of this appraisal to plan their training

Implement computerized information system at PHC level in Dangara and Varzob districts

EDUCATION

Increase salaries by $20 \%$

Ensure timely payments in the local districts;

Revise legal framework of the system of state and non-state education sector and include the possibility of granting of tax privileges

Develop and submit proposals on mechanisms of self-financing

Rehabilitation of physical infrastructure of education institutions

Assess physical infrastructure of education system and develop norms from minimum standards

Develop criteria for determining priorities for repair/rehabilitation activities

Providing schools with new textbooks, modern visual aids, teaching equipment, and other teaching resources

Print 1,263,000 textbooks with ADB and OPEC help

Determine needs for text books, equipment, furniture, and other technical teaching aids

Develop and approve appropriate mechanism for monitoring the quality of textbooks and quality of their printing

Expand programs of school computerization to introduce information technologies

Establish enterprises school furniture and teaching aids production under the MOE

Revise content of curricula and syllabuses

Improve existing norms taking into account implementation of interactive methods of teaching

Improve curricula and syllabi

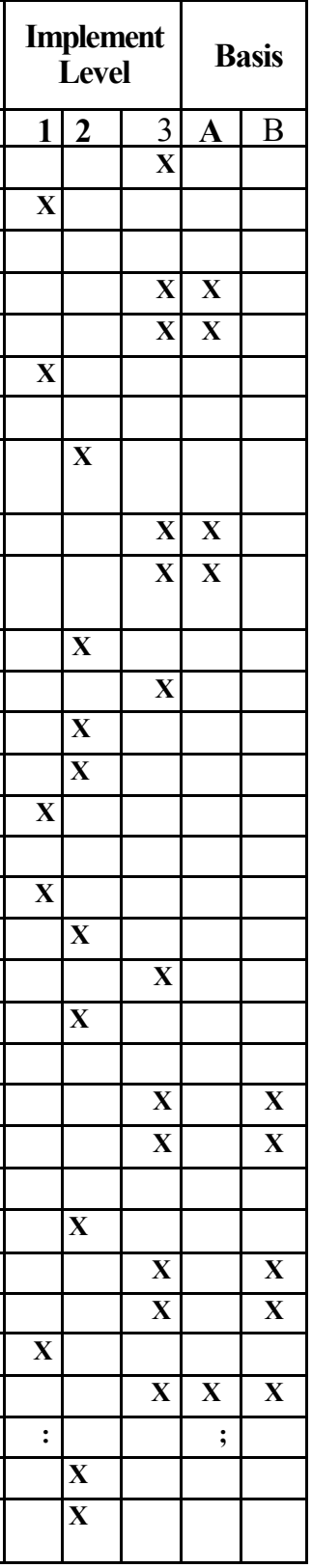

$1=$ high, $2=$ low, 3 = none; $\mathrm{A}=$ no financing, $\mathrm{B}=$ other (lack of institutional capacity, timing, etc . 
ATTACHMENT 1

\section{MEASURES}

Develop criteria for content of teaching-methodical and gaming aids, didactic materials for schools and preschool institutions, prepare draft copy and figure out financing resources

Create conditions for alternative access to education system (develop methodologies)

Revise system of new curricula and syllabuses implementation monitoring

\section{Introduction of new models of teachers training and raising the level of their skills}

Revise current curricula and syllabuses for teacher retraining

Submit proposals on establishment of institute on upgrading qualification of the teachers of pedagogical HEI, and other colleges and institutes

Collaborate with NGOs to develop non-traditional forms of upgrading skills (pedagogical collectives)

Identify needs of existing institutes and submit concrete proposals on their equipping (to strengthen material and skills base of retraining institutes)

Develop action plan for upgrading teachers' qualification ensuring minimum $50 \%$ coverage of the teachers involved in provision with basic education Develop modem programs on the basis of new educational technologies (for HEI)

\section{Improvement of management model}

Define management responsibility of GRT, MOE, departments, local authorities and education institutions in expanding management independence of

education institutions; develop regulations describing functions of MOE, Khukumats and jamoats

Develop monitoring system for new management model

Develop policy regarding the role of non-government structures including NGOs, parents and teachers associations, communities, and private sector.

\section{Establishment of targeted scholarships for poor children}

Provide $20 \%$ of students and children from families with many children and orphans with clothes, footwear, and school writing accessories by the

beginning of academic year

Provide meals for students at elementary schools (1-4 grades)

Develop additional measures on supporting children from remote regions and raising level of their education, including improvements of procedures in the Presidential Quotas

Develop proposals on granting scholarships to poor children and orphans based on needs criteria;

Establish alternative forms of obtaining education for the children coming from refugee families and for older children that do not study at school - to expand coverage area for circumstances of applicability of alternative ways to get educated

\section{Development of professional activity of teachers}

Improve teacher/student ratio in order to increase effectiveness and quality of education

Submit proposals on development of the system of encouragement of "Excellent workers of education" through additional payments to monthly salaries or pensions

Develop of mid-term and long-term Education development program

\section{AGRICULTURE}

Restructure 100 farms in accordance with the Government Resolution \#385, (10/01/02)

Conduct monitoring of ensuring equitable allocation of land of reorganized farms among the workers of these farms

Broad discussion of problems arising in the course of land reform in Republican and local mass media

Conduct seminars traveling to all the regions of the country

1 = high, 2 = low, 3 = none; $\mathrm{A}=$ no financing, $\mathrm{B}=$ other (lack of institutional capacity, timing, etc

(C)International Monetary Fund. Not for Redistribution 
ATTACHMENT 1

MEASURES

\begin{tabular}{|c|c|c|c|c|}
\hline \multicolumn{3}{|c|}{$\begin{array}{c}\text { Implement } \\
\text { Level }\end{array}$} & \multicolumn{2}{|c|}{ Basis } \\
\hline 1 & 2 & 3 & A & B \\
\hline \multirow[t]{2}{*}{$\mathbf{X}$} & & & & \\
\hline & & $\bar{X}$ & & $\bar{X}$ \\
\hline \multicolumn{5}{|l|}{$\mathbf{X}$} \\
\hline \multicolumn{5}{|l|}{$\mathbf{X}$} \\
\hline & $\mathbf{X}$ & & & \\
\hline & $\mathbf{X}$ & & & \\
\hline & & & & \\
\hline & & $\mathbf{X}$ & $\bar{X}$ & \\
\hline & $\mathbf{X}$ & & & \\
\hline & & $\mathbf{X}$ & $\bar{X}$ & \\
\hline & $\mathbf{X}$ & & & \\
\hline & $\mathbf{X}$ & & & \\
\hline & & & & \\
\hline & & $\mathbf{X}$ & $\mathbf{X}$ & \\
\hline & $\mathbf{X}$ & & & \\
\hline & $\mathbf{X}$ & & $\mathbf{X}$ & \\
\hline & & $\mathbf{X}$ & & $\mathbf{X}$ \\
\hline & & $\mathbf{X}$ & $\mathbf{X}$ & $\mathbf{X}$ \\
\hline & & $\bar{X}$ & & $\mathbf{X}$ \\
\hline & $\mathbf{X}$ & & & \\
\hline & & & & \\
\hline & $\mathbf{X}$ & & & \\
\hline & $\mathbf{X}$ & & & \\
\hline & $\mathbf{X}$ & & $\mathbf{X}$ & $\mathbf{X}$ \\
\hline $\mathbf{X}$ & & & & \\
\hline & & & & \\
\hline & & $\mathbf{X}$ & & $\mathbf{X}$ \\
\hline & & $\bar{X}$ & $\bar{X}$ & \\
\hline $\mathbf{X}$ & & & & \\
\hline & & & & \\
\hline & $\mathbf{X}$ & & & \\
\hline & & & & \\
\hline & $\mathbf{X}$ & & & \\
\hline
\end{tabular}

Introduce special courses on land-user rights study into curricula of High School of AIC and Agrarian University

Arrange consulting services on the issues of land-user rights through specially established NGOs

Implementation of Farm Privatization Support Project and Post-Privatization Agricultural Support Project

Consider the issue of investing SLMC with authority to carry out control over distribution of land among workers of agriculture production entities

Bring legislation into conformity with Land Code and adopt new legislative acts on activating land reform

Implementation of Agriculture Rehabilitation and Development Program

Irrigation

Reform of water management system (Development and submission of the proposals on sector reforms)

Drafting of the Law on Water Users Associations and relevant normative and legal acts

Submit outcomes of by-region assessment of existing irrigation system, and priority facilities

\begin{tabular}{l} 
Submit precise proposals on the gradual increase of water and electricity tariffs to achieve complete cost-recovery \\
\hline Im
\end{tabular}

Implementation of investment projects on Dangara valley irrigation and rural infrastructure rehabilitation

Agricultural support services

Information-methodical and consultative assistance through creation of consulting networks and NGOs

Arrangement of training for farmers on correct and effective use of mineral fertilizers and pesticides

Assistance with methodology, organizational and management know-how on farm issues

Consider the issue of creation of information centers in MA divisions to inform cotton producers about world cotton market developments

Consider the measures on encouraging establishment of information and consultation centers for agricultural enterprises

Provide through NGOs and rural self-governance bodies consultancy to cotton producers on design of futures contracts on cotton products and inputs

Consider the issue of effectiveness of partial distribution of pastures and hayfields among households

Development of veterinary service

Develop program of reforming and further development of veterinary services

Develop and submit investment projects on private veterinary services development

Allocation of land plots to private veterinary services in regions and districts for construction of pharmacy clinics

Implement projects on rehabilitation of veterinary services in Khatlon Oblast and Rasht Valley (FAO)

Development of plant protection and quarantine system

Draft normative and legal documents determining the procedure of agricultural production import and export

Activation of quarantine base stations' activities for timely revelation of plants and animals diseases in the regions and assess quarantine base stations

Implementation of pest control project (FAO)

Development of seed-farming

\begin{tabular}{|l} 
Design the procedure of transfer of seed-farms land to Dehkan farms on rent basis with following purchase of seed material at transaction prices \\
\hline Devel
\end{tabular}

Development of processing industry

Prepare for privatization through individual projects of alcohol producing and tobacco processing enterprises

$1=$ high, $2=$ low, 3 = none; $\mathrm{A}=$ no financing, $\mathrm{B}=$ other (lack of institutional capacity, timing, etc.

CInternational Monetary Fund. Not for Redistribution 
Construction and putting into operation of agricultural products processing workshops (tinned food production) in Dangara, Khujand, and Isfara, and workshop for aseptic storage of fresh fruits and vegetables in Cheptura

\section{PRIVATIZATION}

Introduce changes and amendments into Strategic Plan of Privatization

Introduce changes and amendment into procedures for privatization at the auctions and biddings as well as into the regulation on State Property

Management Committee of the Republic of Tajikistan

Create central recorder and network of commercial recorders

Develop and adopt schedule of the sale of assets of non-viable enterprises to be privatized

Draft legal basis for coordination of the issues of incorporation and management of state property

\section{LABOR, POPULATION}

Develop normative and legal acts

Publish book of Comments to the Law of RT "On promotion of population employment"

Create new structure of employment services bodies' management

Train and retrain staff together with ILO; implement ILO training programs

Computerization of social protection agencies

Establishment of single database on job vacancies and unemployed

Initial stage of development and implementation of methodology of generating reports on labor market at the republican and regional levels with creation of

single database

Expansion of vacancies number and intensive involvement of labor resources

Create the network of Social-Business Centers (SBC) to support business initiatives of unemployed

Establish Micro-credits Center under Employment Service

Implement ILO training programs

Expand regional programs

Broad involvement of NGOs and international organizations

Implement within the government program on employment for 2003-2005 targeted sub-programs of women employment

Improvement of labor remuneration organization system

Develop and publish Unified Tariff Schedule (UTS) and Classifier as separate brochures

Reform of vocational education system

Submit proposals on introduction of targeted assistance to vocational institutions students

Development of migration processes

Elaborate and further develop program on voluntary and ecological migration

Training of local specialists

Continue development and adoption of normative and legal acts on migration that were initiated in 2002

Create computer center of State Migration Services (SMS)

$1=$ high, 2 = low, 3 = none; $\mathrm{A}=$ no financing, $\mathrm{B}=$ other (lack of institutional capacity, timing, etc.

(C)International Monetary Fund. Not for Redistribution 


\section{Labor safety and labor protection}

Establish regional units of State Inspection of Labor and Labor Conditions

Train labor protection workers in accordance to recommendations and support of ILO

\section{PRIVATE SECTOR DEVELOPMENT}

Implementation of State Program on Entrepreneurship Support for 2003-2005 - carry out activities within the funds provided for in 2003 budget Develop a mechanism of monitoring

Identify legal procedures to create rural lending and savings associations, and for their relations with banking institutions

Develop proposals on rehabilitation of existing system of Commodity Credit organizations

Develop investments proposals for creation of rural financing systems

Elaborate new legislation and regulations on insurance, on transfers of insurance premiums and determination of sums of insurance compensation

\section{Energy}

Draft normative and legal acts regulating issues of state energy supervision

Implement action plan on gradual introduction of new electricity tariffs that ensure full cost recovery including, in particular, introduce tariff system separately for households, budget organizations and industrial enterprises (in accordance with ADB findings and recommendations)

Implement Action Plan on reduction of Barqi Tojik and SUE Tajikgas accounts receivable and prevention of new debts accrual

Increase collection of fees from energy resources user (electricity: up to $80 \%$; gas: up to $70 \%$ )

Develop and adopt national energy-saving program, its implementation plan, introduction of strict accounting of electric energy consumption

Prepare long-term program of energy sector development, including: Program of restructuring, de-monopolization and privatization of energy sector Completion of the process of transformation JSHC Barki Tojik and SUE Tajikgas into JSC

Rehabilitate Nurek HES, (improve electricity supply to Dushanbe, rehabilitate activities on electricity supply to southern Tajikistan)

Develop of proposals on targeted assistance to poor with regard to review of energy services tariffs structure

\section{Transport}

Bring legal and procedural consistency to the sector according to the Law "On transport"

Development of normative-technical documentation on preferential passenger transport fares for the poor, elaborating the issue of targeted funding Revise tariff structure of freight and passenger transportation by all types of transport taking into account accessibility of transport services for the poor Prepare and adopt Plan of reduction of GART Tqjikiston and Tajik Railway accounts receivable

Incorporation of Tajik Railway and GART Tojikiston considering 100\% state-owned block of stock (in accordance with recommendations and proposals of on-going EBRD project and on-going EBRD survey)

Separate airports services out of State Airlines Company "Tojikiston" structure and transform them into joint stock companies (in accordance with recommendations and proposals of on-going EBRD project and on-going EBRD survey)

Develop Plan of denationalization of automotive-transport and road-construction enterprises and organizations of the sector (first half-year of 2003) and implement this plan (by the end of 2003)

Rehabilitate Dushanbe-Kurgan Tyube-Kulyob road (Phase L USD 9.5 mill.)

Replacement of air-navigation equipment of main airports of the country (Dushanbe and Khuj and) by the end of 2003

$1=$ high, 2 = low, 3 = none; $\mathrm{A}=$ no financing, $\mathrm{B}=$ other (lack of institutional capacity, timing, etc.

(C) International Monetary Fund. Not for Redistribution 


\section{TELECOMMUNICATIONS, TV AND RADIO}

Develop proposals on management system improvement and creation of conditions for the development of communication services market

Preparatory activities towards Tajiktelecom privatization (scheduled for 2004)

Develop and adopt a plan on reduction of communication enterprises accounts receivables

Implementation of EBRD project in part of infrastructure rehabilitation and modernization

Bring sector regulatory framework in line with adopted law "On electric communication"

Amend legislation governing TV and radio broad-casting to ensure competition among programs

Develop sector policy program directed at sector liberalization and promotion of competitive environment for various TV and radio channels, especially at

FM diapason, including private ones

Within the program "Mayji Somon - 2005" introduction and modernization of TV and radio broadcasting stations in the districts of Sugd and Khatlon

Oblasts, and Rasht valley

Develop proposals on targeted assistance to poor with regard to review of communication services tariff structure

Develop programs of rehabilitation of powerful radio broadcasting transmitters using new technologies, transferring to pulse operation, and expanding national digital satellite TV network

Develop the concept of rehabilitation of wire broadcasting system and development of republican radio broadcasting through combined ways using satellite ground receiving stations

Identify Republican network of data transfer (RNDT)

Elaborate strategy of RNDT establishment and development based on fiber-optic technology and determine stages and financing sources

Introduce programs based on INFOCON of distant learning of economic and technical branches of science, as well as courses of upgrading of specialists' information-communication technologies skills

\section{WATER SUPPLY}

Draft and adopt Laws on drinking water and drinking water supply

Develop water saving national program and an action plan for its implementation

Develop mechanism of introduction of strict control over usage of water

Develop and submit proposals on water tariff structure review

Develop proposals on targeted assistance to poor with regard to review of water tariff structure

Develop and adopt plan on rehabilitation, repair, and modernization of key water supply facilities

Develop action plan to reduce sector enterprises and organizations accounts receivable and to avoid accrual of new arrears

Increase the rate of water fees collection up to $100 \%$

Incorporating of autonomous enterprises in the sector into Joint Stock Companies and proposals of development after privatization

Rehabilitate Dushanbe water supply

Implement water supply projects of Khujand-town and Bobojon Gafurov (Khujand district)

Implement water supply projects of Dangara-town and Dangara district

Improve rural water supply: Yavan, Vakhsh, Obi-Kuyuk, and Kumsangir

$\mathbf{1}$ = high, $\mathbf{2}$ = low, $\mathbf{3}$ = none; $\mathbf{A}=$ no financing, $\mathbf{B}=$ other (lack of institutional capacity, timing, etc.

(C)International Monetary Fund. Not for Redistribution 
ATTACHMENT 1

\begin{tabular}{|c|c|c|c|c|c|}
\hline \multirow[t]{2}{*}{ MEASURES } & \multicolumn{3}{|c|}{$\begin{array}{c}\text { Implement } \\
\text { Level }\end{array}$} & \multicolumn{2}{|c|}{ Basis } \\
\hline & 1 & 2 & 3 & A & B \\
\hline \multicolumn{6}{|l|}{ ENVIRONMENT } \\
\hline Prepare and approve National Strategy and Action Plan on Conserving Biodiversity & $\mathbf{X}$ & & & & \\
\hline Environmental recovery of Gissar valley: assess industrial and agricultural facilities and provide for environment protection equipment and inventory & & & $\mathbf{X}$ & $\mathbf{X}$ & \\
\hline Conduct number of seminars on ecological issues for the workers of industrial enterprises and Dehkan farms as well as for local executive power bodies & & & $\mathbf{X}$ & $\mathbf{X}$ & $\mathbf{X}$ \\
\hline Rehabilitate and establish infrastructure of ecological monitoring of environment & & & $\mathbf{X}$ & $\mathbf{X}$ & \\
\hline Establish enterprises on production of modem domestic equipment for ecological monitoring and of environment protection agencies & & & $\mathbf{X}$ & $\mathbf{X}$ & \\
\hline Evaluate on-going activities and implement adoption by the Government regulations on environment protection & & & $\mathbf{X}$ & & $\mathbf{X}$ \\
\hline Prepare and approve National Environmental Action Plan & $\mathbf{X}$ & & & & \\
\hline Identify financing source Implementation of pilot projects within Country Program to Combat Desertification in Tajikistan & & $\mathbf{X}$ & & & \\
\hline Develop and approve First National Communication on climate change (improve cooperation with region countries on climate changes issues) & $\mathbf{X}$ & & & & \\
\hline Conduct intrastate procedures on approval of National Program on stopping use of ozone-depleting substances & $\mathbf{X}$ & & & & \\
\hline Elaborate projects on development of non-traditional energy sources for rural energy supply based on solar electric power, wind energy, and bio-gas & & $\mathbf{X}$ & & $\mathbf{X}$ & \\
\hline \multicolumn{6}{|l|}{ TOURISM } \\
\hline Create national tourism development program & $\mathbf{X}$ & & & & \\
\hline Simplify visa formalities, develop special tourist visas & $\mathbf{X}$ & & & & \\
\hline Consider the issues of free access to GBAO territory for the purposes of visiting tourist objects & $\mathbf{X}$ & & & & \\
\hline $\begin{array}{l}\text { Within the framework of Berlin International Fair (March 2003) in order to support initiative of the President of RT '2003: Year of Fresh Water' to carry out } \\
\text { action on issuing visa to foreign tourists on no-fee basis }\end{array}$ & $\mathbf{X}$ & & & & \\
\hline
\end{tabular}

1 = high, 2 = low, 3 = none; $\mathrm{A}=$ no financing, $\mathrm{B}=$ other (lack of institutional capacity, timing, etc. 


\section{MATRIX OF LEGAL BASE FOR PRSP IMPLEMENTATION}

(Reporting period June 2002 - December 2003) 
MATRIX OF LEGAL BASE FOR PRSP IMPLEMENTATION

DURING FIRST YEAR

(Reporting period June 2002 - December 2003)

\begin{tabular}{|c|c|c|c|c|c|c|}
\hline & \multirow[t]{2}{*}{ Legislation and other legal acts } & \multicolumn{2}{|c|}{2002} & \multicolumn{2}{|c|}{2003} & \multirow[t]{2}{*}{ Link to PRSP } \\
\hline & & Adopted & Amended & Adopted & Amended & \\
\hline \multicolumn{7}{|c|}{ ECONOMIC MANAGEMENT } \\
\hline 1. & Law on Annual State Budget (2003) & Dec 2 & & & & $\begin{array}{l}\text { State budget allocation to social sectors at } 43 \%, 12 \text { mill } \\
\text { Sm for cash compensations, and increase of salaries, } \\
\text { pensions, and allowances. }\end{array}$ \\
\hline 2. & Program of Economic Development to 2015 & & & March 1 & & Social and economic development policies to 2015 \\
\hline 3 & Law on Annual State Budget (2004) & & & Dec 16 & & $\begin{array}{l}\text { Social sector share of expenditures comprises about } \\
45 \% \text { and } 20 \text { mill. Sm for cash compensations. }\end{array}$ \\
\hline 4 & Law on Public Finance of RT & Dec 2 & & & & $\begin{array}{l}\text { Principles of modern budget management (MTEF, } \\
\text { accountability, transparency) }\end{array}$ \\
\hline 5 & Law on Guaranteeing of Deposits of Individuals & & & Augl & & Banking, deposits protection policy \\
\hline 6. & Law on National Bank & Dec 2 & & & & Compliance with IAS \\
\hline 7. & $\begin{array}{l}\text { Law "On amnesty of the citizens of the RT related to the } \\
\text { legalization of cash resources" }\end{array}$ & & & May 10 & & $\begin{array}{l}\text { Legal and organizational aspects of one-time action on } \\
\text { legal repatriation by citizens of their money. Attract }\end{array}$ \\
\hline 8. & $\begin{array}{l}\text { Establishment of Timeline for Money Legalization by } \\
\text { Presidential Decree }\end{array}$ & & & Mar 12 & Junl & investments into real economy. \\
\hline 9. & External Debt Reduction Strategy & & & M4 & & $\begin{array}{l}\text { Reduce sovereign debt stock, and reduce and postpone } \\
\text { debt service payments from the budget. }\end{array}$ \\
\hline 10. & Law of RT on Financial Leasing & & & Apr 22 & & $\begin{array}{l}\text { Legal and organizational background for financial rent } \\
\text { in market environment. Increase investment activities. }\end{array}$ \\
\hline \multicolumn{7}{|c|}{ REFORM OF GOVERNANCE } \\
\hline 11. & Law on State Financial Control in RT & Dec 2 & & & & $\begin{array}{l}\text { Accountability, transparency, and effectiveness in } \\
\text { public expenditure management. }\end{array}$ \\
\hline 12. & Law on Civil Service & & May 3 & & & $\begin{array}{l}\text { Proper classification and staffing levels for public } \\
\text { agencies. }\end{array}$ \\
\hline 13. & $\begin{array}{l}\text { President Decree On Establishment of the Institute of } \\
\text { Upgrading of Qualification of Civil Servants of RT }\end{array}$ & Oct9 & & & & Training of skilled and qualified specialists \\
\hline 14. & $\begin{array}{l}\text { President Decree on State Posts Register and Qualification } \\
\text { Requirements (No. 946) }\end{array}$ & Dec 2 & & & & Civil servant qualification requirements are introduced \\
\hline \multicolumn{7}{|c|}{ SOCIAL PROTECTION } \\
\hline 15. & $\begin{array}{l}\text { President Decree "On increasing minimum wages, salaries } \\
\text { of workers of budget-funded institutions and organizations, }\end{array}$ & Oct25 & & & & $\begin{array}{l}\text { Increasing living wages by } 20 \% \text { (without considering } \\
\text { the growth of minimum wages) }\end{array}$ \\
\hline
\end{tabular}


ATTACHMENT 2

\begin{tabular}{|c|c|c|c|c|c|c|}
\hline & \multirow[t]{2}{*}{ Legislation and other legal acts } & \multicolumn{2}{|c|}{2002} & \multicolumn{2}{|c|}{2003} & \multirow[t]{2}{*}{ Link to PRSP } \\
\hline & & Adopted & Amended & Adopted & Amended & \\
\hline & and pensions and scholarships" & & & & & \\
\hline 16. & $\begin{array}{l}\text { President Decree "About additional measures on } \\
\text { improvement of material welfare of veterans and invalids of } \\
\text { the Great Patriotic War and widows of those who served in } \\
\text { the military and died" No. } 879\end{array}$ & Aug31 & & & & $\begin{array}{l}\text { Increase pensions by } 20 \mathrm{Sm} \text { and compensation for widows } \\
\text { by } 10 \mathrm{Sm}\end{array}$ \\
\hline 17 & $\begin{array}{l}\text { President Decree "About establishment of minimum and } \\
\text { maximum size of old-age pension" No. } 824\end{array}$ & May 6 & & & & \begin{tabular}{|l} 
Minimum old-age pension is set at 5 Sm. and \\
maximum $70 \mathrm{Sm}$.
\end{tabular} \\
\hline 18. & $\begin{array}{l}\text { President Decree "About measures on enhancement of } \\
\text { population social protection and minimum wage increase" } \\
\text { No. } 1173\end{array}$ & Nov4 & & & & Wages raised by $25 \%$. \\
\hline \multicolumn{7}{|c|}{ HEALTH } \\
\hline 19. & Law on Private Medical Practice & Dec 2 & & & & Develop private medical activities \\
\hline 20. & Law on Reproductive Health and Reproductive Rights & Dec 2 & & & & $\begin{array}{l}\text { Ensures family and maternity protection; family } \\
\text { planning }\end{array}$ \\
\hline 21. & Law on Iodized Salt & Dec 2 & & & & Actions and requirements for iodized salt \\
\hline 22. & Law on Psychiatric Care & Dec 2 & & & & $\begin{array}{l}\text { Protection of rights and legal interests of people with } \\
\text { mental disorders }\end{array}$ \\
\hline 23. & Concept of Health Care System Reforms & Mar & & & & $\begin{array}{l}\text { Identifies stages and forms of Health Care System } \\
\text { reforms }\end{array}$ \\
\hline 24. & $\begin{array}{l}\text { Strategy of population health protection for the period to } \\
2010\end{array}$ & Nov & & & & Improve health indicators \\
\hline 25. & Program of tuberculosis control in $2003-2010$ & & & & & Prevent spread of tuberculosis \\
\hline 26 & Strategic plan of prevention of threat of HTV7AIDS spread & & & & & Prevent threat of HTV/AIDS spreading \\
\hline 27. & Law on Medicines and Pharmaceutical Activities & & & - & & Licensing and import/export procedures \\
\hline 28. & Law on Provision Population with Sanitary and Epidemic Security & & & Dec 8 & & Improve health indicators \\
\hline \multicolumn{7}{|c|}{ EDUCATION } \\
\hline 29. & Law on Primary Vocational Training & & & Apr 22 & & $\begin{array}{l}\text { Development of vocational education in market } \\
\text { economy }\end{array}$ \\
\hline 30. & Law on Higher and Postgraduate Vocational Education & & & Dec 8 & & \\
\hline 31. & $\begin{array}{l}\text { President Decree "About improving teaching and learning } \\
\text { of Russian and English in the Republic of Tajikistan)) }\end{array}$ & & & Apr4 & & $\begin{array}{l}\text { Develop international relations and accelerate higher } \\
\text { technical learning. }\end{array}$ \\
\hline 32. & $\begin{array}{l}\text { President Decree "About establishment of Coordination } \\
\text { council of higher, secondary and primary vocational schools } \\
\text { of RT" }\end{array}$ & Jul 15 & & & & $\begin{array}{l}\text { Coordination of effective activities of higher, } \\
\text { secondary and primary vocational schools regardless } \\
\text { their departmental subordination as well as } \\
\text { establishment of single state control in the branch. }\end{array}$ \\
\hline 33. & $\begin{array}{l}\text { Government Program on Computerization of Primary and } \\
\text { Secondary/High Schools in 2003-2007 }\end{array}$ & & & & & School computerization \\
\hline
\end{tabular}


ATTACHMENT 2

\begin{tabular}{|c|c|c|c|c|c|c|}
\hline & \multirow[t]{2}{*}{ Legislation and other legal acts } & \multicolumn{2}{|c|}{2002} & \multicolumn{2}{|c|}{2003} & \multirow[t]{2}{*}{ Link to PRSP } \\
\hline & & Adopted & Amended & Adopted & Amended & \\
\hline 34. & $\begin{array}{l}\text { Government decision on state educational standard for } \\
\text { primary education }\end{array}$ & Nov & & & & \\
\hline \multicolumn{7}{|c|}{ AGRICULTURE } \\
\hline 35. & Law on Veterinary Medicine & & & Dec 8 & & Principles of development private veterinary services \\
\hline 36. & Law on Dehkan Farms & & & May 10 & & Legal forms of Dehkan Farms creation and activities \\
\hline 37. & $\begin{array}{l}\text { President Decree "About additional measures on ensuring } \\
\text { effective activities of cotton-growing farms and investors in } \\
\text { the course of cotton production, processing and sale" }\end{array}$ & & Sep21 & & & $\begin{array}{l}\text { Prohibits interference in production decisions and } \\
\text { farmer activities }\end{array}$ \\
\hline 38. & $\begin{array}{l}\text { President Decree "About mechanism of adjustment of debts } \\
\text { of agricultural enterprises and organizations, which are } \\
\text { already reorganized or under reorganization" }\end{array}$ & & & Apr 15 & & Mechanism for debt write-offs \\
\hline 39. & Law on Seed Breeding & Dec 2 & & & & \\
\hline 40. & $\begin{array}{l}\text { President Decree "About VAT exemption for raw cotton } \\
\text { supplies and changes of the rate of cotton-fiber sales tax" }\end{array}$ & Sep20 & & & & $\begin{array}{l}\text { Support to cotton-growing farms; increase of cotton } \\
\text { production in the republic }\end{array}$ \\
\hline \multicolumn{7}{|c|}{ PRIVATIZATION } \\
\hline 41. & Law on Securities and Stock Exchange & & & & & \\
\hline 42. & Law on State-owned Enterprises & & & & & \\
\hline 43. & Law on Bankruptcy & & & Dec 8 & & \\
\hline 44. & Strategic plan of state property privatization & & & Dec 8 & & Plan of mid-size and large enterprises privatization \\
\hline \multicolumn{7}{|c|}{ LABOR AND POPULATION } \\
\hline 45. & Law on Employment Promotion & & & Augl & & $\begin{array}{l}\text { Regulates public relations on population employment } \\
\text { and determines grounds for state policy in market } \\
\text { economy. }\end{array}$ \\
\hline 46. & Law on Migration & & May 10 & & & $\begin{array}{l}\text { Labor migration procedures; measures on protection of } \\
\text { labor migrants' rights. }\end{array}$ \\
\hline 47. & 2003-2005 Program of Facilitation of Employment. & & & Mar & & Lower unemployment \\
\hline \multicolumn{7}{|c|}{ DEVELOPMENT OF PRIVATE SECTOR } \\
\hline 48. & $\begin{array}{l}\begin{array}{l}\text { Law on Government Protection and Support of } \\
\text { Entrepreneurship in RT }\end{array} \\
\end{array}$ & May 10 & & & & Develop entrepreneurship. \\
\hline 49. & Law on State Registration of Legal Entities & & & May 7 & & $\begin{array}{l}\text { Single state registration of legal entities in the justice } \\
\text { ministry offices. }\end{array}$ \\
\hline 50. & $\begin{array}{l}\text { Law "About introduction of changes and amendments into } \\
\text { the Law of RT "On foreign economic activities" }\end{array}$ & & & & & $\begin{array}{l}\text { Eliminates additional registration of Foreign Economic } \\
\text { Activities Subjects at MOET. }\end{array}$ \\
\hline 51. & $\begin{array}{l}\text { Government program of entrepreneurship support for 2002- } \\
2005\end{array}$ & Octl & & & & Develop entrepreneurship \\
\hline
\end{tabular}


ATTACHMENT 2

\begin{tabular}{|c|c|c|c|c|c|c|}
\hline & \multirow[t]{2}{*}{ Legislation and other legal acts } & \multicolumn{2}{|c|}{2002} & \multicolumn{2}{|c|}{2003} & \multirow[t]{2}{*}{ Link to PRSP } \\
\hline & & Adopted & Amended & Adopted & Amended & \\
\hline \multicolumn{7}{|c|}{ INFRASTRUCTURE } \\
\hline 52. & Law on Electrical Communication & May 10 & & & & Functions of sector in market economy \\
\hline 53. & Law on Electronic Document & May 10 & & & & Legal grounds for electronic document applicatioa \\
\hline 54. & Law on Information & May 10 & & & & \\
\hline 55. & Law on Postal Communication & May 10 & & Aug 1 & & Functions of sector in market economy \\
\hline 56. & Law on Energy Saving/preservation & May 10 & & & & State energy policy in market economy \\
\hline 57. & Law on Communication by Courier & Dec 2 & & & & Functions of sector in market economy \\
\hline \multicolumn{7}{|c|}{ ENVIRONMENTAL PROTECTION, TOURISM } \\
\hline 58. & Law on Residential Waste & May 10 & & & & Procedures of proper handling of waste \\
\hline 59. & Law on Nature Protection & May 10 & & & & New international practices are introduced. \\
\hline 60. & Law on Tourism & & & & & New forms of tourism activity development \\
\hline 63. & \begin{tabular}{|llll}
$\begin{array}{l}\text { Government Decision "About licensing of tourism } \\
\text { activities" }\end{array}$ & \\
\end{tabular} & Oct 1 & & & & \\
\hline 64. & Country Ozone-Depletion Program & Dec & & & & Climate change hampering measures \\
\hline 65. & $\begin{array}{l}\text { National Strategy and Action Plan on Preservation and } \\
\text { Rational Use of Biodiversity }\end{array}$ & & & Sep & & Preserving habitat, biodiversity \\
\hline 66. & $\begin{array}{l}\text { National Program on Combating Desertification in } \\
\text { Tajikistan }\end{array}$ & & & Sep & & Soil erosion protection, \\
\hline
\end{tabular}




\section{SURVEYS USED IN THE PROGRESS REPORT}




\section{Living Standards Survey and Poverty Assessment Update, WB (TLSS 2003)}

From the TLSS 2003, only the preliminary results and comparisons in relation to TLSS 1999 are available for use in the Progress Report. The TLSS 2003 uses methodology of applying quintiles on changes in expenditures in the living standards of 4,160 households from all regions. The TLSS collected data on expenditures and property, as well as demographic characteristic, migrations, living conditions, education, health, agriculture, and employment. We look forward to the detailed analyses from this assessment for our poverty monitoring and evaluation work.

The share of population classified under poverty level has declined during the reporting period. We base this conclusion on data that spans a period (1999-2003), which is longer than the reporting period. The fact that the real economic growth has been strong since 2000 supports this assertion. The real per capita income rose during this period.

The lack of identification of a standard consumer basket makes quantitative analysis difficult. According to the preliminary results of the WB TLSS, the poverty level fell moderately since 1999 . With purchasing power parity (PPP) indicator of $\$ 2.15 /$ day, the share of the population below poverty baseline fell from $65 \%$ in 1999 to $57 \%$ in 2003 . If we choose the average of the OSCE and the World Bank PPP calculations, the share of the population below poverty level in 2003 would be $61 \%$ instead of $57 \%$.

The poverty profile has a regional character. Table 1. indicates that many regions gained ground in reducing poverty, while others may have not been as successful. In particular, data on Khatlon region, whose population grew by $9 \%$ since 1999 , indicates sustained poverty levels. There are indications that despite total income gains, the income inequality may be growing among the population (increase in the share of the poorest quintile in Khatlon).

Table 1. Population living below PPP \$2.15/day by region $(1999,2003)$

\begin{tabular}{|l|c|c|c|c|}
\hline Region & $\begin{array}{c}\text { Population } \\
\text { (thou) 1999 }\end{array}$ & $\begin{array}{c}\text { Below } \\
\text { poverty line } \\
1999 \\
\%\end{array}$ & $\begin{array}{c}\text { Population } \\
\text { (thou) 2003 }\end{array}$ & $\begin{array}{c}\text { Below } \\
\text { poverty line } \\
\mathbf{2 0 0 3} \\
\%\end{array}$ \\
\hline & & & & \\
\hline Dushanbe & $\mathbf{5 6 0}$ & $\mathbf{3 9}$ & 620 & 31 \\
\hline GBAO & $\mathbf{2 1 3}$ & $\mathbf{8 1}$ & 214 & $\mathbf{5 4}$ \\
\hline Sugd & $\mathbf{1 , 8 7 0}$ & $\mathbf{6 6}$ & 1,989 & 60 \\
\hline Khatlon & $\mathbf{2 , 1 4 5}$ & $\mathbf{1 1}$ & 2,343 & 79 \\
\hline RSS & $\mathbf{1 , 3 4 0}$ & $\mathbf{5 4}$ & 1,466 & 37 \\
\hline & & & & \\
\hline TOTAL & $\mathbf{6 , 1 2 8}$ & $\mathbf{6 5}$ & $\mathbf{6 , 6 3 2}$ & $\mathbf{5 7}$ \\
\hline
\end{tabular}

Source: PRSPMD staff and WE TLSS 1999 and 2003.

Related to the difference the choice of PPP makes, a study by the SSC with another level of PPP indicated that poverty level fell from $83 \%$ to $68 \%$ of the population between 
1999 and 2003. For this assessment, the SSC applied the poverty baseline of 20,000 Tajik Rubles in 1999, equivalent to $49.6 \mathrm{Sm}$. in 2003 adjusted by consumer price index. Even though the results on poverty reduction vary in degrees, the positive trend is undeniable. There has been a secular increase in the level of living conditions of the total population during the reporting period.

Table 2. Distribution of quintiles by regions (TLSS 2003)

\begin{tabular}{|l|c|c|c|c|c|}
\hline \hline \multicolumn{1}{|c|}{ Region } & \multicolumn{5}{|c|}{ Quintiles (\% of population) } \\
\hline & $\mathbf{1}^{*}$ & $\mathbf{2}$ & $\mathbf{3}$ & $\mathbf{4}$ & $\mathbf{5}$ \\
\hline Dushanbe & $\mathbf{1 1}$ & $\mathbf{1 2}$ & $\mathbf{1 9}$ & 27 & 31 \\
\hline GBAO & 20 & 23 & $\mathbf{2 4}$ & $\mathbf{2 2}$ & $\mathbf{1 2}$ \\
\hline Sg2d & $\mathbf{2 2}$ & $\mathbf{2 4}$ & $\mathbf{2 4}$ & $\mathbf{1 7}$ & $\mathbf{1 2}$ \\
\hline Khatlon & 38 & 27 & $\mathbf{1 7}$ & $\mathbf{1 1}$ & $\mathbf{7}$ \\
\hline RSS & 12 & 15 & $\mathbf{2 1}$ & 28 & 25 \\
\hline
\end{tabular}

Source: WE TLSS 2003.

* Poorest. $20 \%$ of the population.

According to TLSS 2003, preliminary data indicates that in the distribution of consumption, bottom quinti1e proportion increased to $24 \%$ (2003) from $22 \%$ (1999). Bottom quintile spends $71 \%$ of expenditures on food. The rural population has more people in the bottom quintiles (1-3) than the urban population.

Table 3. Distribution of quintiles by urban/rural (TLSS 2003)

\begin{tabular}{|l|c|c|c|c|c|l|}
\hline \hline Region & \multicolumn{5}{|c|}{ Quintiles (\% of population) } & \\
\hline & $1^{*}$ & 2 & 3 & 4 & 5 & Total \\
\hline Urban & 20 & 19 & 19 & 22 & 20 & 100 \\
\hline Rural & 26 & 23 & 21 & 18 & 13 & 100 \\
\hline TOTAL & 24 & $2 J$ & 11 & 18 & 13 & 100 \\
\hline
\end{tabular}

Source: WE TLSS 2003.

* Poorest $20 \%$ of the population. 


\section{National Nutrition and Water and Sanitation Survey, (2003)}

NNWSS has been an annual survey based on the work of 12-15 organizations. There were 4 previous surveys in 1999-2002. NNWSS has been coordinated by NGOs Action Against Hunger and Mercy Corps and financed by NGO ECHO.' The NNWSS 2003 study includes analyses of the nutritional status of children aged 6-59 months as well as assessment of the relationship between water quality, quantity and hygiene practices as causal factors that may contribute to malnutrition. The NNWSS was conducted in all regions of Tajikistan between October 6, 2003 and November 6, 2003. The NNWSS 2001 was conducted during the same season, which makes possible data comparisons with NNWSS 2003. The total sample size was 4,653 .

The NNWSS 2003 provides child morbidity information based on questionnaires. The caregivers were asked if the child had been ill in the previous month and the suspected illness recorded. Data interpretations should be made with the proviso that there were not any methods to cross check this information. The frequency of disease among children of 6-59 month of age is highest in the two Khatlon districts (Kulyob and Kurgan Tyube).

Table 4. Child morbidity (2003)

\begin{tabular}{|l|c|c|}
\hline \multicolumn{1}{|c|}{ Region } & $\begin{array}{c}\text { One episode of } \\
\text { illness } \\
\text { \% }\end{array}$ & $\begin{array}{c}\text { No Illness } \\
\text { \% }\end{array}$ \\
\hline GBAO & 33.4 & 66.6 \\
\hline Sugd & 33.6 & 66.4 \\
\hline RRS & 32.5 & 67.5 \\
\hline Kurgan Tvube & $\mathbf{4 2 . 4}$ & 57.6 \\
\hline Kulob & $\mathbf{5 8 . 2}$ & $\mathbf{4 1 . 8}$ \\
\hline & & $\mathbf{6 0 . 0}$ \\
\hline Total & $\mathbf{4 0 . 0}$ & \\
\hline
\end{tabular}

Source: NNWSS 2003

Table 5. compares the child morbidity findings from 2003 and 2001.

Table 5. Reported children diseases and frequency $(2003,2001)$

\begin{tabular}{|l|c|c|}
\hline \multicolumn{1}{|c|}{ Disease } & $\begin{array}{c}2003 \\
(\%)\end{array}$ & $\begin{array}{c}2001 \\
(\%)\end{array}$ \\
\hline Fever & 4.1 & 34.1 \\
\hline Diarrhea & 18.1 & 31.1 \\
\hline Cough & 11.4 & 28.8 \\
\hline & & \\
\hline Total & 40.0 & 61.6 \\
\hline
\end{tabular}

Source: NNWSS 2003

The NNWSS compiled regional comparative data on acute malnutrition (wasting) and

\footnotetext{
${ }^{1}$ European Commission Humanitarian Aid Office

${ }^{2} \mathrm{GBAO}$ is excluded from the comparison.
} 
chronic malnutrition (stunting) between 2003 and 2001. ${ }^{3}$ Acute malnutrition refers to children with low weight for height and indicates sudden decline in food intake over recent months. Table 6. shows that Khatlon (Kulyob and Kurgan Tyube districts) has the highest rates of acute malnutrition.

Table 6. Acute malnutrition by region. $(2003, \mathrm{~b}$

\begin{tabular}{|l|c|c|c|c|c|}
\hline \multicolumn{1}{|c|}{ Region } & $\begin{array}{c}\text { Number of } \\
\text { children } \\
6-59 \text { months }\end{array}$ & \multicolumn{2}{|c|}{$\begin{array}{c}\text { Global Acute } \\
\text { Malnutrition } \\
<-2 \text { Z-scores* }\end{array}$} & \multicolumn{2}{c|}{$\begin{array}{c}\text { Severe Acute } \\
\text { Malnutrition } \\
<-3 \text { Z-scores }\end{array}$} \\
\hline & & $\begin{array}{c}\mathbf{2 0 0 3} \\
(\%)\end{array}$ & $\begin{array}{c}\mathbf{2 0 0 1} \\
(\%)\end{array}$ & $\begin{array}{c}\mathbf{2 0 0 3} \\
(\%)\end{array}$ & $\begin{array}{c}\mathbf{2 0 0 1} \\
(\%)\end{array}$ \\
\hline GBAO* & 938 & $\mathbf{3 . 7}$ & $\mathbf{n} / \mathbf{a}$ & 0.1 & $\mathbf{n} / \mathbf{a}$ \\
\hline Sugd & 919 & $\mathbf{3 . 3}$ & 15.4 & $\mathbf{0 . 4}$ & $\mathbf{3 . 4}$ \\
\hline RRS & 942 & $\mathbf{4 . 0}$ & 16.1 & $\mathbf{0 . 4}$ & $\mathbf{4 . 0}$ \\
\hline Kurgan Tyube & 930 & $\mathbf{5 . 4}$ & 20.0 & 0.9 & $\mathbf{5 . 6}$ \\
\hline Kulyob & 925 & $\mathbf{7 . 1}$ & $\mathbf{1 7 . 6}$ & $\mathbf{1 . 4}$ & $\mathbf{3 . 9}$ \\
\hline & & & & & \\
\hline TOTAL & $\mathbf{4 , 6 5 4}$ & $\mathbf{4 . 7}$ & $\mathbf{1 7 . 3}$ & $\mathbf{0 . 6 4}$ & $\mathbf{4 . 2}$ \\
\hline
\end{tabular}

Source.. NNWSS 2003, NNWSS 2001.

*Z-scores refer to number of standard deviations from the median of the reference population.

**GBAO region was not included in the NNWSS 2001.

Chronic malnutrition refers to children with low height in relation to their age and indicates cumulative and sustained low food intake. Table 7. shows that Kurgan Tyube has the highest and RRS the lowest rates of chronic malnutrition.

Table 7. Chronic malnutrition by re2ion. (2003 and 2001)

\begin{tabular}{|l|c|c|c|}
\hline \multicolumn{1}{|c|}{ Region } & $\begin{array}{c}\text { Number of } \\
\text { children } \\
6-59 \text { months }\end{array}$ & $\begin{array}{c}\text { Global Chronic } \\
\text { Malnutrition } \\
<-2 Z-S c o r e s *\end{array}$ & $\begin{array}{c}\text { Global } \\
\text { Chronic } \\
\text { Malnutrition } \\
<-2 Z-S c o r e s\end{array}$ \\
\hline & 938 & $\mathbf{2 0 0 3}$ & $\begin{array}{c}\mathbf{2 0 0 1} \\
\mathbf{\%}\end{array}$ \\
\hline GBAO** & 919 & 32.5 & $\boldsymbol{n} / \boldsymbol{a}$ \\
\hline Sugd & 942 & 36.6 & 43.8 \\
\hline RRS & 930 & 41.2 & 32.8 \\
\hline Kurgan Tyube & 925 & 39.9 & 36.9 \\
\hline Kulyob & & & 34.9 \\
\hline & $\mathbf{4 , 6 5 4}$ & $\mathbf{3 6 . 2}$ & $\mathbf{3 7 . 1 *}$ \\
\hline TOTAL & & &
\end{tabular}

Source.. NNWSS 2003, NNWSS 2001.

* Z-scores refer to number of standard deviations from the median of the reference population.

${ }^{* *} G B A O$ region was not included in the 2001 National Nutrition Survey.

'GBAO region was not included in the NNWSS 2001. 
Acute malnutrition (wasting) in Tajikistan has steadily decreased since 1999 and sharply declined since 2001, when a record high of $17.3 \%$ was recorded. Currently, just less than 5\% of children aged 6-59 months in Tajikistan suffer from acute malnutrition. The rates of chronic malnutrition (stunting) continue to be of great concern. Over $30 \%$ of children in Tajikistan suffer from chronic malnutrition. Little or no change can be seen since the NNWSS 1999. In Khatlon, the situation has even worsened. Chronic malnutrition is related to a long-term deficit of macro and micronutrients and therefore suggests two scenarios, a precarious food security situation and/or poor feeding practices still persistent in Tajikistan. The causal factors associated with malnutrition were explored, and illness, especially diarrhea, was found to have significant impact on malnutrition. ${ }^{4}$

The NNWSS 2003 finds that, while acute malnutrition rates have decreased in Tajikistan because of improved breastfeeding practices, a decline in morbidity and greater food security, many children remain at risk. The 'at risk population', which is defined as being in the Z-score range of 1.5 to 2.0 , is calculated to be around $6 \%$ in Tajikistan. The dramatic manifestation of acute malnutrition in 2001, which was a drought year, would be repeated if any such shock could once again occur. The current 'at risk population' would be pushed into a acute malnourished status. It is estimated that malnutrition rates may increase up to 3.2 times their current level. GBAO and Kulyob have the greatest number of 'at risk population' and therefore are the regions most vulnerable to shocks.

\section{Monitoring Survey, SSC and ADB (2002)}

The SSC conducted a monitoring survey of poverty reduction, which the ADB funded. The purpose of the survey was to develop a mechanism to monitor poverty. A property index was adopted as an indicator of the general economic status of households. The survey did not identify a poverty baseline. The survey was based on 6,000 households from five regions.

According to the property index only $5.1 \%$ of urban population belongs to the two poorest groups, while $59.8 \%$ belongs to the category of the richest. On the other hand, $52.9 \%$ of the population in the rural areas belongs to the two poorest groups and only $5.4 \%$ belong to the richest.

Table 8. Distribution of quintiles (urban/rural) (2002)

\begin{tabular}{|l|l|l|l|l|l|l|}
\hline Region & \multicolumn{5}{|c|}{ Quintiles (\% of population) } & \\
\hline & $\mathbf{1}^{*}$ & $\mathbf{2}$ & $\mathbf{3}$ & $\mathbf{4}$ & $\mathbf{5}$ & Total \\
\hline Urban & $\mathbf{0 . 6}$ & $\mathbf{4 . 5}$ & 12.3 & 22.9 & $\mathbf{5 9 . 8}$ & $\mathbf{1 0 0 . 0}$ \\
\hline Rural & 27.1 & 25.8 & 22.8 & 18.9 & $\mathbf{5 . 4}$ & $\mathbf{1 0 0 . 0}$ \\
\hline
\end{tabular}

Source: ADB and SSC survey. 2002 (PRMS data, property indicator) ${ }^{5}$

* Poorest $20 \%$ of the population.

\footnotetext{
${ }^{4}$ NNWSS 2003

${ }^{5}$ PRMS - Poverty Reduction Monitoring Survey
} 
In regional comparisons, Dushanbe has the highest share of the population in the richest quintile and RRS and Khatlon have the highest shares of the populations in the poorest quintiles.

Table 9. Distribution of Quintiles by regions (2002)

\begin{tabular}{|l|c|c|c|c|c|c|}
\hline \hline Region & \multicolumn{5}{|c|}{ Quintiles (\% of population) } & \\
\hline & $\mathbf{1 .}$ & $\mathbf{2}$ & $\mathbf{3}$ & $\mathbf{4}$ & $\mathbf{5}$ & Total \\
\hline Dushanbe & 0.3 & 2.1 & 5.2 & 14.2 & 78.2 & 100.0 \\
\hline GBAO & - & - & 26.8 & 31.5 & 41.6 & 100.0 \\
\hline Sugd & 15.2 & 23.5 & 23.7 & 21.1 & 16.5 & 100.0 \\
\hline Khatlon & 28.4 & 21.8 & 20.2 & 18.0 & 11.6 & 100.0 \\
\hline RSS & 24.8 & 22.6 & 19.8 & 22.4 & 10.4 & 100.0 \\
\hline
\end{tabular}

Source: ADB and SSC survey. 2002 (PRMS data, property indicator)

* Poorest $20 \%$ of the population.

In total, $53.3 \%$ of the population evaluated their living standards as poor, while only $6.2 \%$ of the population considered themselves rich. The ADB had conducted a poverty survey in 1999. Because the methodologies of the two surveys were not directly comparable, conclusions with respect to quantifying poverty changes are not possible.

\section{Survey of the National Social Investment Fund of Tajikistan, (2003)}

The NSIFT survey was conducted at the level of jamoat and mahalla councils in the regions. The regional surveys identify poverty in five categories: extremely poor, very poor, poor, average level of poverty, above the average level poverty.

Table 10. Share of DoDulation bv novertv cate2ories bv re2ions

\begin{tabular}{|l|c|c|c|c|c|c|c|}
\hline \multicolumn{1}{|c|}{ Region } & $\begin{array}{c}\text { Number } \\
\text { of } \\
\text { Jamoats }\end{array}$ & $\begin{array}{c}\text { Extremely } \\
\text { poor } \\
\text { \% }\end{array}$ & $\begin{array}{c}\text { Very } \\
\text { poor } \\
\%\end{array}$ & $\begin{array}{c}\text { Poor } \\
\text { \% }\end{array}$ & $\begin{array}{c}\text { Average } \\
\text { level of } \\
\text { poverty } \\
\text { \%o }\end{array}$ & $\begin{array}{c}\text { Above } \\
\text { average } \\
\text { level of } \\
\text { poverty } \\
\text { \%o }\end{array}$ & $\begin{array}{c}\text { Total } \\
\%\end{array}$ \\
\hline $\begin{array}{l}\text { RRS (except } \\
\text { Rasht Valley) }\end{array}$ & $\mathbf{2 4}$ & $\mathbf{7 0 . 8}$ & $\mathbf{8 . 3}$ & $\mathbf{2 0 . 8}$ & $\mathbf{0 . 0}$ & $\mathbf{0 . 0}$ & 100.0 \\
\hline Rasht Valley & 22 & $\mathbf{0 . 0}$ & 4.5 & $\mathbf{8 6 . 4}$ & $\mathbf{9 . 1}$ & $\mathbf{0 . 0}$ & 100.0 \\
\hline Kurgan-Tyube & $\mathbf{5 8}$ & $\mathbf{3 6 . 2}$ & 34.5 & $\mathbf{2 9 . 3}$ & $\mathbf{0 . 0}$ & $\mathbf{0 . 0}$ & 100.0 \\
\hline Kulyob & $\mathbf{3 7}$ & $\mathbf{3 7 . 8}$ & 46.0 & $\mathbf{1 6 . 2}$ & $\mathbf{0 . 0}$ & $\mathbf{0 . 0}$ & 100.0 \\
\hline GBAO & $\mathbf{3 9}$ & $\mathbf{1 5 . 4}$ & $\mathbf{2 8 . 2}$ & $\mathbf{5 6 . 4}$ & $\mathbf{0 . 0}$ & $\mathbf{0 . 0}$ & 100.0 \\
\hline Sugd & $\mathbf{7 2}$ & $\mathbf{4 0 . 3}$ & $\mathbf{4 0 . 3}$ & $\mathbf{1 9 . 4}$ & $\mathbf{0 . 0}$ & $\mathbf{0 . 0}$ & 100.0 \\
\hline Dushanbe City* & $\mathbf{2 0}$ & $\mathbf{5}$ & 95 & $\mathbf{0 . 0}$ & $\mathbf{0 . 0}$ & $\mathbf{0 . 0}$ & 100.0 \\
\hline & & & & & & & \\
\hline Total & 272 & 33.3 & 36.6 & 29.3 & $\mathbf{0 . 7}$ & $\mathbf{0 . 1}$ & 100.0 \\
\hline
\end{tabular}

Source: Survey of the National Social Investment Fund of Tajikistan by regions,

2003. * Selected districts.

Results of the survey show that of the 272 jamoat and mahalla councils, the majority falls under the category of "very poor" (36.6\%), followed by "extremely poor" (33.3\%), "poor" (29.3\%) and "average level of poverty $(0.7 \%)$. 
The survey revealed priority issues in reducing poverty. High unemployment rate overlays and deepens the overall poverty conditions. The most important problems included lack of fresh water, roads in disrepair, schools and medical facilities in need of repairs or reconstruction. Access to electricity and telecommunication were also serious problems.

\section{Multi-indicative Cluster Survey, UNICEF (2000)}

MICS covered 3,720 households in five administrative regions. Because the indicators were collected for the first time in the last ten years, we can not draw conclusions on changes during the reporting period.

The survey findings showed that infant mortality rate was 89 per 1000 . The rate among children under 5 years of age was 126 per 1000 . Nationally, only $75 \%$ of children under 5 years of age have their births registered. This rate varies between regions; they are $92 \%$ in Sugd, 62\% in Dushanbe, and 63\% in RRS.

School enrollment rate for children, ages $8-9$ years, was $93 \%$. Only $94 \%$ of children, who start elementary school in first grade reach fifth grade. About $95 \%$ of population over the age of 15 years is literate; the rates for 55-64 years age group was $86 \%$ and for 65 years and over was $66 \%$.

About $20 \%$ of households consume adequately iodized salt $(15+$ of particles per million). The rates are 52\% in Sugd, 32\% in Dushanbe, and less than 3\% in GBAO, RRS, and Khatlon.

Access to safe drinking water is $93 \%$ for urban population and $47 \%$ for rural population. Among the regions, GBAO ranks the lowest with $28 \%$ of the population having access to water taken from safe source. 


\section{[Translation from Russian]}

No. 243-(23.1/12.3)

June 1, 2004

Mr. Rodrigo Rato

The Managing Director

The International Monetary Fund (IMF)

Washington D.C., USA

Dear Mr. Rodrigo Rato,

First of all, allow me to congratulate you upon your appointment as the Managing Director of the International Monetary Fund and to wish you every success in such a responsible post.

In my turn, further to our submission of first annual progress report on the implementation of the PRSP, on April 5, 2004, I would like to provide an update to the macroeconomic framework of the country's economy.

Although the report was completed in March 2004, the macroeconomic scenarios were prepared considerably earlier to enable consultations with stakeholders.

As changes in the structure of an economy and commodity prices are occurring rapidly, we have updated our growth and budget projections (Table 5).

In this update, we have revised the GDP growth rate upwards, reflecting recent economic developments. At the same time, there are smaller increases in revenue and expenditure in relation to GDP.

We do not consider that these revised projections significantly change other parts of the report.

In addition, I would like to inform you that we give our consent to the publication of the first progress report of the PRSP, the joint staff assessment of that report, and this update letter.

Sincerely yours,

/s/

F. Kholboboev

State Economic Advisor

To the President of the Republic of Tajikistan 


\begin{tabular}{|c|c|c|c|}
\hline & \multicolumn{3}{|c|}{ Forecasts } \\
\hline & 2004 & 2005 & 2006 \\
\hline GDP (in millions of somoni) & 5,750 & 6,461 & 7,122 \\
\hline Real GDP growth (in percent) & 8.5 & 7.5 & 6.0 \\
\hline Inflation (end-of-period, in percent) & 7.0 & 5.0 & 5.0 \\
\hline \multicolumn{4}{|c|}{ General Government Finances (in percent of GDP) } \\
\hline Total Revenue & 17.7 & 17.9 & 18.2 \\
\hline Employers' contributions to the SPF & 1.8 & 1.8 & 1.8 \\
\hline VAT & 5.3 & 5.0 & 5.0 \\
\hline Excise tax & 0.8 & 0.9 & 0.9 \\
\hline Sales tax (cotton, aluminum) & 1.9 & 1.7 & 1.5 \\
\hline Income and profit taxes & 1.4 & 1.4 & 1.5 \\
\hline Other tax & 4.1 & 4.8 & 5.0 \\
\hline Non-Tax & 2.4 & 2.4 & 2.5 \\
\hline Total Expenditures minus net lending 1/ & 18.1 & 18.4 & 18.2 \\
\hline Education & 3.1 & 3.3 & 3.4 \\
\hline Health & 1.4 & 1.6 & 1.6 \\
\hline Social Protection & 2.0 & 2.2 & 2.2 \\
\hline Management, defence and law \& order & 4.4 & 4.4 & 4.3 \\
\hline Economic sectors & 2.1 & 2.1 & 2.0 \\
\hline Other & 5.1 & 4.8 & 4.7 \\
\hline Deficit $1 /$ & -0.4 & -0.5 & 0.0 \\
\hline Externally financed PIP & 3.0 & 3.0 & 3.0 \\
\hline External debt $2 /$ & 61.0 & 59.4 & 57.7 \\
\hline
\end{tabular}

Source: Ministry of Finance.

1/ Excludes the externally-financed Public Investment Program (PIP).

2/ Assuming full disbursement of PIP projections. 